UNIVERSIDADE DE SÃO PAULO

\author{
PROGRAMA DE PÓS-GRADUAÇÃO EM \\ INTEGRAÇÃO DA AMÉRICA LATINA
}

MARCELO DA SILVA SOBRINO

MIGRAÇÕES E SEGURANÇA: A FRONTEIRA ESTADOS UNIDOSMÉXICO E A DINÂMICA DA SECURITIZAÇÃO DA QUESTÃO MIGRATÓRIA 
MARCELO DA SILVA SOBRINO

\section{MIGRAÇÕES E SEGURANÇA: A FRONTEIRA ESTADOS UNIDOS- MÉXICO E A DINÂMICA DA SECURITIZAÇÃO DA QUESTÃO MIGRATÓRIA}

Dissertação apresentada ao Programa de Pósgraduação em Integração da América Latina da Universidade de São Paulo (PROLAM/USP), como requisito para obtenção do título de Mestre em Integração da América Latina

Orientador: Professor Dr. André Roberto Martin 
FOLHA DE APROVAÇÃO

Marcelo da Silva Sobrino

Migrações e Segurança: a Fronteira Estados Unidos-México e a Dinâmica da Securitização da Questão Migratória

Dissertação apresentada ao Programa de Pós-graduação em Integração da América Latina da Universidade de São Paulo (PROLAM/USP), como requisito para obtenção do título de Mestre em Integração da América Latina.

Aprovado em:

Banca examinadora

Prof. Dr.

Instituição: Assinatura:

Prof. Dr.

Instituição: Assinatura:

Prof. Dr. Instituição: Assinatura: 
A meus pais,

José Sobrino Salgado e Elizia da Silva Sobrino com amor incondicional. 


\section{AGRADECIMENTOS}

Ao Prof. Dr. Leonel Itaussu Almeida Mello (in memoriam), meu mestre e orientador, por ter acreditado em mim, pela amizade, compreensão, paciência e, sobretudo, pelos ensinamentos e firme condução da pesquisa. Um verdadeiro exemplo - de vida e de intelectual - a ser seguido.

Ao Prof. Dr. André Roberto Martin, meu orientador, por ter me estendido a mão em um momento tão difícil; pela amizade, incentivo e pela preciosa orientação.

Ao Prof. Dr. Flávio Rocha de Oliveira, pelos ensinamentos, companheirismo, pelas oportunidades a mim proporcionadas e por seu inconteste apoio.

Ao Prof. Dr. Antonio Roberto Espinosa, pelo apoio e pelas valiosíssimas críticas e comentários quando da banca de qualificação.

À Profa. Dra. Yara Maria Martins Nicolau Milan, por tudo o que ensinou e fez por mim. Não tenho palavras para expressar minha gratidão.

Aos meus amigos e colegas da Escola Pós-Graduada da Fundação Escola de Sociologia e Política de São Paulo (EPG-FESP/SP).

Aos meus companheiros de jornada do PROLAM.

Aos meus alunos, sem os quais boa parte disso não teria sentido. 


\section{AGRADECIMENTOS ESPECIAIS}

A meus queridos pais, José Sobrino Salgado e Elizia da Silva Sobrino. Palavras nunca serão suficientes para expressar todo o meu amor, admiração, respeito e gratidão. Obrigado por tudo! À minha irmã, Daniela da Silva Sobrino - te amo! - pelo amor, carinho, paciência e por todo o apoio, sempre e inconteste. Sem vocês, eu sequer teria dado o primeiro passo...

À Verônica Jorge Santos, meu grande amor, pelo carinho, companheirismo e constante apoio. Você me mostrou que sim, é possível!

À Sílvia Regina Cavani Jorge Santos, pelo carinho, incentivo e atenção mais que especial. A Paulo Sérgio Santos, pelo estímulo, efetivo apoio e constante incentivo. A Mauro Jorge Santos, pelos conselhos, incentivo e preciosa companhia.

A todos vocês, o meu muito obrigado! 
"It was the best of times, it was the worst of times, it was the age of wisdom, it was the age of foolishness, it was the epoch of belief, it was the epoch of incredulity, it was the season of Light, it was the season of Darkness, it was the spring of hope, it was the winter of despair, we had everything before us, we had nothing before us, we were all going direct to Heaven, we were all going direct the other way..."

(Charles Dickens, A Tale of Two Cities).

“... al norte del río grande,

al sur del río bravo,

plumas emblemáticas de cada hazaña, cada batalla, cada nombre, cada memoria, cada derrota, cada triunfo, cada color

al norte del río grande,

al sur del río bravo,

que vuelen las palavras

pobre México,

pobre Estados Unidos,

tan lejos de Dios,

tan cerca el uno del otro"

(Carlos Fuentes, La Frontera de Cristal). 


\section{RESUMO}

SOBRINO, Marcelo da Silva. Migrações e Segurança: a Fronteira Estados UnidosMéxico e a Dinâmica da Securitização da Questão Migratória. 2016. 109 f. Dissertação (Mestrado) - Programa de Pós-graduação em Integração da América Latina da Universidade de São Paulo (PROLAM/USP), 2016.

A questão da securitização das migrações, enquanto problema de pesquisa, surgiu no contexto dos debates acerca da ampliação do conceito de segurança que tomou corpo no pós-Guerra Fria, dadas as grandes transformações que se sucederam a este evento-chave da política internacional contemporânea. No caso da fronteira Estados Unidos-México, este é um fenômeno que, de fato, pode ser observado desde o final dos anos 1970, tendo atingido o seu ápice no pós-Onze de Setembro. A partir deste cenário, o objetivo do presente trabalho de pesquisa é o de analisar a dinâmica da securitização dos fluxos migratórios no contexto da fronteira Estados Unidos-México; em especial, o caso dos imigrantes indocumentados, que são o alvo primário das práticas securitizantes. Para tanto, será empregado o ferramental teórico desenvolvido pela Escola de Copenhague; em especial, a teoria de securitização e o conceito de segurança societal. Ao final, buscar-se-á problematizar a questão, tendo-se em vista as reflexões desenvolvidas ao longo do trabalho, bem como avaliar as possibilidades de desenvolvimento da mesma, assumindo como pressuposto que o ideal seria a progressiva desecuritização do tema e a adoção de uma política migratória, por parte dos EUA, mais moderna, pragmática e humana, e que a questão da segurança fosse tratada separadamente, considerando a questão migratória mas sem elevá-la ao nível do excepcional, que é o que justifica a securitização, a qual tem um enorme potencial para gerar, nesta seara, graves consequências de caráter humanitário.

Palavras-chave: Securitização; segurança societal; migrações; fronteira Estados UnidosMéxico. 


\begin{abstract}
SOBRINO, Marcelo da Silva. Migrations and Security: the United States-Mexico border and the Dynamics of the Securitization of Migration's Issue. 2016. 109 p. Dissertation (Master's Degree) - Programa de Pós-graduação em Integração da América Latina da Universidade de São Paulo (PROLAM/USP), 2016.
\end{abstract}

The securitization of migration's issue as a research problem has arisen in the context of the debates on broadening the concept of security in the post-Cold War era, taking in consideration the significant changes that followed this key-event in the contemporary international politics. In the case of the United States-Mexico border, this is a phenomenon that, in fact, can be observed since the late 1970s, having reached its apex in the post-09/11. In this scenario, the aim of the current research work is to assess the dynamics of the securitization of migrations' flows in the context of the United States-Mexico border; mainly, the case of the undocumented immigrants, who are the primary targets of the securitization practices. Theoretical methodology developed by the Copenhagen School; mainly the securitization theory and the concept of societal security, will be utilized as assessment tools in the current research work. At the end, the objective will be to problematize the question, taking in consideration the reflections raised during the research work, as well as evaluating the development possibilities, assuming as an ideal scenario the progressive desecuritization and the adoption of a more modern, pragmatic, and human migratory policy by the United States; and that the security issue be treated separately, considering the migratory issue but without elevating it to the exceptional level, which justifies the securitization, and has an enormous potential of generating severe humanitarian consequences in this field.

Keywords: Securitization; societal security; migrations; United States-Mexico border. 


\section{RESUMEN}

SOBRINO, Marcelo da Silva. Migraciones y Seguridad: la frontera Estados UnidosMéxico y la Dinámica da Securitización de la Cuestión Migratoria. 2016. 109 f. Disertación de Maestría - Programa de Pós-graduação em Integração da América Latina da Universidade de São Paulo (PROLAM/USP), 2016.

El tema de la securitización de las migraciones, como problema científico, surgió en el contexto de los debates acerca de la ampliación del concepto de seguridad que tomo forma en el escenario pos-Guerra Fría, dadas las grandes transformaciones que se sucedieron a este evento-clave de la política internacional contemporánea. En el caso de la frontera Estados Unidos-México, este es un fenómeno que, de hecho, puede ser observado desde el final de los años 1970, alcanzando su punto máximo en el pos Once-Septiembre. A partir de ese escenario, el objetivo del presente proyecto de investigación é analizar la dinámica de la securitización de los flujos migratorios en el contexto de la frontera Estados Unidos-México; en especial el caso de los inmigrantes indocumentados, que son el objetivo primario de las practicas securitizantes. Para tanto, se va a emplear el herramental teórico desarrollado por la Escuela de Copenhague; en especial, la teoría de securitización e el concepto de seguridad societal. Al final, se va a buscar problematizar el tema, llevando en cuenta las reflexiones desarrolladas a lo largo del proyecto, así como evaluar las posibilidades de desarrollo, asumiendo como presupuesto que lo ideal sería la desecuritización progresiva del tema y la adopción por parte de Estados Unidos de una política migratoria más moderna, pragmática y humana, de manera que el tema de la seguridad fuera tratado separadamente, teniendo en cuenta el tema migratorio, pero sin elevarlo a nivel excepcional, lo que justifica la securitización, la cual tiene un enorme potencial para generar graves consecuencias de carácter humanitario en el área.

Palabras clave: Securitización; seguridad societal; migraciones; frontera Estados UnidosMéxico. 


\section{LISTA DE SIGLAS E ABREVIATURAS}

AEDPA

CAST

CBP

CIA

CIS

COPRI

DHS

ICE

IIRIRA

IISS

LIC

NAFTA

NATO / OTAN

ONG

RAND

$\mathrm{UN} / \mathrm{ONU}$

UNPD / PNUD

US / USA / EUA

WASP

WTO / OMC
Antiterrorism and Effective Death Penalty Act

Centre for Advanced Security Theory

US Customs and Border Protection

Central Intelligence Agency

US Bureau of Citizenship and Immigration Services

Conflict and Peace Research Institute

Department of Homeland Security

US Immigration and Customs Enforcement

Illegal Immigration Reform and Individual Responsibility Act

International Institute for Strategic Studies

Low-Intensity Conflict

North America Free Trade Agreement

North Atlantic Treaty Organization / Organização do Tratado do Atlântico Norte

Organização não-governamental

Research and Development (US think tank)

United Nations / Organização das Nações Unidas

United Nations Development Programme / Programa das Nações Unidas para o Desenvolvimento

United States / United States of America / Estados Unidos da América White, Anglo-Saxon and Protestant

World Trade Organization / Organização Mundial do Comércio 


\section{SUMÁRIO}

INTRODUÇÃO

\section{CAPÍTULO I - Os Estudos de Segurança Internacional e a Contribuição} da Escola de Copenhague

1.1 Os Estudos de Segurança Internacional em perspectiva histórica

1.2 A Escola de Copenhague

1.2.1 A teoria de securitização

1.2.2 Setores e segurança societal

1.2.3 Complexos regionais de segurança

1.2.3.1 O complexo regional de segurança da América do Norte 26

1.2.4 Crítica e debate

CAPÍTULO II - A Fronteira Estados Unidos-México e o Choque de Narrativas

2.1 Construindo a fronteira sul

2.2 Construindo a identidade norte-americana

2.2.1 A ideia de nação

2.2.2 A narrativa da nação norte-americana

2.3 Construindo a diferença 
CAPÍTULO IV - A Escalada da Securitização e suas Consequências

4.1 Civilização vs. Barbárie: de volta ao início 81

4.1.1 Nativismo e vigilantismo no ocaso da Razão 90

4.1.2 Novos tempos, velhos inimigos: a fronteira e o estado de exceção 95

CONSIDERAÇÕES FINAIS 98

REFERÊNCIAS BIBLIOGRÁFICAS 102 


\section{Introdução}

As fronteiras políticas, expressão mais bem acabada do alcance territorial do poder soberano do Estado, caracterizam-se, nos dias atuais, por um paradoxo aparentemente irresolúvel: elas são - ao mesmo tempo - cada vez mais irrelevantes para os fluxos de bens, serviços e capitais, e cada vez mais relevantes para obstar o fluxo de pessoas que buscam trabalho ou refúgio em Estados que não os seus. Por um lado, o discurso triunfante da globalização, do "fim da história" (F. Fukuyama) e do "mundo sem fronteiras" (K. Ohmae); por outro, pesados investimentos na construção de infraestrutura física, tais como muros, cercas e afins, equipamentos de vigilância e controle, treinamento e deslocamento de um contingente cada vez maior de forças policiais e militares para as regiões de fronteira, com o intuito de evitar, a qualquer custo (humanitário, inclusive, em vários casos) que imigrantes sem prévia autorização legal (“indocumentados”) consigam adentrar ao território do respectivo Estado, mormente em busca de trabalho e condições de vida minimamente dignas. Isso sem mencionar o modo como os refugiados costumam ser tratados ao longo das faixas de fronteira. Do pós-Guerra Fria em diante, a construção de novas fronteiras e o reforço contínuo das já existentes é uma realidade inconteste. Ademais, por razões de segurança - notadamente no pós-Onze de Setembro - políticas que visam estabelecer um sistema cada vez mais rígido e efetivo de controle sobre as fronteiras tem sido a norma.

O debate sobre a segurança internacional, por sua vez, passou por uma grande reformulação, a partir do pós-Guerra Fria, resultando em duas visões distintas: uma denominada "tradicionalista", tributária das tradições que orientaram os estudos nesta seara durante toda a Guerra Fria, e uma denominada "abrangente" que, a despeito de ter suas raízes nos anos 1980, ganhou destaque e se estruturou de fato no pós-Guerra Fria. Esta visão "abrangente" buscou, desde o início, repensar o conceito de segurança e sua aplicação no cenário internacional, tendo logrado construir uma visão multidimensional do fenômeno da segurança, a qual vai além do tradicional setor militar, incorporando também, por exemplo, o ambiental e o econômico, cujas discussões remontam aos anos 1970. Várias escolas de pensamento se constituíram com o fito de desenvolver o tema sob esta nova agenda, merecendo destaque, aqui, a Escola de Copenhague, que fornecerá o ferramental teórico julgado como mais apropriado para o tratamento do tema deste trabalho; notadamente, a teoria de securitização e o conceito de segurança societal. 
Por fim, o fenômeno das migrações internacionais, que ganhou densidade e maior visibilidade com o advento da globalização, nas últimas décadas, constitui o terceiro eixo estruturante deste trabalho, dadas suas ligações com a temática das fronteiras e da segurança.

Ora, é a partir deste pano de fundo que se constituiu o tema do projeto de pesquisa que resultou nesta dissertação, a saber: as relações entre o fenômeno migratório e a segurança internacional. Mais precisamente, esta dissertação tem como tema a questão da dinâmica da securitização dos fluxos migratórios na região da fronteira entre os Estados Unidos e o México, do início da militarização da fronteira sob a égide da Doutrina do LIC (1978) até o ano de 2009 (final do governo de George W. Bush). Tais fluxos migratórios, vale dizer, são os compostos por imigrantes indocumentados ("ilegais"), que tentam cruzar a fronteira em busca de melhores condições de vida. Estes "indocumentados" serão o alvo das políticas de segurança e do processo de securitização que se materializam ao longo de toda a região da fronteira; não raro, com gravíssimas consequências de caráter humano.

O problema de pesquisa a ser enfrentado é o seguinte: quais são as condicionantes do processo de securitização no caso em tela? Vale dizer, como se deu a securitização? Quais são os fatores, as forças e atores que, em seus respectivos níveis, interagiram (e interagem) no sentido de promover a securitização da questão migratória na região da fronteira Estados Unidos-México e no recorte temporal selecionado (1978/2009)?

A hipótese adotada vai no sentido de que tal processo tem profundas raízes históricas e, a despeito de ser formalmente ancorado na questão da segurança societal, possui outros elementos que o constituíram historicamente (racismo, por exemplo). Deste modo, a fronteira é o lugar por excelência da construcão da significação e das identidades; do "nós" e "eles" e, no caso da fronteira Estados Unidos-México, da "civilização" e "barbárie". Em matéria de segurança, a fronteira forma a primeira linha defensiva e, em termos de segurança societal, é a grande barreira destinada a conter os fluxos migratórios que, pouco a pouco - segundo a (suposta) justificativa apresentada - vão colocando em risco a identidade nacional, tomada como homogênea e sob constante ameaça do "estrangeiro".

Para discutir tal assunto, a dissertação foi planejada de modo a conter quatro capítulos. O primeiro capítulo será destinado a uma breve revisão acerca da evolução dos Estudos de Segurança Internacional ${ }^{1}$, buscando, ao final, situar o estado atual da disciplina. Na sequência,

\footnotetext{
${ }^{1}$ Vale notar que inexiste consenso em relação ao nome exato do campo de estudos. Alguns o denominam de "Estudos de Segurança" (Security Studies), outros de "Estudos de Segurança Internacional" (International Security Studies), e outros de modo mais impreciso ainda. Por conta disso, será mantida a notação original dos autores trabalhados, seja ela qual for.
} 
será enfatizada a Escola de Copenhague, seu arcabouço teórico e contribuição para a evolução da disciplina. É nesse momento que serão introduzidos e analisados a teoria de securitização e o conceito de segurança societal, uma vez que servirão de suporte teórico para o estudo de caso a ser desenvolvido.

O segundo capítulo tratará da fronteira Estados Unidos-México e das narrativas que informam tanto a base identitária dos EUA (a "narrativa da nação") quanto a que informa a construção social do "outro" (no caso, os latinos, via de regra tomados simplesmente como "mexicanos" - o grande alvo da securitização), que é a narrativa da "ameaça latina", presente na base de todos os discursos, práticas sociais e políticas de viés restritivo, quando não abertamente racistas e xenófobas.

Já o terceiro capítulo, por sua vez, terá como foco a construção histórica dos mexicanos enquanto verdadeiros "inimigos", partindo dos primeiros dias do estabelecimento da fronteira até a atualidade, quando foram definitivamente classificados (os indocumentados, vale dizer) como uma "ameaça à segurança nacional", o que demanda a tomada de medidas excepcionais para contê-los do outro lado da fronteira e evitar, a todo custo, que adentrem "ilegalmente" no território dos EUA.

Por fim, no quarto e último capítulo será analisada a situação constituída a partir do Onze de Setembro, marcada por uma escalada no processo de securitização que tem como base a verdadeira paranoia em matéria de segurança que se instalou nos EUA por conta dos ataques, e dois fenômenos complementares: o ressurgimento de grupos nativistas e de "vigilantes", com livre atuação ao longo da faixa de fronteira, e a estabelecimento do estado de exceção, em caráter permanente, também ao longo da faixa de fronteira (mas não se limitando à ela), afastando todo um conjunto de direitos e liberdades civis historicamente constituídos e conquistados por conta da alegada necessidade de serem adotadas medidas de caráter excepcional para a devida proteção e guarda da fronteira e, por extensão, dos EUA.

Ao final do trabalho que, em nenhum momento, terá a tola pretensão de "esgotar o assunto" mas, tão somente, fazer uma pequena reflexão sobre tão complexo tema, será feita uma síntese dos principais pontos discutidos, com o intuito de tecer alguns comentários adicionais para, por fim, problematizar a questão examinada, que é naturalmente densa e permeada de variáveis que dificultam a análise, levantando novas questões e buscando apontar as futuras tendências relacionadas ao tema. 


\section{Capítulo I - Os Estudos de Segurança Internacional e a Contribuição da Escola de Copenhague}

"Security is thus a self-referential practice, because it is in this practice that the issue becomes a security issue - not necessarily because a real existential threat exists but because the issue is presented as such a threat"

(BUZAN et al., 1998: 24)

\subsection{Os Estudos de Segurança Internacional em perspectiva histórica}

A preocupação com a segurança tem sido um dos pilares estruturantes da existência humana desde o seu início. Todas as sociedades, de ontem e de hoje, sempre se pautaram pela defesa da vida de seus integrantes e de suas estruturas, buscando ao mesmo tempo proteger-se contra ameaças externas e internas, administrar os conflitos e, fundamentalmente, perpetuarse no tempo. Não seria à toa que o tema da guerra e paz tenha ocupado boa parte do tempo das lideranças políticas desde as primeiras civilizações. Os sumérios, por exemplo, já contavam com exércitos regulares; a Grécia de Tucídides fazia das frequentes guerras a sua própria história; e os romanos estenderam seu Imperium a limites nunca antes imaginados. Contudo, foi somente a partir do surgimento do Estado moderno (século XVII) que a ideia de segurança, bem como sua práxis, assumiu contornos político-normativos bem definidos, ou seja, a partir de então o Estado territorial soberano passaria a ter o dever fundamental de garantir a segurança de seus súditos.

Para Thomas Hobbes (2008: 147-148), a segurança dos indivíduos contra seus próprios pares, bem como a segurança da coletividade contra ameaças externas só seria possível através de um "pacto de cada homem com todos os homens", o qual daria ensejo ao "Deus mortal", ao Leviatã, única entidade capaz de garantir a paz e a defesa comuns. Contudo, se no seu entender essa era uma possível solução para a Guerra Civil Inglesa (século XVII), ela não resolvia a questão da violência organizada entre os Leviatãs. Dito de outro modo, com a criação do Leviatã o "estado de natureza" desapareceria no plano interno (estatal), mas se fortaleceria no plano externo, arena na qual os Leviatãs estariam livres para lutar pelo poder supremo (DERIAN, 1995: 30).

Com o final da Guerra dos Trinta Anos na Europa (1618-48) e a instituição da Paz de Westphalia (1648), inaugurou-se uma nova ordem europeia, fundada no princípio da 
soberania estatal, elemento-chave na consolidação do nascente sistema interestatal, cuja estabilidade estaria ancorada no que viria a ser conhecido como "equilíbrio de poder". De fato, o grande legado da ordem westphaliana persiste até os dias atuais, dados que o sistema segue sendo estatocêntrico mas não eurocêntrico (ainda que novos e importantes atores tenham surgido), a soberania é um valor fundamental (a despeito das diversas interpretações sobre a natureza e o alcance do poder soberano), e o equilíbrio de poder (ou balança de poder) é verdadeira instituição da política internacional, em que pese o surgimento de sofisticados mecanismos de governança, de inspiração wilsoniana, ao longo do último século.

Contudo, ainda que questões relativas à segurança tenham sido uma constante na história da humanidade, foi apenas em meados do século XX que este tema assumiu contornos acadêmicos definidos. De acordo com Stephen Walt (1991: 213-214), em seu muito citado artigo sobre a "renascença" dos estudos de segurança a partir da metade dos anos 1970, até a Segunda Guerra Mundial (1939-45) esse era um campo de interesse e estudo restrito aos círculos diplomáticos e militares, com raras exceções. De fato, até então havia uma espécie de monopólio do conhecimento, por parte desses setores, no que tange ao estudo e planejamento de questões de segurança. Entretanto, dois fatores foram determinantes para que um ciclo de abertura, reforma e posterior expansão da disciplina e de sua comunidade epistêmica ocorresse a partir do imediato após-guerra (1945): o surgimento das armas nucleares e a ascensão dos Estados Unidos à condição de superpotência mundial.

No caso das armas nucleares, Walt (1991: 214) pondera que o seu surgimento lançou várias questões aos estudiosos e estrategistas da época, civis e militares, sendo a principal delas a que indaga como os Estados poderiam usar as armas de destruição em massa como instrumento de política, dada a possibilidade de também serem atingidos por elas. Ora, considerando o impacto que o fator nuclear gerou no sistema internacional, não é de se estranhar que tenha determinado quase que toda a agenda de pesquisa durante a "era de ouro" (1955-1965) dos estudos de segurança.

Já no caso da centralidade dos EUA no sistema internacional, é sabido que, embora tenham feito sua primeira aparição no cenário internacional em 1917, quando declararam guerra à Alemanha, foi apenas ao final da $2^{\mathrm{a}}$ Guerra que assumiram a condição de superpotência, e logo identificariam na União Soviética todos os recursos de poder que a posicionariam como sua grande rival, rivalidade esta que ditaria os contornos da Guerra Fria (1947-89). Kissinger (1994) salienta o impacto que o "Longo Telegrama" do embaixador norte-americano em Moscou, George Kennan (o "Mr. X"), provocou primeiro na cúpula do poder em Washington e, depois, na política externa norte-americana. Em síntese, para Kennan, 
a Rússia sempre foi uma nação expansionista - desde o tempo dos czares -, e agora, sob o "dogma" do comunismo, ela se tornara o grande inimigo ideológico, político e estratégico não apenas dos EUA, mas de todo o Ocidente $^{2}$. Ora, para garantir a sua própria segurança, era necessário que derrotasse os Estados Unidos. Consequentemente, dada a ferocidade ideológica do inimigo, nenhum mecanismo diplomático convencional seria capaz de gerar um resultado adequado, devendo-se adotar o quanto antes a política do containment (contenção) para garantir a segurança dos EUA e de seus aliados.

Portanto, assim como a geopolítica surgiu na Suécia a partir dos esforços de Rudolf Kjéllen, tendo Friedrich Ratzel a empregado para compreender e equacionar os problemas advindos da unificação alemã e, fundamentalmente, pensar a "questão nacional", os estudos de segurança nasceram em um Estado às voltas com seu recém-adquirido poderio global, e que precisava rapidamente acomodar sua posição, planejar o futuro e enfrentar grandes desafios, quais sejam, a "liderança do mundo ocidental" e a defesa de seus valores e interesses vis-à-vis a outra superpotência do pós $2^{\mathrm{a}}$ Guerra, a União Soviética.

Interdisciplinar por excelência, a jovem disciplina dos estudos de segurança surgiu com um objetivo teórico bem definido: gerar conhecimento acerca das armas nucleares e seu papel nas relações internacionais ${ }^{3}$. Por conta disso, inúmeros estudos surgiram nesse período, devendo-se notar o proeminente papel de um think tank norte-americano denominado RAND, responsável por boa parte das inovadoras pesquisas da época. Amplo acesso à informação, um ambiente institucional bem estruturado e, fundamentalmente, suas estreitas relações com o Departamento de Defesa dos EUA foram as razões de sua prolífica e bem-sucedida produção acadêmica.

Barry Buzan e Lene Hansen (2010), em obra recente mas que já se tornou referência obrigatória no que tange ao estudo da evolução dos estudos de segurança internacional, destacam que o RAND, por exemplo, produziu conhecimento inovador no campo da teoria dos jogos e da teoria da dissuasão (deterrence), sendo que muito da sua produção acadêmica não apenas influenciou a formatação da política externa de segurança norte-americana mas foi de fato implementada em sua quase totalidade. Sua contraparte britânica, o International Institute for Strategic Studies (IISS), fundado em Londres, 1958, também desempenhou um papel proeminente na chamada "era de ouro" da disciplina. Os Adelphi Papers, por exemplo,

\footnotetext{
2 "Ocidente“, aqui, significa o espaço geográfico sob a tutela militar da OTAN.

${ }^{3}$ Formalmente, as Relações Internacionais, enquanto área do conhecimento, surgiram em 1919, na Universidade de Aberystwyth (Reino Unido), através da instituição da $1^{\mathrm{a}}$ cátedra de política internacional do mundo (Cátedra Professor Woodrow Wilson). Já a disciplina dos estudos de segurança, como já dito, tem origem norte-americana, sendo considerada por muitos o principal ramo das Relações Internacionais. Fica claro, portanto, o papel da "aliança transatlântica" na formatação da disciplina e de sua agenda.
} 
principal publicação do IISS até hoje, contribuíram e seguem contribuindo com pesquisas originais e inovadoras no campo da segurança; particularmente, no campo dos chamados "estudos estratégicos", sub-ramo dominante dos "estudos de segurança" ao menos até o final da Guerra Fria.

Entretanto, em meados da década de 1960 o campo dos estudos de segurança entrou em declínio, por conta de fatores tais como, dentre outros, o esgotamento um tanto precoce do seu programa inicial de pesquisa, a Guerra do Vietnã (1961-1975), e o advento da détente entre os Estados Unidos e a União Soviética (WALT, 1991: 215-216).

O esgotamento do programa de pesquisa se deu porque, se de um lado o paradigma da dissuasão racional era suficiente para a compreensão da maioria dos problemas da época, por outro haviam novas e prementes questões as quais ele não dava conta, o que exigia o desenvolvimento de novos e mais sofisticados modelos e teorias. Já a Guerra do Vietnã (1961-75), além de tornar o campo de estudo pouco atraente para os jovens universitários norte-americanos (para dizer o mínimo), na sua quase totalidade contrários à guerra, ainda pôs em cheque a validade teórica de vários trabalhos e pesquisas iniciais, uma vez que os EUA não conseguiam aplicar com sucesso, na prática, o arcabouço teórico previamente desenvolvido. Por fim, a détente foi o golpe de misericórdia nos estudos de segurança dado que, a partir de então, boa parte de academia optou por deixar de lado as questões políticomilitares relacionadas à guerra e ao uso da força e passou a se dedicar as questões econômicocomerciais, enfatizando sua importância no cenário da época. Estes seriam os tempos do desenvolvimento do paradigma da interdependência, por exemplo, e da ascensão dos estudos de Economia Política Internacional.

Todavia, se uma combinação de fatores levou o campo de estudos a um período de declínio, uma nova combinação acabou por gerar a renovação do campo, em meados dos anos 1970. Basicamente, a "renascença" pode ser entendida a partir de duas grandes condicionantes (WALT, 1991): o fim da Guerra do Vietnã (1961-1975) e o colapso da détente. O final da Guerra (1975) fez com que o campo se tornasse novamente atraente, uma vez que os jovens pesquisadores agora tinham interesse em aprender com os erros do passado. Esse revival acadêmico somou forças com o fim da détente (1991), o qual trouxe à baila mais uma vez a questão da segurança nacional na opinião pública e na academia, dado que as tensões internacionais ganharam novo ímpeto. Secundariamente, um aumento na qualidade e quantidade de informações disponíveis aos pesquisadores, um aumento nos programas de financiamento de pesquisa, liderados pela Ford Foundation, e um aumento nos periódicos especializados, com destaque para a fundação da revista International Security (principal 
publicação do campo até hoje) contribuíram para consolidar o renascimento do campo de estudos em meados dos anos 1970.

Ante o exposto, fica claro, na análise de Stephen Walt (1991), o papel crucial desempenhado pela "política das grandes potências" (Guerra Fria), pelos eventos (Guerra do Vietnã), pela tecnologia (armas nucleares) e pelas instituições acadêmicas e de financiamento à pesquisa (RAND, IISS; Ford Foundation, MacArthur Foundation). Ora, será exatamente a partir da identificação e do estudo dessas "forças motrizes", nos termos propostos por Barry Buzan e Lene Hansen (2010), e dos seus respectivos impactos nas relações internacionais, de modo geral, e nos estudos de segurança internacional, em particular, que estes autores elaborarão o melhor e mais completo estudo sobre a evolução dos estudos de segurança.

Para estes autores, a trajetória da disciplina contemplou quatro distintas fases, assim definidas: i) o período do imediato após $2^{\mathrm{a}}$ Guerra; ii) a Guerra Fria (com suas fases específicas); iii) o pós-Guerra Fria; e iv) o pós-Onze de Setembro. Ademais, estas fases foram moldadas e impulsionadas por cinco forças motrizes essenciais, a saber: i) política das grandes potências; ii) eventos; iii) tecnologia; iv) debates acadêmicos; e v) institucionalização (BUZAN; HANSEN, 2010).

Apoiados nesta estrutura, os autores ponderam que, enquanto campo de estudos autônomo, a disciplina de segurança internacional tem suas raízes nas décadas de 1940/1950, a partir da intersecção entre a expertise militar e as Ciências Sociais. Dada a frutífera colaboração entre especialistas civis (físicos, cientistas sociais, etc.) e militares durante a $2^{\circ}$ Guerra, a partir de então seria possível que civis também se dedicassem ao tema da segurança (BUZAN; HANSEN, 2010: 66). Logo, nascia ali um novo ramo do conhecimento, que encontraria seu nicho posteriormente como a principal (para muitos) sub-área das Relações Internacionais, e que viria a dar uma contribuição inestimável a um campo que, desde sempre, era dominado quase que exclusivamente por especialistas militares. Se o estudo da guerra, da estratégia, da geopolítica, da história militar, da história diplomática, etc., sempre foi praticamente restrito aos militares e afins, doravante os civis (acadêmicos, notadamente) poderiam, também, dar sua contribuição para o avanço do campo que, desde o início, seria tomado como praticamente sinônimo dos Estudos Estratégicos, e assim o seria por longo tempo.

Tal como Walt (1991), Buzan e Hansen (2010) também consideram que as duas grandes forças motrizes que impulsionaram o desenvolvimento do campo logo no seu início foram a política das grandes potências (Guerra Fria) e a tecnologia (revolução nuclear). A Guerra Fria, além de ajudar a moldar os conceitos de bipolaridade e de superpotência, serviu 
também como estrutura para todo o desenvolvimento teórico da época: teoria da dissuasão, da contenção, corrida armamentista, controle de armas, etc., tudo dentro dos limites postos por um sistema internacional bipolar. Ademais, a Guerra Fria consolidou, nos Estados Unidos, a imagem da União Soviética como o grande adversário, cuja mera presença ameaçava a sua própria existência. Em um cenário mundial à sombra das armas nucleares, a busca permanente por segurança de caráter estratégico-militar era imperiosa e, para tanto, a contribuição do nascente campo dos Estudos Estratégicos foi, de fato, primorosa.

Aliás, no caso das armas nucleares, a dupla de autores entende que elas geraram um imperativo estratégico que está no centro dos estudos de segurança até hoje, a despeito dos avanços e da expansão do campo. À medida que a tecnologia avançava - e avançava de modo muito rápido - no final dos anos 1970 as duas superpotências já acumulavam dezenas de milhares de ogivas nucleares, e todos os sistemas associados de armazenamento, transporte, lançamento, defesas, radares, etc., estavam maduros e equiparados. Em termos teóricos, para lidar com a questão nuclear, a teoria da dissuasão ganhou logo um adjetivo e, assim, a teoria da dissuasão nuclear assumiu o centro dos debates, dividindo espaço com a teoria da contenção expandida, contenção mínima, contenção máxima, dentre outras.

Em que pese o fato do cenário internacional ter sido dominado pela bipolaridade e pelas armas nucleares, Buzan e Hansen (2010: 83-87) ponderam que os eventos, enquanto força motriz, também desempenharam um papel relevante na evolução da disciplina. Notadamente, o bloqueio de Berlim Ocidental (1948/1949), cujo desdobramento seria a construção do Muro de Berlim (1961) e a Guerra da Coreia (1950/1953) funcionaram como eventos constitutivos da disciplina, reforçando a visão ocidental de uma União Soviética expansionista e, por decorrência, a necessidade da política de contenção. Já a crise dos mísseis em Cuba (1962) foi o maior e mais impactante evento no que tange a evolução da disciplina, tendo gerado uma enorme quantidade de literatura, além de ter ampliado o espectro do campo, que agora também endereçaria questões tais como o gerenciamento de crises, a escalada e melhores e mais confiáveis meios de comunicação entre Washington e Moscou.

Já a Guerra do Vietnã (1961-1975), curiosamente, gerou pouco impacto na disciplina, provavelmente por ter sido vista apenas como um reflexo da política de contenção dos EUA e do medo do "efeito dominó". A despeito disso, ela deu ensejo a uma outra literatura ("subliteratura", nos termos de Buzan e Hansen), focada na guerra de guerrilha e contra-insurgência, temas que estavam fora do foco dos Estudos Estratégicos justamente porque não se enquadravam nos seus pilares essenciais (bipolaridade e armas nucleares). Assim, as tensões no chamado "Terceiro Mundo" não ocupavam lugar relevante no campo de estudos. 
Por fim, tem-se que o impacto dos debates acadêmicos e da institucionalização do campo pouco contribuíram nesta primeira fase, por conta da dinâmica evolutiva do campo, que teve um nascimento lento, seguido de uma frenética expansão e nivelamento, tendo o seu pico na chamada “era de ouro" (1955-1965), já comentada por Walt (1991).

Paralelamente ao desenvolvimento e consolidação dos Estudos Estratégicos como a principal escola de pensamento em matéria de segurança internacional, outras duas abordagens também seguiram seus respectivos cursos, em regra conflitando mas, por vezes, até dialogando com os Estudos Estratégicos. Porém, não chegaram a representar um desafio à hegemonia deste. Um dos campos viria a ser conhecido como Estudos para a Paz (Peace Research no início; Peace Studies mais tarde) e, o outro, como Controle de Armas (Arms Control).

Ainda que estes três campos tenham mais similaridades que diferenças, como argumentam Buzan e Hansen (2010: 153), à época os Estudos para a Paz faziam forte oposição aos Estudos Estratégicos, enquanto que o Controle de Armas situava-se a meia distância de ambos, dado que parte de seus pesquisadores operavam de dentro da estrutura teórica dos Estudos Estratégicos, e parte operava de modo um pouco mais independente, constituindo o grupo em torno dos Estudos para a Paz. Entretanto, todos os grupos buscavam respostas para um mesmo problema: como obter segurança em um contexto internacional marcado pela confrontação bipolar entre as duas únicas superpotências nuclearmente armadas?

No caso dos Estudos para a Paz, tem-se que seu surgimento data dos anos 1950, sendo uma espécie de dissidência bastante crítica dos Estudos Estratégicos. Fundados em uma visão mais político-normativa da teoria da dissuasão nuclear, o campo se propunha a questionar as bases morais e racionais dos Estudos Estratégicos, além de buscar resignificar os conceitos de guerra e paz. Particularmente forte na Europa e Japão, conseguiram se tornar a corrente dominante apenas em parte da Escandinávia e da Alemanha. Importante contribuição dos Estudos para o campo da segurança foi a redefinição do conceito de paz, e sua divisão em duas vertentes, as chamadas paz positiva e a paz negativa. A paz positiva seria identificada de várias formas, partindo basicamente das ideias de integração, formação de comunidades de segurança, criação de normas e regimes e chegando até a discussão acerca da desigualdade e injustiça social enquanto que a paz negativa seria identificada com a ausência de guerra e de violência física em larga escala, abrindo espaço para mais pesquisas focadas na dimensão militar da segurança (BUZAN; HANSEN, 2010: 102).

Já no caso do Controle de Armas, a grande preocupação dos seus pesquisadores estava no risco coletivo à sobrevivência, por conta da intersecção da rivalidade bipolar com a rápida 
evolução da tecnologia das armas nucleares. Posto de outra forma, pode-se dizer que a rivalidade bipolar-nuclear criava um interesse comum nas superpotências acerca da sobrevivência. Portanto, em última análise seu foco estava na redução das tensões e na tentativa de se construir confiança nas relações entre Washington e Moscou. Campo bastante técnico e complexo, parte produto da "era de ouro" do pensamento estratégico, parte uma clara reação a ele, o Controle de Armas ganhou forma de conceito estratégico nos idos dos anos 1950, mas sua obra fundadora, The Control of the Arms Race, de Hedley Bull, foi editada apenas em 1961 (BUZAN; HANSEN, 2010: 112), dando origem a uma profícua produção intelectual ao longo das futuras décadas.

Com relação às forças motrizes, pode-se afirmar que a nem a política das grandes potências, nem a tecnologia impactaram de modo decisivo na evolução do campo durante o desenrolar da Guerra Fria, dados que os fatos da rivalidade bipolar e das armas nucleares estavam dados desde o início da confrontação. O que mais impactou a evolução do campo, nesta fase, foi uma somatória dos eventos com os debates acadêmicos. No caso dos eventos, a formação da Comunidade Econômica Europeia e da OTAN (contrapondo-se ao Pacto de Varsóvia) foram cruciais, juntamente com uma extensão do olhar do Norte (leia-se EUA e Europa Ocidental) para o Sul, envolvendo-se diretamente nos processos de descolonização, em conflitos armados e em questões econômicas por todo o chamado Terceiro Mundo. Esse alargamento do espectro, somado ao alto nível dos debates acadêmicos entre as três correntes, o qual alargou e fortaleceu a base teórica do campo dos estudos de segurança como um todo, conduziu e deu o norte da evolução da disciplina por toda a Guerra Fria.

Contudo, o final inesperado e um tanto abrupto da Guerra Fria, com a subsequente - e até então impensável - dissolução da União Soviética, abalou todas as estruturas do campo dos estudos de segurança internacional, obrigando seus pesquisadores, em um primeiro momento, a repensarem a validade e os limites de seus modelos, conceitos e teorias. É certo que, antes desse evento-chave, já vinham se desenvolvendo novas abordagens, notadamente a partir dos anos 1970, com a introdução de temas tais como segurança econômica e segurança ambiental. Contudo, visões mais abrangentes e aprofundadas do tema da segurança, para além da sua dimensão político-militar e estatocêntrica, só tiveram possibilidade real de desenvolvimento após o colapso da ordem bipolar.

Colocado dessa maneira, no pós-Guerra Fria ficou bastante claro desde o início que o campo de estudos, como um todo, começava a se segmentar em duas alas (ou perspectivas) fundamentais, a saber: uma primeira ala, tributária da tradição epistemológica herdada da Guerra Fria, seria denominada de "tradicionalista", sendo que a outra, dedicada a expandir os 
limites teóricos da disciplina, seria denominada de "abrangente e aprofundada" (wideners and deepeners $)^{4}$. Alguns destes últimos de fato surgiriam a partir do fim da Guerra Fria, mas outros eram herdeiros dos Estudos para a Paz, na sua vertente de "paz positiva”, do Pósestruturalismo e do Feminismo.

A ala "tradicionalista" seria formada por uma amálgama entre as três perspectivas que orientaram os estudos durante toda a Guerra Fria. Dado possuírem, a essa altura dos acontecimentos, muito mais semelhanças que disparidades (como já notado acima por Buzan e Hansen), elas acabaram por se agrupar e somar forças, ainda que mantendo cada uma suas características próprias, uma vez que a crise institucional (que chegou a ser pensada como terminal, a certa altura) no campo de estudos de segurança internacional parecia mesmo inevitável. Porém, não foi isso o que ocorreu. Ao contrário, em que pese a marginalização da dimensão político-militar dos estudos de segurança e a concorrência posta pelo renovado interesse acadêmico acerca das novas dimensões da segurança, ao sobreviver ao fim da Guerra Fria e ao desaparecimento da União Soviética, o campo demonstrou vigor e resiliência notáveis.

Uma das explicações para isso está no fato de que a contínua institucionalização do campo ao longo das décadas, com a formação de inúmeros centros de pesquisa, cursos universitários e uma ampla rede de publicações manteve a comunidade acadêmica agregada e disposta a pensar em como dar sobrevida ao campo, "apesar do desmantelamento pacífico e voluntário da ordem bipolar" (BUZAN; HANSEN, 2010: 159). Outra explicação reside na mudança estratégica de foco: sai de cena o confronto bipolar-nuclear e entra a questão da proliferação nuclear. A contínua evolução tecnológica não apenas colocou essa problemática, como também manteve vivo o debate acerca dos armamentos, da corrida armamentista, dos mísseis balísticos (e seu controle), das armas de destruição em massa, etc. Tempos depois, a isso se somaria o problema do terrorismo, e a equação "armas de destruição em massa mais terrorismo" agitaria o campo até os dias atuais. Por último, no lugar do conflito bipolar entraram os conflitos regionais e sub-regionais, além de toda uma discussão sobre a questão da polaridade no pós-Guerra Fria, com destaque para a ascensão da China, questões estas bastante prementes.

Viva e renovada, a ala tradicionalista segue seu curso, com uma agenda bastante ampla e complexa, ainda que não detenha mais a hegemonia do campo de estudos. Nos pós-Guerra

\footnotetext{
${ }^{4}$ Doravante, esta ala será simplesmente denominada de "nova agenda".
} 
Fria, ela precisou se recolocar no cenário acadêmico-institucional, dividindo espaço e recursos com as novas perspectivas, além de se dispor a travar um saudável debate com estas.

Com relação à ala "nova agenda", esta começou a se estruturar ainda nos anos 1980, antes do evento-chave que foi o final da Guerra Fria. Seguindo os passos de algumas inovações introduzidas nos anos 1970 e já comentadas (segurança econômica e ambiental), este conjunto de novas perspectivas somente obteve espaço político e visibilidade a partir do colapso da ordem bipolar. Na verdade, elas constituem um conjunto de diferentes abordagens, com diversos objetos referentes e setores aptos à aplicação do conceito de segurança, o qual, doravante, seria objeto de discussão aberta, notadamente na Europa. Em suma, todas buscavam se contrapor ao modelo realista dominante, representado pela ala tradicionalista, no qual a única dimensão é a político-militar e o objeto referente é apenas o Estado. Interessante notar, também, uma clara distinção metodológica entre a academia baseada nos EUA e a baseada na Europa no que tange a "nova agenda". Nos EUA, o Construtivismo adentra ao campo, nos anos 1990, a partir de um debate interno às Relações Internacionais entre os racionalistas e os reflexivistas enquanto que, na Europa, a origem das novas abordagens está ancorada na tradição dos Estudos para a Paz, que foram estranhamente rebatizados apenas como "Estudos de Segurança", e é nesse continente que se inicia um debate explícito acerca da definição de segurança, da busca por um conceito definitivo e abrangente, coisa que não ocorreu nos Estados Unidos.

Ainda de acordo com Buzan e Hansen (2010), pode-se distinguir como as principais novas escolas de pensamento em matéria de segurança: i) o Construtivismo, mais conservador no que tange a ampliação da agenda e do conceito de segurança; ii) o Pós-Colonialismo, a Segurança Humana, os Critical Studies e o Feminismo, todos engajados na forte ampliação da agenda e do conceito, cada qual a seu modo; e iii) o Pós-Estruturalismo e a Escola de Copenhague, enquanto abordagens discursivas e também firmes defensoras da ampliação.

Sinteticamente, pode-se afirmar que o Construtivismo, com seu foco no papel e no jogo das normas, das identidades e na força das narrativas, comporta duas vertentes: a convencional e a crítica. Assim posto, tem-se que a sua vertente convencional é a que menos antagoniza com a ala tradicionalista, uma vez que adota, como ponto de partida, uma definição bastante estreita e conservadora de segurança, e opera com os mesmos pressupostos dos tradicionalistas, a saber: o objeto referente segue sendo o Estado e a dimensão da segurança permanece político-militar. Contudo, o Construtivismo convencional, ao invés de fazer a leitura da realidade pelas lentes dos tradicionalistas (Realismo), o faz por lentes de caráter ideacional, enfatizando normas, identidades e narrativas. Para os autores citados, a 
obra fundadora do campo ${ }^{5}$ é The Culture of National Security (1996), editada por Peter J. Katzenstein (BUZAN; HANSEN, 2010: 192).

Já no caso do Construtivismo crítico, o foco está quase que totalmente na análise do discurso, e em como este constrói a história, as identidades e, em suma, as políticas de segurança. Dentro desse sub-campo, há uma corrente que está mais preocupada em trabalhar com teoria social e sociologia da história, e outra mais identificada com as relações entre as identidades e a segurança. É fato que não se pode traçar com clareza a linha que separa o convencional do crítico, por conta das várias sobreposições mas, ainda assim, as duas correntes seguem marcando posições relativamente distintas.

O Pós-Colonialismo engloba uma série de diferentes perspectivas e faz algumas sobreposições com o Construtivismo crítico; entretanto, possui algumas características próprias, tais como a necessidade de se repensar a concepção estatocêntrica do sistema quando se trabalha com questões do chamado Terceiro Mundo, dado que esse Estado, objeto de estudo, foi moldado a partir de uma concepção europeia/ocidental, e ainda por cima datada. Modelo inapto, portanto, para a distinta realidade do Terceiro Mundo. Daí a crítica aos conceitos ocidentais de "Estado falido", de desenvolvimento/subdesenvolvimento, e da imposição de uma ordem neoliberal a todo o planeta. Portanto, um novo conceito de segurança e um novo aparato teórico para pensar esta devem ser desenvolvidos em sintonia com a realidade do "Sul", e não com a engessada e reducionista perspectiva do "Norte".

A ideia de Segurança Humana, bem como sua consolidação enquanto escola de pensamento, tem suas origens na tradição pós-colonial. Porém, a inclusão definitiva do conceito de desenvolvimento dentro do conceito de segurança se deu através do PNUD, que institucionalizou via ONU, em 1994, o conceito de segurança humana. Esse conceito deslocou o objeto referente do Estado para as pessoas, para o indivíduo, levantando uma série de novas questões, ameaças e setores nos quais a segurança poderia ser aplicada, formando um grande arco de novas possibilidades. Essa centralidade no bem-estar humano foi revolucionária, de fato, e o campo tem adquirido cada vez mais espaço via institucionalização, discursos e políticas governamentais.

Os chamados Critical Studies, por sua vez, apesar de também elegerem o ser humano como objeto referente, divergem da Segurança Humana no sentido de defenderem a emancipação, conceito importado da Escola de Frankfurt, e a criação de "audiências de

\footnotetext{
${ }^{5}$ No caso, é importante esclarecer que a obra considerada fundante da perspectiva construtivista em si é Social Theory of International Politics, de Alexander Wendt, enquanto que o trabalho de Katzenstein citado traz, pela primeira vez, a perspectiva construtivista aplicada ao tema da segurança.
} 
segurança". Consideram que não se pode confiar no Estado enquanto agente provedor da segurança dos indivíduos. Na verdade, é o Estado que torna os indivíduos inseguros, e a ordem econômica neoliberal abraçada pelos Estados só faz piorar a situação dos indivíduos. Nesse sentido, a segurança só viria através da emancipação progressiva dos indivíduos e da construção de comunidades políticas mais orgânicas que o velho e obsoleto Estado-nação.

No caso do Feminismo, é interessante notar que essa abordagem compartilha muito da experiência dos Critical Studies, ao defender a ideia da emancipação e a extensão do objeto referente para as mulheres, em específico, e para setores não-militares, de um modo mais difuso. Trabalhando com o conceito de "experiência", o campo faz amplo uso da Antropologia e dos Estudos de Gênero, buscando posicionar a mulher como objeto referente a ser protegido não apenas em situações de conflito armado (onde a violência contra as mulheres é particularmente cruel), mas também em situações de ausência deste.

Por fim, como um dos representantes da abordagem discursiva ${ }^{6}$, o Pós-Estruturalismo também adentrou ao campo de estudos, mantendo a abordagem altamente crítica da concepção estatocêntrica e do foco político-militar adotado pela ala tradicionalista. A ausência de uma problematização histórica, normativa e política da realidade pelos tradicionalistas era o que mais eles criticavam. A grande pergunta que se colocaram foi: o Estado precisa mesmo de inimigos? A partir daí, desenvolveram toda a sua linha de pesquisa, enfatizando a importância do "outro" na construção das identidades (individuais e coletivas) e das relações de diferença, as quais podem se degenerar para relações de conflito.

Este sintético exame das distintas abordagens supracitadas deixa bastante claro que a grande força motriz que impulsionou a "nova agenda" foram os debates acadêmicos, seguidos por uma contínua e robusta institucionalização nos dois lados do Atlântico. O vigoroso debate interno acerca da expansão do objeto referente para além do Estado e a necessidade de se incluir novos setores, novas dimensões da segurança para além da tradicional político-militar só pode se dar quando a política das grandes potências, centrada na Guerra Fria e suas consequências, saiu de cena, deixando uma espécie de "vácuo" que pode, enfim, ser ocupado por novas perspectivas, algumas destas remontando aos anos 1970. Os eventos também deram sua contribuição ao impulso da "nova agenda", por conta não apenas do deslocamento dos conflitos para o "Terceiro Mundo", mas pela mudança nas suas premissas: não ocorriam mais no quadro da bipolaridade e por motivação ideológica, mas sim por motivos étnicos, religiosos, etc., o que levantou uma série de novas questões.

\footnotetext{
${ }^{6}$ A Escola de Copenhague será objeto de análise própria no subitem 1.2.
} 
É interessante notar, por fim, que a evolução dos Estudos de Segurança Internacional, dos anos 1940 até a atualidade, se deu em uma contínua sucessão de escolas de pensamento, todas preocupadas em resolver os problemas advindos do mundo real ao mesmo tempo em que buscavam edificar todo um arcabouço teórico apto a lidar com esses problemas. Ora conflitando, ora cooperando, as diferentes escolas tiveram as suas dinâmicas estabelecidas pela conjunção das forças motrizes aqui examinadas, e as perspectivas para a contínua evolução do campo são bastante promissoras. No atual momento histórico, marcado pelos trágicos acontecimentos do Onze de Setembro e pela subsequente "Guerra Global ao Terror", nem os tradicionalistas, nem a nova agenda já dispõem de respostas adequadas ou de novas estruturas teóricas dedicadas a compreender o que de fato está se passando. À princípio, os tradicionalistas apontam para um necessário retorno e atualização do modelo estatocêntrico focado na dimensão político-militar. Já os representantes da nova agenda divergem quanto ao tratamento correto da presente problemática, mas algumas propostas já foram ventiladas. Resta saber quais vingarão.

\subsection{A Escola de Copenhague}

A denominada "Escola de Copenhague" (Copenhagen School of Security Studies) corresponde a um seleto grupo de acadêmicos e pesquisadores que trabalhavam em conjunto no Conflict and Peace Research Institute ${ }^{7}$ (COPRI), fundado em 1985, em Copenhague, e foi responsável por desenvolver uma abordagem inovadora ao problema da segurança, através da edificação de um robusto corpo teórico-metodológico apto a lidar com essa questão. Críticas à parte, ela acabou contribuindo, em síntese, para um alargamento das bases do conceito de segurança, além de desenvolver uma nova estrutura teórica destinada a analisar quando, como e por quem determinada questão se torna "securitizada", ou seja, passa a ser merecedora de medidas políticas excepcionais para que se evite a produção de um grave dano a algum “objeto referente", que é o objeto cuja existência se faz ameaçada pela questão securitizada.

\footnotetext{
${ }^{7}$ O COPRI, que foi fundado e era financiado pelo Parlamento dinamarquês, tornou-se uma instituição subordinada ao Ministério de Pesquisa e Tecnologia da Informação da Dinamarca ainda nos anos 1990, tendo-se fundido, em 1993, ao Danish Institute for International Studies, um instituto de pesquisa independente. Contudo, a maior parte da agenda original do COPRI e que consolidou a Escola de Copenhague tem sua continuidade, atualmente, no CAST (Centre for Advanced Security Theory), um centro de pesquisa dirigido pelo Prof. Ole Waever e subordinado a Universidade de Copenhague. Inaugurado em 2008, ele conta com um orçamento bastante generoso fechado até o final de 2013. Logo, em termos institucionais, a Escola encontra-se apoiada, hoje, no CAST, ainda que outras figuras-chave (Barry Buzan, por exemplo) continuem operando a partir de centros diversos.
} 
Surgida no início dos anos 1980, tem como obra fundadora o livro de Barry Buzan denominado People, States and Fear: The National Security Problem in International Relations, lançado em 1983, o que foi, quase uma década depois, totalmente reformulado, atualizado e relançado sob o título People, States, and Fear - An Agenda for International Security Studies in the Post-Cold War Era, claramente indicando o impacto do final da Guerra Fria nas suas formulações teóricas e na sua proposta de redefinição da agenda de pesquisa neste novo cenário.

Desde o seu início, a Escola já trabalhava com questões tais como a reformulação do conceito de segurança, com a segurança europeia, com as relações entre a segurança regional e a global e, principalmente, com a teoria de segurança regional, esforço este que se consumaria, mais tarde, na Teoria dos Complexos Regionais de Segurança. Contudo, foi a partir da "janela de oportunidade" que se abriu com o final da Guerra Fria que a Escola ganhou visibilidade e, mais madura, passou a produzir o que constitui o núcleo de seu pensamento, o qual gira em torno de três eixos fundamentais: i) a teoria de securitização; ii) o conceito de segurança societal; e iii) a teoria dos Complexos Regionais de Segurança.

\subsubsection{A teoria de securitização}

A teoria de securitização busca explicar as dinâmicas de segurança que se desenvolvem em cada um dos setores existentes identificados pela Escola (militar, político, societal, etc.). Tendo como ponto de partida o denominado "speech act" (ato de discurso), ela operacionaliza uma visão discursiva de segurança, que é a proposta por esta corrente teórica. Ora, desde o trabalho de Wolfers (1953) o conceito de segurança (cuja discussão segue em aberto $^{8}$ e bem comporta um trabalho à parte), além de enfatizar a segurança nacional e a ambiguidade deste "símbolo", comporta dois sentidos, um objetivo e outro subjetivo. Em termos objetivos, segurança implica na ausência de ameaças a valores que são caros ao Estado; em termos subjetivos, na ausência do medo de que estes valores possam vir a ser atacados (WOLFERS, 1953: 485).

Já na sua vertente discursiva, segurança "is the move that take politics beyond the established rules of the game and frames the issue either as a special kind of politics or as

\footnotetext{
${ }^{8}$ Vale destacar que, apesar de toda a discussão, alguns autores entendem que o conceito, em si, não precisa ser revisto, permanecendo válida a formulação inicial de Wolfers. Para Baldwin (1997), por exemplo, o conceito precisa ser melhor explicado, e não reformulado. O que toda a discussão citada objetiva, de fato, é a redefinição das agendas de segurança, e não do conceito. Trabalhar problemas tais como: segurança para quem? Para quais valores? De quais ameaças? A quais custos?; dentre outros, seria muito mais vantajoso para o avanço do campo do que buscar reformular o conceito em si.
} 
above politics. Securitization can thus be seen as a more extreme version of politicization." (BUZAN et al., 1998: 23). Nessa linha, os autores seguem argumentando que

in theory, any public issue can be located on the spectrum ranging from nonpoliticized (meaning the state does not deal with it and it is not in any other way made an issue of public debate and decision) through politicized (meaning the issue is part of public policy, requiring government decision and resource allocations or, more rarely, some other form of communal governance) to securitized (meaning the issue is presented as an existencial threat, requiring emergency measures and justifying actions outside the normal bounds of political procedure) $)^{9}$ (BUZAN et al., 1998: 23-24).

Portanto, é esse movimento do "não-politizado" ao "securitizado" que conforma a dinâmica da securitização, a partir do "ato de discurso" verbalizado por algum ator ou atores securitizantes, os quais via de regra são parte das elites do Estado. Se bem-sucedida a securitização, a questão assim identificada sai da esfera do comum e adentra a esfera do "excepcional", no sentido schmittiano do termo, demandando medidas excepcionais e de urgência para evitar que esta questão provoque algum dano ao objeto referente (estado territorial, economia, identidade coletiva, etc.). Já a desecuritização, evidentemente, seria o processo reverso.

Um último fator relevante está no caráter e comportamento do "público" (audience) receptor do discurso de securitização, que pode variar desde outras elites, passando pelos setores militar, político, podendo até mesmo ser a opinião pública. Quando este "público" se convence da existência de uma ameaça existencial a algum objeto referente, fica aberto o caminho para a imposição de medidas excepcionais, por conta da urgência da ação e do grau do perigo que se avizinha. Ora, segurança, em termos básicos, tem a ver com sobrevivência, e é na busca pela sobrevivência dos objetos referentes que se desenvolvem as práticas de securitização.

\subsubsection{Setores e segurança societal}

Por sua vez, o conceito de segurança societal se inscreve dentro da estrutura multisetorial adotada pela Escola, no que tange às diferentes dimensões da segurança. Nesse sentido, a Escola propõe que se vá além da dimensão político-militar e que sejam incorporadas outras dimensões cuja relevância entendem ser indiscutíveis no contexto atual. Isso posto, a Escola trabalha com cinco dimensões de segurança, as quais denomina de

\footnotetext{
${ }^{9}$ Destaques e grifo nosso.
} 
"setores". De acordo com Barry Buzan, Ole Waever e Jaap de Wilde, na obra que melhor sintetiza o pensamento da Escola (Security - A New Framework for Analysis), publicada em 1998, estes setores são ${ }^{10}$ : o setor militar, o setor ambiental, o setor econômico, o setor político (apartado do militar) e o setor societal, sendo este último a maior contribuição da Escola ao tema.

O setor militar, que desde o início sempre foi o núcleo tradicional dos estudos de segurança, é o mais propenso, dada sua natureza, a tornar altamente institucionalizado o processo de securitização. Tendo como objeto referente o estado territorial, é na proteção deste que está o foco da dinâmica de securitização, cujos agentes securitizadores podem ser, por vezes, de difícil identificação.

Falar em segurança militar implica, por sua vez, na conjunção entre as reais capacidades defensivas e ofensivas do Estado com as percepções das respectivas capacidades e intenções dos outros Estados (BUZAN et al., 1998: 51). E isso se dá nos níveis regional ou sub-regional, uma vez que o cenário do pós-Guerra Fria contempla muito mais possibilidades de conflitos nesses níveis e na "periferia" do sistema do que alguma possibilidade real de conflito global, que era a regra nos tempos da bipolaridade.

O setor ambiental, por seu turno, já era uma área de preocupação acadêmica (como demonstrado anteriormente) nos anos 1970, em plena vigência da rivalidade bipolar-nuclear. Ele foi ganhando visibilidade à medida que o movimento ambientalista foi se estabelecendo como uma poderosa força política, aliando-se a organizações internacionais, governos e academias. Contudo, as propostas de se aplicar a teoria de securitização ao setor ambiental são bastante recentes, e derivam da chamada "agenda política" do setor, a qual faz relativa oposição (apesar das sobreposições de algumas propostas e posições) a "agenda científica". Esta, dominada pela comunidade científica, faz o possível para evitar a securitização do setor, enquanto que na "agenda política" podem se encontrar alguns movimentos no sentido da politização e da securitização do setor. Evidentemente, ambas as agendas são socialmente construídas, e o embate entre os agentes securitizantes e os não-securitizantes tem sido bastante polêmico.

O objeto referente, aqui, comporta algumas diferenças, dadas as disputas acima mencionadas. É claro que, basicamente, o objeto referente é o próprio meio ambiente, mas uma importante derivação concorre com essa ideia, ou seja, para alguns, as ameaças pairam sobre a civilização humana e o nexo natureza-humanidade. Daí resulta que, com a indefinição

\footnotetext{
${ }^{10}$ Barry Buzan já havia iniciado esse estudo setorial em "People, States and Fear", mas a sua forma definitiva só foi apresentada em "Security...", de 1998.
} 
sobre o objeto referente, a lista de possíveis ameaças e vulnerabilidades torna-se bem maior do que poderia ser, reforçando a posição dos favoráveis à securitização. Apesar disso, poucas são as securitizações bem-sucedidas, e notadamente se dão ao nível local.

Já o setor econômico é o mais controverso de todos; afinal, em um sistema capitalista, a insegurança é a regra, e não a exceção. Mais ainda, no modelo atual, de economias de mercado abertas e sob uma ordem internacional capitaneada pela Organização Mundial do Comércio (OMC), cujos postulados fundamentais são o livre comércio e a progressiva e contínua redução das barreiras ao capital, qual é o real sentido de se falar em segurança econômica? Para os autores trabalhados, os movimentos de securitização são, "essencialmente, parte do debate político-ideológico que se desenvolve dentro da Economia Política Internacional", o que implica na adoção de medidas econômicas protecionistas/nacionalistas sob o argumento da "lógica da sobrevivência", mas sem deixar de lado ou abandonar, ao menos no plano do discurso, o comprometimento com a ordem liberal vigente (BUZAN et al., 1998: 115).

No caso do setor político, que a Escola apartou do militar, o foco está na "estabilidade organizacional da ordem social" (BUZAN et al., 1998: 141). Portanto, relaciona-se a ameaças não-militares à soberania. Nesse sentido, $\operatorname{Buzan}^{11}$ (1991: 118-119) afirma que:

Political threats are aimed at the organizational stability of the state. Their purpose may range from pressuring the government on a particular policy, through overthrowing the government, to fomenting secessionism, and disrupting the political fabric $f$ the states $o$ as to weaken it prior to military attack. The idea of the state, particularly its national identity and organizing ideology, and the institutions which express it, are the normal target of political threats. Since the state is an essencially political entity, political threats may be as much feared as military ones. This is particularly so if the target is a weak state. But even when the state is both strong and powerful, political threats might still be a source of concern. France and Italy in the immediate post-war years were strong on national grounds, but significantly divided in terms of organizing ideology. Even the United States feared communist influence in its political life. In both cases, the fear was that successful political interference might win substantial policy rewards in terms of changed foreign alignment.

Fica bastante claro, portanto, que o objeto referente, tal como no caso do setor militar, é o estado territorial, que pode ser ameaçado por movimentos desestabilizadores de caráter ideológico, secessionista, etc., que pretendem derrubar o governo por conta própria ou preparar o terreno para uma derrubada via militar. Os exemplos históricos acima citados por

\footnotetext{
${ }^{11}$ Essa citação foi repetida em Buzan et al., 1998: 142, mas sem a extensão aqui apresentada, que assim o foi por ter melhor poder explicativo.
} 
Buzan dão uma perfeita dimensão do problema e, nesse cenário, um movimento de securitização pode ocorrer, para proteger a integridade e estabilidade da ordem social vigente.

Por fim, o setor societal, uma das grandes contribuições teóricas da Escola, tem no núcleo de seu objeto referente a noção de identidade coletiva. Logo, nos termos de Buzan et al., (1998: 119), uma ameaça à segurança societal surge quando uma determinada comunidade identifica algo como constituindo uma ameaça à sua sobrevivência enquanto comunidade. Essa comunidade não é necessariamente uma nação ou uma sociedade mas, à princípio, apenas uma construção social na qual o elemento identitário, ao mesmo tempo que individualiza seus membros no plano pessoal, os unifica no plano coletivo; das ideias, práticas, cultura, religião e costumes.

Problemas terminológicos à parte, o fato é que a ameaça é sempre uma construção, no plano do discurso, do "outro" como um agente potencial ou efetivamente apto a causar dano ou mesmo a destruir a integridade da comunidade, do chamado "nós". E é a partir da oposição "nós" versus "outro" que se constrói o discurso e as práticas securitizatórias nesse setor.

A segurança societal, portanto, pode ser definida do seguinte modo:

[...] in the contemporary international system, societal security concerns the ability of a society to persist in its essencial character under changing conditions and possible or actual threats. More especifically, it is about the sustainability, whitin acceptable conditions for evolution, of traditional patterns of language, culture, association, and religious and national identity and custom. (WAEVER et al., 1993: 23).

Essa ideia de segurança, associada à lógica de ameaças e vulnerabilidades que perpassa, com suas especificidades, todos os setores examinados, pode produzir dinâmicas regionais bastante distintas. Se, no plano global da segurança, o maior exemplo de ameaça societal foi descrito por Huntington (1997) nos termos de um "choque de civilizações", no plano regional tem-se, por exemplo, o caso europeu (cenário original de toda a teoria), onde o contraponto à "europeização" globalista promovida pela União Europeia tem sido o renascimento do nacionalismo, derivando tanto para uma "onda de securitização" quanto para, no extremo, discursos políticos xenófobos e um preocupante crescimento dos partidos de extrema-direita.

Falar em segurança societal significa, portanto, falar em proteger identidades socialmente construídas contra a ação do "outro", do "invasor", daquele que carrega um potencial de destruição progressiva dos padrões de linguagem, cultura, religião, identidade nacional, etc. No plano analítico, essa ideia é bastante efetiva, segundo Paul Roe (2010: 216) 
para a devida compreensão, por exemplo, dos problemas de segurança em Estados multiétnicos; nas relações entre governos nacionais e minorias étnicas; e nos padrões de conflitos em Estados considerados "fracos”. Não obstante, ela é uma boa ferramenta para se analisar problemas de segurança suscitados por questões migratórias tanto intra como entre Estados, além das dinâmicas regionais de conflitos, para as quais diversos setores costumam concorrer.

É importante ter em mente que os setores não são unidades isoladas; vale dizer, eles interferem e interagem uns com os outros, gerando problemáticas distintas. No caso do setor societal, Waever et al. (1993: 46-58) elaboraram uma análise bastante profícua acerca das interações deste setor com os demais. Observe-se o setor militar, por exemplo. Em regra, se um Estado está sofrendo uma ameaça militar externa, sua sociedade também está sob ameaça, a não ser que: i) tal ameaça tenha como objetivo libertar alguma minoria oprimida por este Estado; ii) derrubar um governo tirânico, cujas ações atentam contra sua própria sociedade, ou ainda; iii) libertar uma sociedade da ocupação imperial externa, como ocorreu na $2^{\text {a }}$ Grande Guerra. Exceções à parte, o padrão é o Estado fornecer proteção militar à sua sociedade, contra possíveis agressões externas. O problema se coloca quando o setor militar assume um protagonismo político de tal relevo que ele não apenas assume o controle do Estado como passa a perseguir determinados grupos - podendo gerar conflitos étnicos e massacres - e a oprimir a sociedade como um todo, seja em seu proveito ou em nome de um partido ou força política dominante.

No caso do setor político, é interessante destacar que, em tese, deveria haver uma clara complementariedade entre o governo e a sociedade, dado que é função do primeiro garantir a segurança do Estado contra ameaças à ordem estabelecida e proteger a sociedade via o estabelecimento de uma ordem jurídica legitimamente instituída. Entretanto, na prática, muitas vezes os governos não representam de fato a sociedade ou, pior, constituem uma ameaça à sua existência. Se segurança societal implica na habilidade de determinada sociedade em manter suas características essenciais (língua, cultura, identidade nacional, etc.) frente a ameaças à sua sobrevivência e a uma realidade em constante transformação, então é muito mais provável, para os autores (1993: 49) que tais ameaças provenham do aparato governamental do Estado do que propriamente de Estados ou governos estrangeiros. De fato, na trajetória da formação dos Estados nacionais, foi frequente a busca, pelos governos, de uma ampla homogeneização da sociedade, quando não a simples supressão das identidades societais sub-nacionais, com o intuito de forjar uma única identidade nacional, consolidando o nascente Estado-nação e eliminando, de pronto, eventuais adversidades que poderiam emergir, com o tempo, derivadas de tensões e conflitos entre as variadas etnias e grupos societais 
doravante reunidos sob um único governo, em um único Estado. Evidentemente, tal processo nem sempre foi bem sucedido, e sequer se deu de forma pacífica e linear, sendo inúmeros os exemplos de violência, massacres, guerras civis e toda a sorte de hostilidades que acompanharam a formação histórica do Estado-nação.

Por sua vez, a relação entre os setores societal e econômico é deveras complexa, e dificilmente seria possível, aqui, fazer uma avaliação adequada, ainda que extremamente breve, dessa temática. O que se poderia destacar é que, como já dito anteriormente, nos marcos do capitalismo, a insegurança é a regra, e não a exceção. Assim, as sociedades capitalistas vivem, em termos econômicos, sob níveis contínuos de insegurança, maiores ou menores, os quais são uma caraterística inerente ao sistema; faz parte da sua dinâmica. Daí a necessidade de uma constante adaptação, por parte das sociedades, às inovações, mudanças de escala, novas tecnologias, concorrência, etc., que são a marca de um mercado global em contínua transformação. E tal esforço de adaptação acaba favorecendo os efeitos "cosmopolitas", homogeneizantes, do capital, pondo em risco qualquer concepção de identidade ou cultura de viés mais estático ou tradicionalista.

A partir desse quadro, pode-se elencar as ameaças em três categorias: i) as derivadas da eficiência do sistema capitalista; ii) as derivadas de suas ineficiências (que não são poucas, diga-se de passagem), e iii) as derivadas de sua estrutura global (Waever et al., 1993: 52). Como exemplo da primeira categoria tem-se, como já disposto acima, um perene conflito entre o que se poderia chamar de "tradições", cuja base é local ou regional, e a força padronizadora, homogeneizante, do capital, com seus produtos, modas, apelos globais que, de certa forma, podem ser vistos como instrumentos de uma contínua "ocidentalização" do planeta, da transformação do american way of life em uma espécie de global way of life, o que causa, por vezes, choques e conflitos em sociedades que têm um conceito de cultura nacional muito bem estruturado e arraigado no imaginário coletivo da população. Assim, a defesa do patrimônio cultural nacional, das tradições, costumes, língua, etc., contra a "ameaça estrangeira" (entenda-se "ameaça ocidental" ou "ameaça norte-americana") está na base, por exemplo, dos movimentos de caráter anti-globalização.

No caso da segunda categoria, os exemplos são as crises econômicas, recessões, depressões, queda do padrão e da qualidade de vida, dentre outros fenômenos. Nesses casos, quando a crise se agudiza, não é incomum que os estrangeiros - notadamente os trabalhadores estrangeiros (na Europa isso já é clássico, infelizmente) - sejam apontados como "bode expiatório“. Logo, eles não apenas "tiram o emprego" dos trabalhadores nacionais como absorvem "indevidamente" as parcas medidas sociais que o Estado tenta colocar em prática. 
Nesse contexto, as crises sociais e a polarização extremada podem gerar graves consequências humanas. Para os autores (1993: 54) o que esses momentos geram de importante, além de uma grave desarmonia social, são as pressões por protecionismo, uma política externa mais agressiva e uma maior distribuição das riquezas, apesar do estado precário das contas nacionais. Na ausência de respostas a tais demandas, a desestabilização do governo é inevitável.

Por último, em termos estruturais, os autores se valem do modelo explicativo de centro-periferia para avaliar as tensões e contradições inerentes ao capitalismo. Sem estender muito a discussão, o ponto aqui é que a periferia, dadas suas condições materiais e estruturais, vive constantemente exposta ao que chamam de "qualidades mais destrutivas" do capitalismo, o que leva os países aí classificados a constantes crises, de toda a sorte, ficando sujeitos a "saltos e sobressaltos", sem um padrão contínuo de estabilidade e crescimento. Nessas condições, mantes a coesão societal chega a ser, em certos casos, uma arte. Muito corretamente os autores afirmam que "o sistema capitalista, no seu todo, é uma ameaça à segurança societal“" (1993: 55). Ora, a insegurança é a marca do sistema; daí ser tão difícil falar em segurança econômica.

Cabe, agora, analisar a relação entre os setores ambiental e societal. Ameaças a segurança societal derivadas do setor ambiental surgem quando a identidade coletiva de uma determinada população possui fortes vínculos com o ambiente que habitam. Quanto mais adaptada uma cultura a determinado ambiente natural, mais fortes são os seus vínculos com este e mais formatada pelo ambiente é a sua identidade (Waever et al., 1993: 55-56). É o caso dos povos que habitam o Ártico, por exemplo, ou ainda dos que habitam as florestas tropicais. Fica claro que, quanto mais ameaçado o ambiente em que vivem, mais ameaçadas estão as suas identidades e, no limite, suas existências enquanto um grupo coeso e determinado. Ao longo dos tempos, muitas sociedades simplesmente desapareceram justamente porque foram privadas do seu ambiente natural, e o risco de extinção, no caso dos exemplos citados, é bastante alto.

Finalizando, é patente a complexidade que envolve a discussão das interfaces entre o setor societal e os demais setores, e é patente também a importância do setor societal para a segurança do Estado. Toda essa teia de inter-relações forma uma agenda de pesquisa muito rica e variada. Por isso mesmo, a intenção aqui foi de apenas destacar alguns aspectos que são mais relevantes para o devido tratamento do problema de pesquisa.

\subsubsection{Complexos regionais de segurança}


Importante ressaltar, também, a contribuição da Escola para o estudo da segurança regional, através do desenvolvimento da Teoria dos Complexos Regionais de Segurança. Trabalhada em detalhes na obra "Regions and Powers - The Structure of International Security”, um trabalho conjunto de Barry Buzan e Ole Waever (2003), essa teoria funda-se em um reexame, à luz do panorama atual, do problema da polaridade do sistema internacional nos pós-Guerra Fria e, definida essa questão, parte para a discussão sobre a proeminência da abordagem regionalista acerca das práticas e discussões sobre segurança.

O argumento básico é que, desde a descolonização, a questão da segurança regional tornou-se mais autônima e proeminente, sendo que o final da Guerra Fria acelerou esse processo. Ora, não existindo mais a rivalidade bipolar, os poderes regionais ganharam mais autonomia e margem de manobra face aos poderes globais. Sustenta, também, que a atual configuração do sistema internacional, que serve de molde para a configuração da estrutura de segurança internacional, possui a forma " $1+4+$ regiões", o que significa que existe uma superpotência - os Estados Unidos -, quatro grandes potências - China, União Europeia, Japão e Rússia -, e as "regiões", cada qual com sua dinâmica própria, definida a partir dos padrões e práticas de segurança que lhes são peculiares. A rigor, duas condicionantes dirigem essa dinâmica interna, a saber, os padrões regionais de poder e os padrões de amizade/inimizade que aí se desenvolvem (BUZAN; WAEVER: 2003).

Essa perspectiva regionalista, como não poderia deixar de fazê-lo, resgata a Geografia e a reconduz ao centro do debate nas Relações Internacionais, uma vez que o mainstream desta perdeu o contato com a disciplina, por conta de sua busca por teorias mais abstratas e por receio das tradicionais reações negativas contra as chamadas "conotações reacionárias da Geopolítica". De certo modo, sustentam os autores, a abordagem do problema da segurança que desenvolvem nessa obra tem muito em comum com a da Geografia Política, ou seja, "a teoria dos complexos regionais de segurança é uma teoria de segurança na qual as variáveis geográficas são centrais" (BUZAN; WAEVER, 2003: 69-70).

Operando em níveis distintos (global, regional e local/nacional), os quais devem ser compreendidos primeiro isoladamente, depois em suas interações, essa teoria tem como conceito-chave a ideia de "complexos de segurança", já formulada em obra anterior ${ }^{12}$ mas que só agora foi possível integrá-la em uma estrutura teórica que permita a sua aplicação em análises empíricas (os chamados "estudos de área“), dado que a função primeira da teoria dos

${ }^{12}$ Cf. Buzan et al., 1998: 201. 
complexos regionais de segurança é a de servir de estrutura para a realização de estudos empíricos acerca de questões de segurança regional.

Concluindo, Buzan e Waever (2003: 84) sustentam que esta teoria tem duas capacidades básicas: i) ela permite que se preveja quando um complexo regional de segurança pode ou não emergir; e ii) ela permite também que se construa um conjunto restrito de cenários dentro dos parâmetros da previsão anteriormente feita. Evidentemente, existem outras possibilidades para a aplicação da teoria, seja para comparar diferentes padrões de segurança em diferentes regiões do globo, seja para auxiliar a elaboração de políticas regionais de segurança, etc. Contudo, não se pode perder de vista que, em todos esses processos, as dinâmicas de securitização/desecuritização ocupam papel fundamental, constituindo o eixo básico dos padrões analíticos.

\subsubsection{O complexo regional de segurança da América do Norte}

Ao contrário do que se poderia inicialmente imaginar - dada a presença hegemônica de uma superpotência global - as Américas não constituem um único complexo regional de segurança, mas sim dois, a saber: o complexo regional de segurança da América do Norte e o complexo regional de segurança da América do Sul, cada qual com suas características e dinâmicas próprias. E o complexo da América do Sul ainda se subdivide em duas áreas distintas, que são o subcomplexo Andino e o subcomplexo do Cone Sul, sendo que cada subcomplexo, igualmente, possui dinâmicas e características distintas.

No caso do complexo regional de segurança da América do Norte (doravante simplesmente "complexo"), é interessante ressaltar que ele engloba não apenas a América do Norte, mas se estende até a Bacia do Caribe e a América Central, tendo como centro de gravidade, por questões óbvias, os Estados Unidos. Daí a razão de, muitas vezes, esse complexo ser ignorado (ou posto em segundo plano), uma vez que sua dinâmica de segurança frequentemente acaba se confundindo com a dinâmica de segurança e os interesses nessa seara dos próprios EUA.

Vale destacar, aqui - considerando os objetivos deste estudo - a formação histórica do padrão básico das relações Estados Unidos-México. Parafraseando Raymond Aron, Buzan e Waever (2003: 274) afirmam que tais relações acabaram por se desenvolver "à sombra da guerra“ (1846-1848), guerra ${ }^{13}$ esta que foi um enorme desastre nacional para o México e que

\footnotetext{
${ }^{13}$ A Guerra EUA-México, além das grandes perdas humanas e materiais, implicou na perda, por parte do México, de mais da metade de seu território para os Estados Unidos.
} 
acabou por delimitar os contornos da fronteira interestatal, contornos estes que poucas modificações sofreram posteriormente. Estabelecida a paz, do final do século XIX até o irromper da Revolução Mexicana ${ }^{14}$ (1910-20) as relações EUA-México gozaram de uma certa calmaria, sendo pautadas por um regime mais liberal com relação aos investimentos norteamericanos no México, os quais foram paulatinamente influenciando não só a economia mexicana mas toda a sua estrutura social e política.

Da Revolução até 1982 (ano da crise da dívida ${ }^{15}$ ) o que se viu, no México, foi a preponderância de um forte viés nacionalista e de um contínuo monitoramento da influência dos Estados Unidos em seu território (BUZAN; WAEVER, 2003: 274). Contudo, não se pode perder de vista a assimetria e dependência crescentes que foram se cristalizando nas relações bilaterais, dados que ainda nos idos de 1898 os EUA já marcavam a sua posição no cenário mundial como uma grande potência, logo após vencerem a Guerra Hispano-Americana neste mesmo ano (BUZAN; WAEVER, 2003: 282). No plano da segurança hemisférica, até a década de 1980 o México era tratado tal como os países da América Central, e as preocupações dos Estados Unidos se dividiam em três frentes: 1) capacidade e vontade política destes países em proteger seus direitos de propriedade e interesses econômicos, evitando, assim expropriações, nacionalizações, não-pagamento de dívidas externas, etc.; 2) "externalidades transfronteiriças" tais como banditismo, imigrações, tráfico de drogas, entre outros $^{16}$, e; 3) estabilidade política dos regimes, o que implicaria em maior ou menor confiabilidade do Estado em questão. Por fim, do ponto de vista militar, a possibilidade de uma intervenção armada no México foi se tornando cada vez mais remota, ao passo que foi recurso corrente com relação aos países centro-americanos.

No período pós-Guerra Fria, para os autores supracitados (2003: 291-292) o México passou a lidar com dois problemas "e meio" de segurança. Um deles foi o levante em Chiapas que, muito simbolicamente, teve início no mesmo dia em que o NAFTA entrou em vigor (01/01/1994). O outro diz respeito à insistência norte-americana no unilateralismo enquanto

\footnotetext{
${ }^{14}$ Os autores consideram que a Revolução começou em 1911, e que o ano de 1917 marcou o seu fim; contudo, existe uma grande divergência com relação a isso, que não cabe aqui discutir. O fato é que em 1917 foi promulgada uma nova Constituição, mas as hostilidades não cessaram de todo. Na historiografia tradicional, considera-se o ano de 1920 como sendo o marco "oficial" do fim das hostilidades armadas.

${ }^{15}$ Segundo Weintraub (2010: 28-30), a crise da dívida de 1982 acarretou, dentre outras consequências, na abertura forçada da economia mexicana e na adoção de um amplo programa de liberalização, alterando, assim, o modelo econômico vigente havia décadas no país.

${ }^{16}$ Tais questões, apesar de serem típicas da região da fronteira e, por decorrência lógica, sujeitas a políticas e ações bilaterais, sempre foram tratadas de maneira unilateral pelos Estados Unidos, tendo a História registrado raros momentos de efetiva participação mexicana no planejamento e execução de tais políticas em conjunto com os EUA.
} 
postura política no trato de questões transnacionais como tráfico de drogas e migrações ${ }^{17}$. O "meio problema“, por fim, diz respeito à questão das drogas, que é percebida pelo México como um problema genuíno de segurança, e não simplesmente porque tal questão foi securitizada pelos Estados Unidos.

O fato é que, após o NAFTA, houve um descolamento do México do bloco centroamericano, e ele passou a ser encarado, pelos EUA, de um modo distinto, tanto nas questões políticas e econômicas quanto das questões específicas da agenda de segurança. Em síntese: ele se tornou um importante parceiro econômico-comercial; portanto, sua estabilidade e segurança impactam diretamente nos interesses e na segurança dos EUA e, por conseguinte, na segurança de todo o complexo.

Para além das questões bilaterais e regionais, é notório que o final da Guerra Fria catapultou os Estados Unidos à posição de única superpotência em um sistema internacional momentaneamente unipolar, e isso alterou a dinâmica de sua política de segurança em todos os níveis (local, regional e global). Caiu a agenda clássica da Guerra Fria, dado o desaparecimento da União Soviética, e entrou em cena um período de reavaliação das ameaças e remodelamento de suas forças. Com isso, securitizou-se ou foram intensificados os processos de securitização face a novas ameaças e vulnerabilidades, considerando-se os novos objetos referentes. Curiosamente, a questão societal é a primeira levantada por Buzan e Weaver (2003: 294-295), que argumentam no sentido de que, embora determinados grupos sociais historicamente tenham securitizado determinadas questões ${ }^{18}$ e agido por conta própria, alegando ausência de proteção estatal (notadamente nos séculos XVIII e XIX), a partir do século XX os Estados Unidos passaram a concentrar sua agenda de segurança nas ameaças externas de caráter político-militar, apenas ocasionalmente securitizando questões internas, tais como as ligadas às divisões culturais, raciais, étnicas e identitárias. As disputas geradas em torno das discussões acerca da manutenção ou fragmentação da identidade de base étnico-

\footnotetext{
${ }^{17}$ Interessante notar que os autores, ao tangenciarem o tema da fronteira, entendem que a construção da infame Cerca (que eles denominam de "algo parecido com um novo Muro de Berlim") não constitui um tema relevante de análise, e subestimam a militarização da fronteira - magistralmente examinada por Timothy Dunn (1997) e que será objeto de estudo mais adiante - afirmando que a militarização é apenas "alegada", colocando-se, assim, na contramão dos fatos.

${ }^{18}$ Os autores não dão um único exemplo, mas esse é o caso típico da securitização do "outro" - chineses, mexicanos, latinos de um modo em geral, etc. -, cuja presença em solo americano representaria, sob determinadas condições e em determinados períodos históricos, uma ameaça aos valores, ao modo de vida e a identidade da "nação norte-americana", que é pensada sob uma perspectiva essencialista, ou seja, a identidade é um simples fato objetivo, que deriva de uma herança étnica, histórica e cultural comum. Monolítica, ela é imune a efeitos evolutivos, derivados das trocas culturais, dos contatos e do hibridismo cultural. A sua fixidez acaba, por conseguinte, criando uma "mítica da pureza“, cujos esforços por sua preservação podem acarretar em graves consequências.
} 
racial da sociedade norte-americana, opondo defensores do multiculturalismo à partidários da preservação de uma identidade considerada "verdadeira", que é a da elite branca, protestante e de origem anglo-saxônica (WASP), por vezes acabaram gerando tensões e conflitos ao longo do tempo, além de episódios de securitização e contra-securitização. No caso, os autores apontam, de um lado, pequenos grupos ativistas cujo objeto referente são largas coletividades de origem hispânica e afro-americana, cuja securitização do tema acionou (e ainda tem potencial para mais) uma contra-securitização por partes de grupos radicais que alegam estar buscando proteger a maioria da população. O atentado em Oklahoma (1995) e o crescimento das milícias nos anos 1990 demonstram a tentativa de defesa "de uma América verdadeira e branca“ contra um Estado visto por demais liberal e as minorias que paulatinamente vão ganhando mais poder e representatividade. Curiosamente, os autores nada falam sobre a peculiar situação da fronteira Estados Unidos-México e seu longo histórico de tensões, violência e segregação. Neste caso, não cabe falar em contra-securitização, mas sim - como pretende-se demonstrar ao longo deste estudo - em securitização pura e simples, que se desenvolveu e fortaleceu via ação de uma série de atores securitizantes cujo alegado objetivo é a proteção da "identidade norte-americana", entendida sob um viés puramente essencialista.

Contudo, no que importa à política de segurança dos EUA, a questão societal é meramente secundária, quando muito - ao contrário do que ocorre na Europa. Daí ser curioso o espaço que os autores deram ao tema. As evidências, tal qual pretende-se demonstrar oportunamente, sugerem que esta questão é extremamente importante no nível regional, ou seja, ao longo da faixa de fronteira e envolvendo praticamente apenas os estados fronteiriços. Não é um problema relevante para o norte do país, por exemplo, e muito menos para os EUA como um todo, apesar do esforço que alguns teóricos, políticos e determinados grupos de interesse dispendem e dispenderam para tentar provar o contrário.

Por derradeiro, Buzan e Waever (2003: 295-298) apontam que, com o alargamento do conceito de segurança em meados dos anos 1990, somado ao fim da Guerra Fria, a agenda de segurança dos EUA foi reformulada, passando a abranger novos temas, tais como o da segurança ambiental, epidemias/infecções em escala global e o crime organizado transnacional, com destaque para sua interface com a questão das drogas (securitizada desde 1974 pelo Presidente Ford). Contudo, no topo da agenda seguem as questões de ordem geoeconômica (primeiro foi o Japão, hoje é a China), de não-proliferação, das armas de destruição em massa, dos "rogue states" (que substituíram os "reds", numa alusão aos países comunistas) e, como novidade, a ascensão do terrorismo como a grande ameaça, substituindo 
o papel que era representado pela União Soviética. Em suma, as questões político-militares continuam dominando a agenda, mas esta agora também abarca outros tipos de ameaças.

\subsubsection{Crítica e debate}

Por mais bem-sucedida que tenha sido a contribuição da Escola de Copenhague ao domínio dos Estudos de Segurança Internacional, esta não poderia passar imune às críticas que, aliás, a ajudaram a refinar suas proposições, além de ter gerado um interessante debate que segue em desenvolvimento.

Um dos maiores críticos da Escola - e que cunhou o termo "Escola de Copenhague" é Bill McSweeney, pesquisador sênior da Universidade de Dublin. Sua grande crítica reside na adoção, pela Escola, de um conceito fixo de identidade, ao invés de um socialmente construído. Ora, esta é a famosa querela entre o essencialismo e o não-essencialismo (ou construtivismo $)^{19}$. Se, de acordo com o essencialismo, as identidades são fixas, tendendo à imutabilidade, de acordo com o construtivismo elas são dinâmicas, sendo historicamente construídas e constituídas pelas relações de poder em uma dada sociedade. Ao discutir as afirmações de Weaver et al. de que: i) "societies are fundamentally about identity " (1993: 05); e ii) "societal security concerns the ability of a society to persist in its essencial character" under changing conditions..." (1993: 05), McSweeney (1996: 83) afirma que tanto "sociedade" quanto "identidade" são tomados pelos autores como realidades objetivas, dadas, prontas para serem descobertas e analisadas. Assim procedendo, eles assumiram o conceito de sociedade, em seu trabalho, como "uma variável independente, um fato social imune a questionamentos, cujos valores e vulnerabilidades são tão objetivos quanto os do Estado" (1996: 84). Na sequência, ele enfatiza que: i) "Identity is not a fact of society; it is a process of negotiation among people and interest groups “; e que ii) “... identity on not to be taken as an independent variable, tout court; it is often the outcome of a labelling process which reflects a conflict of interests at a political level" (1996: 85).

$\mathrm{Na}$ réplica, Buzan e Waever (1997) afirmam que não tomaram "sociedade" ou "identidade" como realidades objetivas, pura e simplesmente, mas que, para efeitos de análise, tomaram essas categorias tais como o são percebidas pelos seus atores securitizantes. Ora, se a identidade é algo passível de securitização, pode-se pressupor que ela possui um poder social de tal monta que torna sua invocação bastante eficiente, e um formato que torna o

\footnotetext{
${ }^{19}$ Para maiores detalhes sobre os conceitos e o debate, cf. Semprini (1999).

${ }^{20}$ Destaque dado pelo autor.
} 
discurso de segurança uma possibilidade real (1997: 244). Logo, fica claro que não importa o que de fato "sociedade" ou "identidade" possam vir a significar, mas sim como o são tomados pelos grupos que os securitizam. Se esses grupos conseguem "demonstrar" a existência de uma ameaça à sua sociedade ou identidade e obtêm sucesso na securitização, está fechado o circuito, pouco importando com quais conceitos ou categorias trabalham, e muito menos a validade dos mesmos.

Polêmicas à parte, é certo que a escola contribuiu - e segue contribuindo ${ }^{21}$ - em muito para o debate sobre segurança. Inclusive assiste-se, hoje, ao desenvolvimento de algumas de suas proposições por outros autores e centros de pesquisas. No caso da teoria de securitização, outras "escolas", tais como a de Paris e de Aberystwyth" ${ }^{22}$, estão avançando o debate a partir de perspectivas distintas das originalmente adotadas por Copenhague, o que é bastante interessante. Tendo encontrado o seu lugar nos domínios dos Estudos de Segurança Internacional, a Escola de Copenhague fornece um ferramental teórico bastante sofisticado e apropriado para todos aqueles que se dedicam a pensar o problema da segurança a partir de uma perspectiva mais abrangente.

\footnotetext{
${ }^{21}$ A última grande contribuição da Escola está em Buzan e Waever (2009), no qual eles introduzem a ideia de macrosecuritização associada ao conceito de constelações de segurança. Com isso, em síntese, eles vão além do nível médio de análise em direção ao nível de sistema, o que permite pensar a securitização em escala global. A Guerra Fria, por exemplo, na opinião dos autores, foi um caso bem-sucedido de macrosecuritização e, por enquanto, a "Guerra Global contra o Terror" vai alcançando um certo grau de sucesso.

${ }^{22}$ A Escola de Paris tem se destacado por desenvolver uma abordagem fortemente ancorada nas tradições teóricas de Bourdieu e de Foucault, buscando analisar tanto as práticas discursivas quanto as não-discursivas de segurança, com ênfase nos aparatos burocráticos e no uso intensivo de tecnologias de vigilância e controle, enquanto que a Escola de Aberystwyth (base dos Critical Security Studies) foca seus esforços na redefinição do campo dos Estudos de Segurança como um todo e, por consequência, no conceito de segurança, tendo como fundamento a ideia-chave de emancipação, tomada por empréstimo da Escola de Frankfurt.
} 


\section{CAPÍTULO II - A Fronteira Estados Unidos-México e o Choque de Narrativas}

"Seu Cristo é judeu. Seu carro é japonês. Sua pizza é italiana. Sua democracia, grega. Seu café, brasileiro. Seu feriado, turco. Seus algarismos, arábicos. Suas letras, latinas. Só o seu vizinho é estrangeiro"

(BAUMAN, 2005: 33, citando um cartaz comum nas ruas de Berlim em 1994)

\subsection{Construindo a fronteira sul}

Da Declaração de Independência (1776) até a consolidação de suas fronteiras terrestres, em meados do século XIX, os Estados Unidos estiveram focados em dois objetivos complementares: expansão territorial (rumo ao Oeste) e povoamento. Guiados pela ideia do Destino Manifesto, que trazia em seu bojo uma consciência de igualdade entre os colonos de origem anglo-saxônica, brancos e protestantes em oposição a outros povos europeus e de sua "inata superioridade" face aos povos indígenas e mexicanos, os colonizadores americanos conseguiram definir o mapa atual do país, com uma face voltada ao Atlântico e outra ao Pacífico, condição fundamental para que os EUA atingissem o status de potência já no final do século XIX.

O corpo ideológico do Destino Manifesto acabou gerando duas outras concepções tão ou mais poderosas que ele, as quais orientaram de modo mais preciso a política expansionista dos Estados Unidos, que são a Doutrina Monroe e o Corolário Polk. A Doutrina Monroe, enunciada em dezembro de 1823 pelo Presidente James Monroe, pode ser sintetizada em três proposições básicas, a saber: i) as Américas não estariam mais sujeitas às ingerências das potências europeias; ii) os Estados Unidos não interfeririam nas guerras entre as potências europeias; e iii) qualquer tentativa por parte dessas potências de estender seu sistema a alguma porção do Hemisfério seria encarada como uma ameaça à paz e segurança dos Estados Unidos. Em suma, é a ideia da “América para os americanos” (SMITH, 1994: 22-25). Um tanto quanto ambígua, a Doutrina Monroe geraria futuras e mais precisas interpretações, sempre adaptadas às necessidades expansionistas mais imediatas. Um exemplo disso é o Corolário Polk, que estabelecia que, caso uma ex-colônia europeia no Hemisfério quisesse se juntar aos Estados Unidos, isso seria decidido exclusivamente entre o povo da ex-colônia e o 
governo americano. Este corolário foi formulado pelo Presidente James Polk para justificar, depois da independência do México (1821), a anexação do Texas ${ }^{23}$ pelos EUA, em 1845.

Contudo, ainda em 1783, quando cessa a guerra de independência dos Estados Unidos (Tratado de Paris), estes assumem todo o território britânico na "América", passando a fazer fronteira com outras potências imperiais tais como França e Espanha ${ }^{24}$. Dada a sua necessidade de contínua expansão, os EUA passam a disputar com estas o domínio das suas possessões no Hemisfério, sendo o seu primeiro grande avanço a aquisição do território da Louisiana, comprado da França em 1803, manobra esta que praticamente dobrou o território dos EUA. A fronteira, agora, se restringia à Espanha, presente na atual região da Flórida e em quase todo o Oeste. No caso da Flórida, também houve a aquisição deste território por parte dos Estados Unidos (Tratado Adams-Onís, 1819), tendo o Tratado entrado em vigor em 1821.

Resolvida a questão no Leste, todas as atenções se voltaram para o Oeste, onde a presença espanhola ainda era significativa, em que pese o processo de decadência que o Império Espanhol vinha sofrendo.

Entra em cena, aqui, o México, que declara sua independência em 1821 e assume todo o território do Vice-Reino da Nova Espanha, desferindo um golpe mortal nos interesses espanhóis nas Américas pois, estimulados pelo exemplo mexicano, vários movimentos de independência logo tomariam corpo na América Central e do Sul.

Se o choque com os espanhóis era inevitável, com o nascente México não poderia ser diferente. Não bastasse a questão do Texas, para a qual o governo dos EUA concorreu direta e ativamente, os Estados Unidos seguiriam avançando sobre o México que, por sua vez, tinha enormes dificuldades para administrar e controlar o seu vasto território ao norte.

De acordo com Paul Ganster e David E. Lorey (2008: 25-26), a despeito dos esforços do governo mexicano no sentido de estabelecer laços políticos e comerciais de alta densidade entre o norte e a capital, buscando integrá-lo à vida da nação, a sua incapacidade em manter uma ordem política estável na região após o processo de independência acabou sendo o principal motivo que levou a região a um colapso administrativo. Alijada econômica e politicamente, com uma população não superior a 15.000 mexicanos e sem maiores laços identitários com o restante do país, o fato é que havia muito mais interesse em estruturar regimes autônomos locais do que em reforçar os laços com a capital.

\footnotetext{
${ }^{23} \mathrm{O}$ Texas, cuja ocupação e colonização por colonos de origem anglo-saxônica fora não somente autorizada como estimulada pelo próprio Império Espanhol, sublevou-se em 1824, tornando-se uma República em 1836. Finalmente, em 1845, o Texas foi anexado pelos Estados Unidos.

${ }^{24} \mathrm{~A}$ fronteira norte, disputada contra britânicos e franceses, não será objeto de análise, dados os objetivos do presente trabalho.
} 
Outros dois fatores contribuíram para esse posicionamento de viés autonomista. O primeiro é de caráter fundamentalmente político. Ora, de acordo com a Constituição de 1824 , o México se tornara uma república federativa de estados e territórios, tendo os primeiros um grau bastante elevado de autonomia decisória enquanto que os segundos ficavam sob controle direto do Congresso mexicano. Com isso, os territórios da Califórnia e do Novo México passaram a gozar de um status mais autonomista e, para piorar, o Congresso jamais legislou acerca da governança interna destes territórios, o que lhes conferia ampla margem de manobra. O Texas reagiu ferozmente a sua perda de influência quando, por disposição constitucional, foi unido a Coahuila (estado mais poderoso e mais populoso), surgindo assim o estado de Coahuila y Texas. Assim sendo, a perda de poder por parte do Texas, aliada ao alto grau de autonomia política da Califórnia e do Novo México, acabaram por lançar em terra fértil as sementes do separatismo.

Um segundo fator, de extrema importância, que ajudou a cindir o território do México foi o comércio. Ainda que as transações ditas "ilegais" com franceses, ingleses e norteamericanos já se davam sob o domínio espanhol, quando da independência do México (1821) as transações comerciais com estrangeiros passaram para a legalidade e, pouco tempo depois, já ficava claro que a maior parte das transações dos territórios ao norte do México se davam com os EUA e com a Europa, e não com o restante do país. Tais laços comerciais reforçaram a independência econômica da região face ao restante do México, além de os aproximar ainda mais dos Estados Unidos, que souberam explorar muito bem as tensões internas de um México dividido entre um estado centralizador, sediado na Cidade do México, e forças descentralizantes espalhadas ao norte, o que o tornava propenso a movimentos de secessão ou mesmo de conquista, uma vez que a ideologia do Destino Manifesto estava na ordem do dia.

Consoante o geógrafo Joseph Nevins (2010: 22-23), professor do renomado Vassar College, após a independência e posterior anexação do Texas pelos Estados Unidos (1845), ressurge uma antiga disputa fronteiriça, que se tornaria o gatilho da Guerra EUA-México (1846-1848): de acordo com os EUA, a fronteira sul do Texas se estendia até o Rio Grande, enquanto que, para o México, ela se situava a 150 milhas ao norte do Rio Nueces. Questão posta, não foi muito difícil para o presidente James Polk enviar tropas para a região, arrastando o México para uma guerra que lhe custaria muito. Polk queria não apenas que o México reconhecesse o Rio Grande como a fronteira natural do Texas mas - principalmente forçá-lo a ceder os territórios da Califórnia e do Novo México para os Estados Unidos, o que lhes daria acesso ao Oceano Pacífico e as imensas riquezas minerais situadas nessas regiões. 
Após dois anos de lutas e pesadas perdas, notadamente por parte do México, as tropas norte-americanas ocuparam a Cidade do México e a paz foi enfim assinada, dando origem ao Tratado de Guadalupe-Hidalgo, datado de 2 de fevereiro de 1848. Por este instrumento, nas palavras de Nevins (2010: 23):

[...] Mexico ceded about 40 percent of its territory to the United States, which annexed 1 million square miles of Mexican land, a territory equivalent in size to that of western Europe, and absorved 100,000 Mexican citizens and 200,000 Native Americans living in the annexed territory. All or part of 10 U.S. states resulted from the treaty: Texas, Arizona, New Mexico, Oklahoma, Wyoming, Colorado, Kansas, Utah, Nevada, and California.

É importante ressaltar que, entre a mera conquista territorial e a implementação de toda uma infraestrutura político-social para efetivar o controle sobre tal território, com a subsequente "americanização" de seus habitantes, vai uma distância muito considerável. A construção dos símbolos, dos significados, do sentimento de pertencimento e de exclusão ("nós" e "eles", "aqui" e "lác, etc.) faz parte de um processo maior, que busca estabelecer a ordem e o controle ao mesmo tempo que engendra processos de identificação e significação entre os habitantes. Em um sentido amplo, tudo isso pode se resumir ao termo "pacificação" (NEVINS, 2010: 23). Contudo, de pacífica a "pacificação" não tem nada, muito pelo contrário, notadamente nas primeiras décadas subsequentes ao Tratado. $\mathrm{O}$ emprego direto da violência, tanto por parte do Estado quanto por grupos civis era, até certo ponto, visto como natural. Nas precisas palavras de Nevins, "such violence - direct and systemic - is an integral element of the pacification process and remains so until significant ideological opposition to occupation disappears " (2010: 24). Contudo, o recurso à força não faz parte apenas dos processos de estabelecimento de ordem e controle territorial, mas também de identificação e significação ${ }^{25}$, o que é ainda mais perigoso, pois o "nós“ e "eles" pode facilmente degenerar para o "amigos" e "inimigos" (como de fato ocorreu).

Em termos históricos, muitas décadas foram necessárias para que os Estados Unidos de fato pacificassem a região da fronteira, levando "ordem e civilização" para uma região vista como "caótica e sem lei“". Evidentemente, a instabilidade na região fronteiriça era uma preocupação tanto dos EUA quanto do México mas, desde o início, nota-se um viés unilateral, por parte dos EUA, no tratamento da segurança da fronteira, e tensões eram lugar comum nas relações bilaterais, dado que, enquanto os Estados Unidos protegiam militarmente o seu lado

\footnotetext{
${ }^{25}$ Miguel Antonio Levario (2012) trabalha com precisão esse tema, que será analisado no Capítulo III, subitem 3.1 .
} 
da fronteira o México, sem as mesmas condições materiais, sofria com constantes ataques, vindos do território norte-americano, de tribos indígenas (engajadas no roubo de gado) e de filibusteiros os quais, baseados no Texas, tentavam tomar porções de território mexicano situado ao noroeste da fronteira, enquanto que os baseados na Califórnia lançavam seus ataques contra Sonora e a Baixa Califórnia. E de nada adiantavam as repetidas reclamações do México nem seus pedidos de cumprimento dos termos do Tratado ou mesmo da legislação norte-americana, uma vez que muitos dos criminosos eram cidadãos norte-americanos.

Ainda de acordo com Nevins (2010: 25-26), antes de se vislumbrar uma solução para tais problemas, os dois países precisavam resolver uma disputa derivada do Tratado de Guadalupe-Hidalgo. O ponto é que, graças a mapas extremamente imprecisos, não se tinha certeza da posição real da linha de fronteira entre o território do Novo México e os estados mexicanos de Sonora e Chihuahua. O governo expansionista dos EUA queria a fronteira o mais ao sul possível, de tal sorte a ter controle sobre uma área extremamente favorável para a instalação de uma ferrovia, além de acesso às minas da área de Mesilla. Com a agudização das tensões (o que envolveu até o envio de tropas), já que ambos Estados afirmavam possuir jurisdição sobre a área, o governo norte-americano decidiu por enviar James Gadsden para o local, na busca por uma solução pacífica.

Ao final, ficou acertada a compra da área pelos EUA, além da promessa de combate aos filibusteiros (promessa essa que o Senado dos EUA eliminou do texto do Tratado). Assim, em 1853 assinava-se o tratado denominado Gadsden Purchase (ou Tratado de la Mesilla), o qual encerrava as disputas fronteiriças entre os dois países, mas não as hostilidades de cunho étnico-racial e de classe que, a essa altura, já eram bastante evidentes na região da fronteira.

Posteriormente, James Gadsden foi imbuído de outra missão; e ele novamente obteve sucesso. Nas negociações com o então presidente Benito Juárez, ele conseguiu que o México concedesse aos Estados Unidos, através do Tratado McLane-Ocampo (1859), o direito de passagem perpétua pelo Istmo de Tehuantepec e pelo Golfo da Califórnia ${ }^{26}$, além de ter garantido sua colaboração bastante ativa para com a União, liderada por Abraham Lincoln, quando da Guerra de Secessão, principalmente através do fornecimento de serviços de informação e inteligência (VELÁZQUEZ; SCHIAVON, 2009: 06).

Por fim, vale ressaltar que, dada a imprecisão da cartografia da época, somada a um terreno particularmente problemático para se delimitar (desertos, rios que mudam de curso, etc.), além da imensa extensão da linha de fronteira (aproximadamente 2,000 milhas), duas

\footnotetext{
${ }^{26}$ Este Tratado, ao final, acabou não sendo ratificado pelo Senado norte-americano. Logo, nunca entrou em vigor, mas serve de exemplo acerca da intensa pressão diplomática a qual o México estava submetido, à época.
} 
realidades historicamente se contrapuseram: a da fronteira formal, a ser registrada nos mapas, e a da fronteira real, de difícil demarcação e, por conseguinte, controle. Enfatiza Rachel St. John (2013: 22) que, mesmo aqueles profissionais encarregados de estabelecer e fixar os marcos demarcatórios ao longo da linha de fronteira não tinham certeza da sua posição real. $\mathrm{Na}$ verdade, ninguém sabia na prática, por exemplo, por onde exatamente deveria passar a linha de fronteira entre o Novo México e Chihuahua, ou entre a Califórnia e a Baixa Califórnia. O que parecia simples, nos termos do Tratado, por vezes tornava-se uma missão impossível na prática.

Além das dificuldades técnicas, os demarcadores ainda tinham de lidar com os povos nativos que, na prática, controlavam a região, e que sequer haviam reconhecido a autoridade mexicana, agora substituída pela norte-americana. Por conta disso, os choques eram frequentes, o que colocava em risco a segurança das equipes e, mais ainda, demonstrava quem de fato possuía soberania sobre a área.

Isso posto, ficava claro, desde o início, que o estabelecimento territorial da fronteira, somado ao exercício da soberania estatal, não seria uma tarefa simples. Contudo, o que mais impressiona é o fato de que, em pouco mais de 160 anos, a fronteira Estados Unidos-México tenha se transmutado de um mero traçado na areia, na precisa formulação de St. John (2013), para um vasto complexo de segurança composto por muros, cercas e barreiras altamente vigiado e militarizado, algo bastante insólito para dois países que não somente vivem em paz como possuem profundos laços de caráter econômico-comercial. De fato, o paradoxo existente entre o Nafta e a "Cerca" é, sem dúvida, uma das maiores contradições existentes nas relações entre o México e os Estados Unidos, e o seu centro nervoso é justamente a fronteira.

\subsection{Construindo a identidade norte-americana}

\subsubsection{A ideia de nação}

O que é uma nação? Ora, ao menos desde a célebre conferência de Ernest Renan, proferida na Sorbonne (1882), as discussões sobre o sentido e a natureza da nação, do nacionalismo e, por conseguinte, da identidade nacional, ensejaram a produção de vastíssima bibliografia especializada, a qual ganhou novo ímpeto, nos dias atuais, por conta do advento do pós-Guerra Fria e do ressurgimento dos movimentos nacionalistas e ultra-nacionalistas principalmente, mas não apenas, no continente europeu. 
Para Renan, em sua clássica definição (2006: 19), a nação "é uma alma, um princípio espiritual", constituído por duas coisas que, no fundo, são uma só: i) a posse coletiva de um valioso legado de lembranças, de memórias, e ii) o consentimento, o desejo de viver em conjunto e perpetuar o valor da herança comum historicamente herdada. Simbolizando o ápice de um longo processo marcado por grandes esforços, sacrifícios e devoção, a nação é "um plebiscito diário, tal como a existência de um indivíduo é a afirmação perpétua da vida“. Logo, para o autor a nação é uma construção histórica, erigida sobre uma base voluntarista, que une passado e presente, cimentados pela memória histórica herdada e que deve ser perpetuada.

Assim como Renan, outros pensadores, tais como Ernest Gellner (2008), Benedict Anderson (2008) e Eric Hobsbawn (2011), por exemplo, também enxergam a nação como sendo uma construção histórica. Para Gellner (2008: 06), a nação é uma “contingência”, uma possibilidade, e "não uma necessidade universal", de modo que o "Estado certamente emergiria sem uma nação, assim como algumas nações emergiram sem as bênçãos e proteção de seu Estado". Contudo, a nação moderna, bem como o nacionalismo (tido por ele como um princípio político), foram construídos pelo Estado.

Benedict Anderson (2008: 32-34), por sua vez, define nação como sendo "uma comunidade política imaginada - e imaginada como sendo intrinsecamente limitada e, ao mesmo tempo, soberana". Ela é "imaginada" no sentido de que, mesmo nas menores nações, os seus membros jamais poderão se conhecer a todos, ainda que vivam em comunhão ("a nação é uma alma“, já dizia Renan); é limitada porque está circunscrita por fronteiras finitas que a separam de outra nação e, por fim, ela é soberana, e tem a sua liberdade garantida por um Estado igualmente soberano, que se firmou no momento em que as dinastias reais e a ordem divina perdiam a legitimidade face a ascensão do Estado territorial moderno.

Segundo Eric Hobsbawn (2011: 14), apesar dos esforços de boa parte da literatura especializada, não existe um critério satisfatório a partir do qual seja possível "enquadrar", por assim dizer, determinadas coletividades humanas na categoria de "nação". Por ser um fenômeno muito recente, o qual emergiu de conjunturas históricas particulares - regionais ou localizadas - não é possível, a priori, distinguir uma nação de outras coletividades. De um modo geral, as tentativas feitas apoiaram-se ou em critérios objetivos, ou em subjetivos.

Em termos objetivos, os critérios mais comumente utilizados para definir uma nação foram a língua, a etnia ou uma combinação de língua, território comum, herança comum, traços culturais comuns, etc. Já em termos subjetivos, os esforços foram dirigidos no sentido da busca por um senso de coletivo (ex.: "a nação é um plebiscito diário") ou de individualismo, "à moda austro-marxista de se considerar a nacionalidade como passível de 
aderir as pessoas, onde elas vivessem ou com quem vivessem, sobretudo se estas decidissem exigi-la" (HOBSBAWN, 2011: 16). O problema é que, tanto a abordagem coletivista quanto a individualista, no fundo, não passam de uma tentativa de se escapar da compulsão do objetivismo a priori, adaptando a definição de nação a territórios nos quais pessoas com diferentes línguas, etnias, etc., convivem. Elas explicam a posteriori o que é uma nação, além de ser um caso claro de excesso de voluntarismo.

A sorte da abordagem objetiva também não é das melhores. "Todas as definições objetivas - explica Hobsbawn (2011: 15) - falharam pela óbvia razão de que, dado que apenas alguns membros da ampla categoria de entidades que se ajustam a tais definições podem, em qualquer tempo, serem descritos como 'nações', sempre é possível descobrir exceções". Pode ocorrer, por exemplo, que um determinado caso que se enquadre na categoria de nação simplesmente não o seja, ou sequer tenha aspirações nacionais. Pior: pode ocorrer o surgimento de uma nação que não se enquadre nos critérios objetivos. Ora, como ajustar uma entidade historicamente nova, emergente, mutável, dentro de um quadro de referência dotado de suposta permanência e universalidade? Suposta, deve-se ressaltar, porque critérios tais como língua e etnia são, em si, “ambíguos, mutáveis, opacos e tão inúteis para os fins de orientação do viajante quanto o são as formas das nuvens se comparadas com a sinalização da terra" (HOBSBAWN, 2011: 15). Contudo, tais critérios se tornaram poderosas e convenientes ferramentas para fins propagandísticos e programáticos, mas não para fins descritivos.

Diante disso, se nenhuma das definições é satisfatória, como resolver o problema? Hobsbawn (2011: 18) trabalha com a hipótese de que nação é "qualquer corpo de pessoas suficientemente grande cujos membros consideram-se membros de uma "nação"”; uma definição basicamente política, também adotada por outros autores. Para ele, a palavra nação é utilizada de modo tão amplo e impreciso que o vocabulário tradicional do nacionalismo pode significar, hoje, quase nada. Se, para o nacionalismo, a nação pode ser reconhecida prospectivamente, a "nação real" só pode ser reconhecida a posteriori - e essa é a abordagem do autor. É uma abordagem atenta as mudanças e transformações do conceito, especialmente em relação ao fim do século XIX. Ora, dado que os conceitos são histórica, social e localmente enraizados, eles devem, portanto, ser explicados a partir destas realidades.

Tal como Gellner (2008), Hobsbawn (2011: 18) sustenta que o nacionalismo é um princípio político que deve ser suficientemente congruente de tal sorte a sustentar a unidade política nacional, agregando a este a implicação de que o dever político à organização política supera todas as outras obrigações públicas. Isso distingue o nacionalismo moderno de outras formas menos exigentes de identificação grupal ou nacional. 
Ele não considera a nação como uma entidade social originária ou imutável. Ao contrário, pensa que a nação pertence exclusivamente a um período particular e historicamente recente - a era moderna. Ela é uma entidade social apenas quando relacionada a uma forma de estado territorial moderno, o Estado-nação, e não faz sentido discutir nação e nacionalidade fora desse contexto. Com Gellner (2008), ele sublinha o elemento do artefato, da invenção, da engenharia social que entra na formação das nações. A nação é um mito; já o nacionalismo, que toma culturas preexistentes e as transforma em nações, algumas vezes as inventa e frequentemente oblitera culturas preexistentes. Portanto, para Hobsbawn (2011: 19), o nacionalismo vem antes das nações. As nações não formam os Estados e os nacionalismos; o que ocorre é justamente o oposto. Por fim, as nações são "fenômenos duais, construídos essencialmente pelo alto, mas que, no entanto, não podem ser compreendidas sem ser analisadas de baixo", ou seja, sem que se leve em conta os interesses das pessoas comuns; suas esperanças, necessidades, aspirações, interesses, etc., os quais não são necessariamente nacionais e menos ainda nacionalistas (2011: 20).

Vale ressaltar que o autor (2011: 45) desmistifica o discurso identitário de base essencialista ao enfatizar que, historicamente, etnicidade, língua ou mesmo uma história comum nunca foram critérios decisivos para a formação das nações; ao contrário, a formação dos Estados-nações na Europa do século XIX deu-se em um ambiente francamente heterogêneo, combinando diversas etnias e línguas em um mesmo território sob a autoridade de um Estado unificado. Elemento fundamental da ideologia liberal reinante à época, a nação simbolizava o ápice evolutivo de um sistema de organização social que, partindo das famílias, dos clãs e das tribos, agora confundia-se com a própria noção de progresso. Muito esclarecedoras, neste sentido, as palavras de Eric Hobsbawn (2011: 32-33):

De fato, se do ponto de vista revolucionário "a nação" tem algo em comum, não era, em qualquer sentido, a etnicidade, a língua ou o mais, mesmo que estas também pudessem ser indicação de vínculo coletivo. Como mostrou Pierre Vilar, o que caracterizava o povo-nação visto de baixo, era precisamente o fato de ele representar o interesse comum contra os interesses particulares e o bem comum contra o privilégio, como na verdade é sugerido pelo termo que os americanos usaram antes de 1800 para indicar a existência de nações, embora evitassem a própria palavra. Do ponto de vista revolucionário, as diferenças étnicas grupais eram tão secundárias quanto iriam ser mais tarde para os socialistas. Evidentemente, o que distinguia os colonos americanos do rei Jorge e seus seguidores não era a linguagem ou a etnicidade e, do mesmo modo, a República francesa não viu dificuldade alguma em eleger o anglo-americano Thomas Paine para a sua Assembéia Nacional. 
A nação revolucionária era, portanto, fundamentalmente cívica, e não étnica. "Assim considerada - esclarece o autor - a nação era o corpo de cidadãos cuja soberania coletiva os constituía como um Estado concebido como sua expressão política. Pois, fosse o que fosse uma nação, ela sempre incluiria o elemento da cidadania e da escolha ou participação de massa" (HOBSBAWN, 2011: 31). Aliás, Renan (2006), ao cristalizar a ideia de "plebiscito diário“, também enxerga a nação a partir de uma base cívica.

Nem na era do chamado "protonacionalismo popular" elementos tais como língua e etnia estavam presentes. Em termos linguísticos, sabe-se que não havia uma língua nacional antes da generalização da educação primária. "Em outras palavras - afirma Hobsbawn - a 'língua materna' real ou literal, isto é, o idioma aprendido pelos filhos de mães analfabetas e falado para o uso cotidiano, não era, em qualquer sentido, uma língua nacional” (2011: 70). Deste modo, as línguas nacionais são construções "semi-artificiais“ ou, por vezes, simplesmente criadas, sendo justamente o oposto do que a mitologia nacionalista pretende que sejam - as bases fundamentais da cultura nacional e as matrizes da mentalidade nacional. "Torna-se então claro que - continua Hobsbawn - exceto para os dominantes e para os instruídos, a língua dificilmente poderia ser um critério para a existência de uma nação (...) Onde muitas línguas coexistem, o multilinguismo pode ser tão normal que constitui, de modo bastante arbitrário, uma identificação exclusiva com qualquer idioma“ (2011: 73). O fato é que as línguas se multiplicaram com os Estados, e não o contrário, sentencia o autor.

Por derradeiro, em termos étnicos, em que pese a hipertrofiada importância que o nacionalismo étnico dá aos laços de sangue e parentesco, à descendência comum, etc., o fato é que a base crucial de um dado grupo étnico, como forma de organização social, é cultural, e não étnica ou biológica. Ora, as populações dos grandes Estados-nações territoriais são muito heterogêneas para que se possa reivindicar uma etnicidade comum, mesmo que se exclua o fenômeno da imigração moderna. A história demográfica de grande parte da Europa foi tal que sabe-se muito bem o quão multiforme pode ser a origem de alegados grupos étnicos (HOBSBAWN, 2011: 79). Assim colocado, a etnicidade não possui qualquer relação com o que se entende por nação ou mesmo Estado-nação. Agora, não se pode perder de vista que, embora a etnicidade não signifique, em termos reais, nada, ela foi um elemento muito importante para a formação do moderno nacionalismo, tendo sido ressuscitada, hodiernamente, por movimentos ultra-nacionalistas, que buscam estabelecer de um modo bastante claro as supostas distinções entre "nós" e "eles", ou ainda entre amigos e inimigos, com consequências que invariavelmente tendem ao desastre. 


\subsubsection{A narrativa da nação norte-americana}

Nada cristaliza com mais rigor a chamada narrativa da nação norte-americana que o “Jeremíada Americano", uma espécie de sermão político que se originou nos púlpitos europeus e foi sendo adotado e transformado, em sua forma e conteúdo, pelos puritanos da Nova Inglaterra, tendo atravessado os séculos e servindo, até hoje, como pilar do sonho e da mítica da excepcionalidade da nação - e do povo - norte-americano. Sem ele, o mito da América não seria tal como o é universalmente conhecido, tendo a sua retórica atendido a um largo conjunto de necessidades sociais, históricas, políticas e até psicológicas, da formação da nação até os dias que correm. É fato quer a "retórica puritana-americana", por assim dizer, permanece, em sua essência, basicamente a mesma desde os tempos do Mayflower até o pósOnze de Setembro, servindo como último lastro à condição da americanidade e de sua inata excepcionalidade.

Na interpretação de Sacvan Bercovitch (1978), professor da Universidade de Harvard, o Jeremíada sobreviveu ao declínio da Nova Inglaterra puritana e conseguiu se perpetuar no tempo porque logrou se tornar a retórica da cultura dominante; a essência do mito da América, e porque sua natureza dual (religiosa e política) serviu bem aos propósitos de um Estado intimamente ligado ao pensamento religioso, com a teologia atada à política e a política destinada a realizar o progresso e o "Reino de Deus na Terra".

Mas em que consiste exatamente este sermão, este jeremíada? Bercovitch (1978: 0330) reconstrói esta narrativa a partir de um ponto de vista bastante crítico e analítico. Assim, ele esclarece que, de acordo com o clássico texto, John Winthrop, a bordo do Arbella e no meio do Oceano Atlântico, foi o responsável por delinear as bases de uma "infante teocracia“ através de uma profecia bastante ominosa, afirmando que os passageiros do navio estavam, naquele momento, celebrando um pacto com Deus, e portanto, não deveriam esperar benesses imediatas, mas sim fazer por merecê-las. Invocando o precedente de Israel e do "povo escolhido“, Winthrop esclareceu que, doravante, Deus estaria atento aos movimentos de todos eles e, enquanto Ele lhes garantiria proteção, assistência e lhes tomaria como os Seus favoritos, caberia a essa pequena comunidade cumprir estritamente com os seus deveres; caso contrário, seriam alvo da "ira divina".

Semanas antes do embarque, em Southampton, os futuros passageiros já haviam sido admoestados por John Cotton, que ressaltou os graves perigos envolvidos na empreitada e que, se quisessem as bênçãos de Deus, deveriam viver para Ele. Assim, se os peregrinos caíssem em tentação, Deus os abandonaria de modo irrevogável. 
Ora, todos os elementos citados nos discursos de Winthrop e Cotton - pacto com o divino, quebra do pacto, degeneração dos mais jovens, o encantamento com os lucros e prazeres terrenos, a vingança divina - faziam parte dos típicos sermões do século XVII da Nova Inglaterra. Particularmente, os sermões políticos, que eram proferidos nos dias de celebrações da comunidade, acabaram sendo denominados de "jeremíadas". Ao tentar sintetizar política e teologia, eles se destinavam a servir de guia para a comunidade, cujas ações políticas deveriam estar em sintonia com os ditames religiosos. Assim posto, a grande missão (errand) dos puritanos na América, ao estabelecerem as primeiras colônias, era a de criar a "cidade na colina", que serviria de farol para toda a humanidade, dado que eles eram o povo escolhido por Deus para tal; logo, não seriam tolerados desvirtuamentos da missão, e suas vidas deveriam servir de exemplo daquilo que é bom e justo. Portanto, se caminhassem com retidão, em breve estariam autorizados a ditar os padrões de moral, as dimensões da justiça e o alcance e significado das leis humanas.

É curioso ressaltar que não apenas o significado de "missão" é um tanto quanto ambíguo (por exemplo, a missão pode ser em nome próprio, em nome de outrem ou mesmo transmutar-se ao longo do tempo) como o seu próprio conteúdo, e isto foi um grande problema para os puritanos. No início, eles se enxergavam como uma espécie de "posto avançado" da Reforma; nesses termos, a Nova Inglaterra seria um atalho para a edificação de uma nova nação cujas bases estariam assentadas no Anglicanismo. Mas, com o colapso do Protetorado de Cromwell (1660), eles se viram abandonados e isolados, tendo falhado na sua missão inicial. Daí partiram para uma segunda abordagem, buscando edificar o novo por conta própria, mas o que era uma utopia chocou-se com a realidade, e eles se sentiram duplamente abandonados. A literatura da auto-condenação alcançou o seu ápice; o mundo os esquecia, a colônia degenerava, o que era para ser a cidade na colina estava se tornando uma nova Sodoma.

Assim, com o declínio da Nova Inglaterra, a opção foi avançar na colonização e estabelecer novas cidades, mesmo porque o Jeremíada, apesar de seu tom grave, na sua versão adaptada e desenvolvida pela primeira geração de puritanos nascidos na América, é de um otimismo inabalável. E isso fez toda a diferença. Ao contrário do modelo de Winthrop, tradicional, no qual figura um Deus vingativo, na adaptação feita pela primeira geração o sucesso da empreitada dos peregrinos é inquestionável, e este será o seu destino. Como povo escolhido, não existe outra possibilidade que não a do seu sucesso, ao final do percurso, porque Deus está ao seu lado. No caso de algum desvio ao longo do caminho, a punição divina teria um caráter corretivo, e não destrutivo. A América, afinal, era a Terra Prometida, 
reservada por Deus para o seu novo povo escolhido. Ressalta o autor que, quando da fundação de Boston, os puritanos tinham a esperança de que suas plantações serviriam de cenário para a segunda vinda do Messias, tão convictos estavam de sua missão e da realidade da Nova Jerusalém que haviam fundado.

O Jeremíada Americano, bem pontua Bercovitch (1978: 09), possui sua própria retórica e visão de mundo. Na Europa, o jeremíada cumpria uma função político-social; se destinava a assuntos mundanos, aos problemas e adversidades dos homens e da cidade dos homens. Não exigia conversão, mas sim obediência moral e virtude cívica. Já a sua versão americana fundia o sagrado com o secular, sendo o seu propósito guiar o povo de Deus na Terra, auxiliando-o a cumprir com o seu destino, e guiar o puritano individualmente também, através da salvação. Ele não se destinava exclusivamente à cidade dos homens ou à de Deus, mas à "cidade americana de Deus". Assim visto, pode-se dizer que o Jeremíada Americano ajuda a contar a história profética da América, de um país que

[...] despite its arbitrary territorial limits, could read its destiny in its landscape, and a population that, despite its bewildering mixture of race and creed, could believe in something called an American mission, and could invest that patent fiction with all the emotional, spiritual, and intelectual appeal of a religious quest. (BERCOVITCH, 1978: 11).

Em suma, é uma terra de Don Quixotes, afirma com extrema propriedade o autor; de Walt Whitman e seu American Way; de Martin Luther King e sua denúncia da massiva violação do American Dream; do eterno debate acerca da identidade nacional, repleto de raiva e fé ardorosa; de Conservadores perseguindo socialistas, definidos como conspiradores contra o Sonho Americano; e de Liberais denunciando o capitalismo como uma traição ao ideário original e sagrado da América.

E o que dizer da missão (errand), de acordo com a nova interpretação dada pela primeira geração de puritanos nascidos na América? Para além da construção da cidade na colina, da Nova Jerusalém, a missão tornava-se sinônimo de progresso. Implicava, portanto, na conquista do wilderness (“território de Satã”) para o Reino de Deus. Estava aí justificada a expansão para o Oeste selvagem; a conquista de territórios e a luta contra nativos e mexicanos; e a abertura de uma larga frente pioneira (frontier), em contínua expansão, que sequer o Pacífico foi capaz de frear. 
Citando o clássico texto de Samuel Danforth $(1670)^{27}$, ministro e pregador puritano, Bercovitch (1978: 11-13) assevera que a missão era tomada, pelos colonos puritanos, como muito similar a de Moisés (que também enfrentou e cruzou o wilderness, liderando seu povo) e a de João Batista. Fica bastante claro, portanto, que para eles a missão era um contínuo, que ia da promessa à realização: de Moisés a João Batista a Danforth (que se via como um profeta); do Velho ao Novo Mundo; de Israel em Canaã à Israel na América; de Adão a Cristo ao Segundo Adão do Apocalispse.

Impressiona observar a estratégia política de Danforth, típica do Jeremíada Americano do século XVII: partindo das Escrituras, estabelece um conjunto de normas comunitárias; a seguir, um conjunto de condenações que versam sobre o estado atual da comunidade e, por fim, uma visão profética que revela as promessas de Deus, anuncia a Boa Nova e explica as lacunas entre os fatos concretos e a narrativa religiosa. Sua visão histórica é cíclica (surgimento, queda e redenção) mas também progressiva: a redenção sempre se dá em um patamar superior. Daí o destino inescapável da Nova Inglaterra: de colônia a província, de província a nação.

Em sendo o puritanismo um misto de teoria política e doutrina religiosa, a retórica puritana necessariamente precisava unir política e religião para se impor como ideologia dominante no Novo Mundo. E foi o refinamento desta fusão que a fez tão bem sucedida. Ademais, o declínio do puritanismo não significou o declínio da força da narrativa do Jeremíada, que foi se adaptando e modernizando até os dias atuais, sendo hoje uma espécie de consciência comum da classe média norte-americana. O processo de "americanização" das colônias na América não implicou no abandono do jeremíada; ao contrário, reforçou seu papel e influência, estando vivo "nos corações e mentes" dos norte-americanos. Os seus valores fundamentais continuam inalterados; afinal, a América é grande porque tem um dever sagrado a cumprir no mundo, e esta é a vontade de Deus. Ora, essa visão tem enormes consequências tanto em termos políticos, quanto econômicos, quanto culturais, afetando desde questões meramente locais até questões ligadas à política externa. É uma visão ubíqua e totalizante. No caso identitário, é patente que a divisão entre o "povo escolhido" e os outros povos enseja um enorme potencial para conflito, ainda mais se estes outros povos vivem no wilderness - ou abaixo dele.

\footnotetext{
${ }^{27}$ DANFORTH, Samuel. A Brief Recognition of New England's Errand into the Wilderness, 1670. Disponível em: $<$ http://digitalcommons.unl.edu/cgi/viewcontent.cgi?article=1038\&context=libraryscience $>$. Último acesso: $18 / 09 / 2013$.
} 


\subsection{Construindo a diferença}

\subsubsection{A narrativa da "ameaça latina"}

Enquanto a narrativa da nação informou a base da construção social do "nós" em sua versão mais firmemente enraizada no imaginário coletivo da América, as contra-narrativas que foram sendo construídas ao longo da história serviram sempre a um propósito comum: informar a construção social do "outro", o qual frequentemente é tomado como verdadeira ameaça à sua sobrevivência. Assim, a "nação narrada" tem a sua existência ameaçada, de tempos em tempos, por "inimigos narrados”, construídos com o único propósito de simbolizar e sintetizar uma hipotética "grande ameaça", a qual comporta um potencial destrutivo tal que pode, ao fim, exterminar a "nação imaginada". Foi assim, ao longo da história norteamericana, que os mitos da "ameaça linguística germânica", da "ameaça católica", da "ameaça migratória chinesa" (depois substituída pela "ameaça migratória japonesa"), dentre outros, foram se constituindo, elegendo ameaças e ajudando a formatar, com alto índice de sucesso, comportamentos sociais xenófobos, políticas restritivas (quando não abertamente discriminatórias) e legislações draconianas destinadas a combater e neutralizar, por assim dizer, as supostas ameaças do momento.

Segundo o professor da Universidade da Califórnia (Irvine), Leo Chavez (2013: 0304), a chamada "narrativa da ameaça latina" ${ }^{28}$ faz parte "da grande tradição do discurso alarmista acerca dos imigrantes e de seu (presumido) impacto negativo na sociedade" 29 . Onipresente e cada vez mais explícita, a "narrativa da ameaça latina" possui algumas características que a diferenciam de narrativas passadas porque, ao menos desde meados dos anos 1960, quando o fluxo migratório de latinos (basicamente mexicanos, com baixa participação de centro-americanos e praticamente nula a de sul-americanos) entrou em uma longa curva ascendente até a virada do século, os mexicanos - em particular - passaram a ser representados como a "quintessência do imigrante ilegal". Constituídos enquanto "ilegais/criminosos" desde a década de 1920 e enquanto "criminosos/inimigos" desde a de 1970, eles foram sendo paulatinamente colocados à margem da sociedade, tendo os seus direitos básicos negados (o que inclui a cidadania e os direitos dela derivados) e, por fim, elevados à categoria de "inimigo" por uma ampla rede de intelectuais, políticos e formadores

\footnotetext{
${ }^{28}$ É importante ressaltar que esta expressão foi cunhada pelo próprio Chavez.

${ }^{29}$ No original: "In this sense, the Latino Threat Narrative is part of a grand tradition of alarmist discourse about immigrants and their perceived negative impacts on society. "
} 
de opinião que encontraram na mídia o suporte fundamental para a divulgação em massa de todo o tipo de discurso obtuso que tem por base a narrativa, quando não simplesmente reverberam a própria, com novas cores e adereços.

Mas em que consiste essa narrativa? Basicamente, em um conjunto de proposições que são tomadas como auto-evidentes e verdadeiras, prescindindo, assim, de qualquer fundamentação teórica ou empírica, destinadas a explicar por completo a "questão latina" nos EUA e a revelar o "potencial destrutivo" que estes carregam para o seio da América. Assim colocado, tem-se, por exemplo, que os "latinos" ${ }^{30}$ não desejam se integrar social e culturalmente à nação norte-americana, ou mesmo não conseguem - são incapazes de fazê-lo; não desejam aprender a língua inglesa; as "latinas" são incapazes de controlar suas capacidades reprodutivas - o que implica no descontrole das taxas de natalidade e, mais impressionante, eles são parte de uma grande força invasora ${ }^{31}$ que, a partir do sul da fronteira, está determinada a reconquistar o território que um dia foi deles (o sudoeste americano) e, por fim, destruir a nação norte-americana e o american way of life. Seria cômico, não fosse trágico.

O que mais impressiona não é a narrativa em si, cujas origens remontam aos primeiros dias do estabelecimento da fronteira, mas sim a capacidade que possui em formatar mentalidades, comportamentos sociais, políticas e legislação. Não seria outra a base de recente lei do Arizona $^{32}$ que autoriza a polícia a deter e revistar qualquer pessoa no espaço público para averiguar seu "status migratório", um eufemismo que, na prática, autoriza a detenção e revista de qualquer pessoa que tenha a aparência de latina, dado que, provavelmente (assim pensou o legislador), esta pessoa está no país ilegalmente e, portanto, é uma criminosa.

No caso da narrativa, o papel da mídia foi e segue sendo fundamental para o seu vigor e para a sua inacreditável capacidade de convencimento (ainda que esta seja desprovida de qualquer sentido lógico). Esclarece Chavez (2013: 04-07) que, muito apropriadamente, Benedict Anderson (2008), ao discutir seu conceito de "comunidade imaginada", enfatiza a crucial importância da mídia impressa para a construção desta "comunidade", bem como para a construção de todas as subjetividades que serviram de esteio para a ascensão do

\footnotetext{
${ }^{30}$ Para a narrativa, latino é praticamente sinônimo de mexicano; seja este um migrante, tenha nascido nos EUA ou não ou mesmo seja um descendente direto de pais mexicanos; esteja ou não em situação regular, no que tange à documentação.

${ }^{31}$ É o famoso mito da Reconquista que, por mais absurdo que pareça, possui um vigor e uma força (pseudo) explicativa notável, ainda nos dias de hoje.

${ }^{32}$ Editada em 2010, esta lei acabou sendo parcialmente revogada pela Corte Suprema, mas permanence em vigor na sua essência. Ademais, inspirou a criação de mais de duas dezenas de leis semelhantes em vários estados dos EUA; na sua imensa maioria, situados na porção sul do país.
} 
nacionalismo e para a própria modernidade em si. Neste mesmo sentido, ele lembra que, de acordo com Jürgen Habermas (1986: 193-194), a esfera pública depende da circulação do que este chamou de "commodities impressas“. É a partir destes referenciais que Chavez avança a argumentação, esclarecendo que, através da mídia, a "narrativa da ameaça" alcançou um status de ubiquidade, permeando o grande espetáculo midiático que se tornou a questão da imigração nos Estados Unidos, em termos gerais, e dos migrantes indocumentados de origem mexicana - os "inimigos" -, que atravessam a fronteira de modo "ilegal" e assim o permanecem em solo norte-americano, constituindo verdadeira "ameaça" à nação e ao modo de vida americano.

Ao se referir aos espetáculos midiáticos relacionados ao tema da imigração, Chavez se vale da reflexão de Guy Debord (2007: 13) acerca da ideia do espetáculo. Para o pensador francês, "toda a vida das sociedades nas quais reinam as modernas condições de produção se apresenta como uma imensa acumulação de espetáculos. Tudo o que era vivido diretamente tornou-se uma representação". Assim posto, Chavez complementa afirmando que "os espetáculos midiáticos são atos produtivos que constroem o conhecimento acerca dos temas que se fazem presentes no mundo“(2013: 06). E é exatamente disso que se trata. As imagens consumidas dia e noite informam e ajudam a construir a compreensão que se tem das pessoas, dos lugares, dos eventos; do mundo, afinal. É o modo padrão de compreensão do mundo e das relações sociais na atualidade; é com base nisso que se decide - guardadas as devidas proporções - quem pertence e quem não pertence; quem é cidadão e quem não é; quem faz parte do "nós" e quem são os "outros".

É claro que todo o debate a respeito da nação, do pertencimento, da imigração e de temas correlatos não se reduz unicamente a um binarismo pautado pelo "espetáculo“; contudo, é bastante claro, segundo Chavez (2013: 06-07) que a cobertura feita pela mídia influencia o modo como a sociedade enxerga os imigrantes e até o modo como estes se enxergam, ao transformar uma visão de mundo padronizada e estigmatizada em um dado objetivo, quase um fato natural, cuja veracidade sequer necessita se posta à prova. Ao cobrir os eventos relacionados ao tema da imigração, ela dá voz a comentaristas, especialistas, fontes alegadamente bem informadas, e até a cidadãos comuns, sendo que todos estes muito frequentemente invocam e replicam as assertivas tomadas como verdade que compõem a "narrativa“ para justificar suas posições, argumentos e ações. Ora, ao produzir esse tipo de conhecimento, a mídia ajuda a construir as imagens daqueles que serão considerados membros legítimos da sociedade e daqueles que não o serão, os quais acabam, ao final, sendo marginalizados e estigmatizados como os "outros". 
Por derradeiro, o espetáculo midiático coisifica os latinos e, com isso, os desumaniza. Reduzidos a mera condição de coisa, perdem eventual apelo emocional (ou mesmo humanitário, em muitos casos) que poderiam suscitar, abrindo caminho para políticas e legislações cada vez mais restritivas, limitando ou mesmo impedindo sua integração no corpo social e obstaculizando sua mobilidade econômica. Desse modo, uma marcha de imigrantes em Los Angeles, por exemplo, tenderá a ser vista como uma movimentação caótica, perigosa e que incita ao confronto aberto, e nunca como um conjunto de seres humanos lutando por reconhecimento e dignidade.

Exemplos não faltam a respeito desse engajamento e do espetáculo midiático. A American Legion Magazine, em 1974, fez reportagem de capa (cujo sugestivo título era "Our Illegal Alien Problem”) acerca da "invasão" que os EUA estavam sofrendo por parte dos "illegal aliens" (basicamente mexicanos), todos determinados a "sugar" os recursos da nação e "destruir" sua alma norte-americana. E esse não foi um episódio isolado. Desde então, tais representações foram se tornando cada vez mais frequentes, contribuindo com o discurso alarmista acerca da imigração mexicana - legal e ilegal (CHAVEZ, 2013: 29). A US News and World Report também deu várias capas para o tema, ainda nos anos 1970, declarando explicitamente que os EUA perderam o controle das suas fronteiras e que os mexicanos são uma "força invasora". A Time Magazine, em 1983, lançou o alerta aos seus leitores de que Los Angeles estava sendo "invadida", em longa reportagem, sendo o "invasor" o mesmo de sempre, e deu reportagem de capa, em 2001, sobre o fim da fronteira com o México e o nascimento da "Amexica". Em 2004, a Business Week deu capa ao que denominaram "separatismo" que crescia na "nação hispânica" dentro dos EUA, a qual estaria emulando o modelo de Quebec. New Republic, New York Times, Washington Post e Los Angeles Times também colaboraram ativamente com a disseminação da narrativa, com mais intensidade entre os anos 1960 e 1990 (MASSEY; PREN, 2012, apud CHAVEZ, 2013: 35-36). Isso tudo apenas no caso da mídia impressa. Em se tratando de rádio, TV e, mais recentemente, internet, a difusão da narrativa faz-se em escala exponencial.

Políticos e intelectuais também ajudaram a disseminar a narrativa, legitimando-a aos olhos do público, e é longa a lista de publicações por eles assinadas (além de declarações públicas, discursos, entrevistas, etc.). Tome-se por exemplo o caso de Patrick J. Buchanan, conhecido político conservador dos EUA. Os títulos de seus dois livros mais conhecidos falam por si: Death of the West: How Dying Populations and Immigrant Invasions Imperil our Country and Civilization, e State of Emergency: The Third World Invasion and Conquest of America. Peter Brimelow, um inglês naturalizado norte-americano que já foi editor da 
Forbes e do Financial Post escreveu um dos "clássicos" que informam a narrativa nos dias atuais: Alien Nation. Aqui, o título também fala (e muito) por si. Arthur M. Schlesinger Jr., importante historiador e ferrenho crítico do multiculturalismo, publicou o influente best seller The Disuniting of America - Reflections on a Multicultural Society, no qual ele alerta para os perigos do separatismo causado por uma educação bilíngue (inglês/espanhol), pelo "culto à etnicidade" promovido pelos multiculturalistas ${ }^{33}$ e pelos efeitos desintegradores que poderão advir caso os imigrantes não sejam devidamente assimilados. O "modelo Quebec" é o seu maior pesadelo, pode-se dizer, e o elemento-chave para a desintegração da América, no fundo, são os mexicanos. Apesar de seu verniz liberal, no melhor estilo Harvard, ele não consegue disfarçar seu enviesado olhar acerca dos latino-americanos em geral e, com mais ênfase, dos mexicanos.

$\mathrm{O}$ caso de Samuel P. Huntington merece ser tratado à parte, dados tanto o seu status na academia quanto as polêmicas que costumava criar. No "Choque de Civilizações" (1997: $52)^{34}$ ele já deixava claro que a civilização latino-americana é diversa da ocidental, dado que sua evolução deu-se por um caminho bastante diferente do da Europa e da América do Norte, podendo ser classificada como uma "subcivilização" dentro da civilização ocidental; porém distinta desta, ou simplesmente uma outra civilização, que não sabe ao certo se pertence ou não ao Ocidente. Nesse contexto, a "linha de fratura" civilizacional entre a o Ocidente e a América Latina é, justamente, a fronteira Estados Unidos-México - o grande palco dos “espetáculos" em matéria de segurança aqui analisados e o locus, por excelência, do choque das civilizações latina e ocidental.

Posteriormente, ele eleva o tom, em um curto artigo, tentando demonstrar as razões pelas quais o México é um grande "problema" para os EUA, notadamente no caso da imigração. Para Huntington (2000: 20-22), os mexicanos não aceitam mais serem assimilados e não adotam os princípios do Credo Americano ${ }^{35}$, de modo que a "mexican immigration poses challenges to our policies and to our identity in a way nothing else has in the past". Cinco características distinguem o caso mexicano, a saber: i) contiguidade - o que reforça o caso da fronteira e é agravado pelas diferenças econômicas entre os dois países; ii) números os mexicanos constituem $27 \%$ do total de estrangeiros no país (dados de 1998), e continuam

\footnotetext{
${ }^{33}$ Ele é bastante claro ao afirmar que "The attack on the common American identity is the culmination of the cult of ethnicity. " (SCHLESINGER, 1998: 125).

${ }^{34}$ A teoria foi apresentada, inicialmente, em uma palestra no American Enterprise Institute (1992), tendo sido posteriormente melhor desenvolvida e publicada, sob a forma de artigo, na Foreign Affairs (1993). Dada a massiva repercussão, ele expandiu a argumentação e a publicou em formato de livro (1996).

${ }^{35}$ De acordo com Huntigton (2005: 66-69), o Credo funda-se nos princípios da dignidade da pessoa humana, da liberdade e da justiça; no individualismo, na democracia, no liberalismo político e nos valores protestantes, sendo um elemento fundamental da identidade norte-americana.
} 
chegando em largas quantidades; iii) ilegalidade - um fenômeno marcante do pós-1965 e tipicamente mexicano, que representam 62\% do total de ilegais no país (dados de 1995); iv) concentração - a imigração mexicana tem como destino final o sudoeste dos EUA, particularmente o sul da Califórnia, o que implica em "graves consequências" 36 ; e v) persistência - a onda migratória mexicana não tem prazo para acabar, sendo um fluxo constante de pessoas de uma mesma "etnia" vindo do Terceiro para o Primeiro Mundo.

Todos estes elementos, somados, explicam o caráter singular da imigração mexicana e os seus impactos nocivos; notadamente, o bilingualismo (já que eles se recusam a se assimilar e seguem falando espanhol) e a alta densidade "hispânica" no sul dos EUA, alterando importantes aspectos culturais e societários da América, além de seu percebido impacto em questões econômicas diversas. Ao final, ele arremata dizendo que: "Mexican immigration looms as a unique and disturbing challenge to our cultural integrity, our national identity, and potentially to our future as a country”. Não poderia ser mais claro, dispensando maiores comentários.

Não obstante, ele refina o discurso e o amplifica, em 2004, em um artigo intitulado "O Desafio Hispânico". Além de repisar o já dito anteriormente, ele acrescenta que o constante influxo de "migrantes hispânicos" (mexicanos, obviamente) ameaça dividir os Estados Unidos em dois povos, duas culturas e duas linguagens, dado que estes rejeitam a assimilação, o Credo e formam os seus próprios enclaves políticos e linguísticos por todo o sul dos EUA de Miami à Los Angeles. Em seus termos:

Continuation of this large immigration (without improved assimilation) could divide the United States into a country of two languages and two cultures. A few stable, prosperous democracies - such as Canada and Belgium - fit this pattern. The diferences in culture within these countries, however, do not approximate those between the United States and Mexico, and even in these countries language differences persist. Not many Anglo-Canadians are equally fluent in English and French, and the Canadian government has had to impose penalties to get its top civil servants to achieve dual fluency. Much the same lack of dual competence is true to Wallons and Flemings in Belgium. The transformation of the United States into a country like these would not necessarily be the end of the world; it would, however, be the end of America we have know for more than three centuries. Americans should not let that change happen unless they are convinced that this new nation would be a better one ${ }^{37}$ (HUNTINGTON, 2004).

\footnotetext{
${ }^{36}$ Ele não esclarece bem as tais consequências mas, posteriormente, fará referências explícitas ao "modelo Quebec", aos perigos do separatismo, à "mexicanização" do sul dos EUA e, por fim, à Reconquista.

${ }^{37}$ Grifo nosso.
} 
Por fim, em Who are We? (2005), sua grande obra dedicada ao problema mexicano e à suposta ameaça que paira sobre a identidade norte-americana, ele faz uma síntese de seu pensamento e prevê o fim da identidade americana e, por consequência, da própria ideia de América.

Citando literalmente a Escola de Copenhague e o conceito de segurança societal (2005: 180-181), ele assevera que "in the contemporary world, the greatest threat to the societal security of nations comes from immigration" e, posteriormente, deixa bem claro a sua posição afirmando que "Illegal immigration is, overwhelmingly, Mexican immigration (2005: 225) e, por fim, citando Clinton, afirma que:

In 1993 President Clinton declared the organized smuggling of peoples into the United States a "threat to national security". Illegal immigration is even more a threat to America's national security ( ... ) Nothing comparable has ocurred previously in the American experience.

Ele mesmo afirma que escreve este livro como um patriota e um acadêmico, donde se verifica que não conseguiu segurar suas emoções ao discorrer sobre o "fim da América", deixando o rigou acadêmico um tanto quanto de lado.

Ora, revendo o que foi exposto até aqui, poderia ser feita a seguinte provocação: estaria mesmo a humanidade mergulhada em um choque de civilizações, ou tal choque seria de narrativas?

Fechando o tema, pode-se afirmar que a narrativa é, portanto, o fundamento último, primordial, das práticas securitizantes que, ao menos desde meados dos anos 1970, estão se acumulando como que em camadas nos EUA e ganhando cada vez mais força e legitimidade face a opinião pública. Dado que tais práticas se apoiam em discursos securitizantes, cujo objeto referente é a nação norte-americana como um todo, vista por uma perspectiva essencialista - a pureza da identidade nacional - e a ameaça está materializada sobretudo na pessoa do imigrante mexicano indocumentado, tem-se que a narrativa é a matéria-prima de todos os atos de discurso (speech acts) que têm como objeto tal imigrante, via de regra denominado simplesmente de "latino". Logo, compreender a narrativa é fundamental para se compreender a lógica através da qual ela opera (por mais obtusa que seja), bem como as diversas práticas que dela derivam ou a têm como inspiração.

Apesar da ameaça latina ser colocada em termos nacionais, o locus do "combate", por assim dizer, é justamente a região da fronteira Estados Unidos-México a qual, por vezes e cada vez mais frequentemente, tem assumido a função de trincheira, destinada a guardar a 
nação norte-americana, o Credo, o american way of life e, por extensão, a civilização ocidental da "barbárie" encarnada pelos povos que vivem ao sul do Rio Grande. Lamentavelmente, os atos de discurso (speech acts), na região da fronteira, cada vez mais se metamorfoseiam em discursos de ódio (hate speeches), com gravíssimas consequências de caráter humano, para dizer o mínimo. 


\section{CAPÍTULO III - Ao Sul do Rio Grande, um Inimigo Conveniente}

"O medo dos bárbaros é o que ameaça
converter-nos em bárbaros. E o sofrimento
que vamos nos infligir irá superar aquele
que havia provocado nosso receio. A
história nos ensina: o remédio pode ser
pior que a enfermidade"

(TODOROV, 2010: 15)

\subsection{A longa construção do inimigo}

Estabelecida a fronteira, começam os processos de significação e identificação; agregação e separação. "Não há identidade sem fronteiras", assevera Michel Foucher (2009: 22). E ele vai mais além, com muita precisão:

A fronteira é, para o Estado, um teatro onde a legitimidade de seu poder é observada com atenção. Nada de mais desastroso para uma autoridade soberana do que ser acusada de ter perdido o controle de sua fronteira. Sua missão é de garantir a segurança. O limite serve de lugar metafórico à identidade nacional, étnica ou cívica, separando-nos dos outros. A função de representação é essencial: cada comunidade nacional possui seu próprio mapa mental, seu relato, sua história, seus mitos, seus lugares e seus lapsos de memória (2009: 25).

Pode-se aceitar, dentro dos devidos limites, que a garantia da segurança na fronteira envolva o uso da força; contudo, ao menos no caso em tela os processos de identificação e separação apoiaram-se, desde o início, na violência desregulada e na construção do "outro" (o "mexicano étnico") enquanto verdadeiro inimigo. Dessa forma, racismo e classismo combinaram-se, desde os primeiros dias da fronteira, em uma poção venenosa que alimentou uma série de atos violentos - quando não explicitamente bárbaros - cujo suporte estava em um discurso que constituía o "outro" enquanto ameaça. Uma vez percebida a ameaça, tomavase por legítima qualquer medida destinada a combatê-la, por mais fantasiosa que a alegada ameaça pudesse, de fato, ser.

O processo de militarização da fronteira, cujo ápice pode ser vislumbrado logo no após-Onze de Setembro mas, por conta da sua forte institucionalização e com o suporte adicional de políticas de segurança cada vez mais agressivas, ainda não deu mostras de arrefecimento (muito pelo contrário, aliás), teve o seu início no final do século XIX, pautando, 
desde então, o padrão das relações Estados Unidos-México e das relações entre norteamericanos e mexicanos ao longo da faixa de fronteira e acerca da problemática da fronteira.

Miguel Antonio Levario (2012), em fundamental estudo sobre a militarização da fronteira e a construção do "mexicano étnico" enquanto inimigo, afirma que a militarização, além de aprofundar divisões raciais e internacionais, ajudou a construir a imagem do mexicano como o "outro", cuja mera presença em território norte-americano por si só constitui uma ameaça, seja porque sua etnia ameaça a suposta (e francamente alegada, ainda nos dias de hoje) "homogeneidade étnica" da sociedade norte-americana, seja porque, enquanto trabalhador migrante, lá está para "roubar" o emprego de um legítimo trabalhador norte-americano (branco, evidentemente).

E a evolução da categorização foi bastante rápida, diga-se de passagem: se, no início, o mexicano era apenas um "non-white", em breve passaria a "non-american" e, com o acirramento das tensões de base étnico-racial ao longo da fronteira e dentro do território dos EUA, passaria a "enemy other" e, por fim, a "enemy of state", demandando uma forte estrutura vigilante e punitiva ainda na virada do século XIX para o XX.

Um outro aspecto que vale a pena destacar é a combinação, desde o início, das forças de defesa estatais com forças privadas - não apenas autorizadas como estimuladas pelo governo dos EUA - para a defesa da fronteira e o combate ao "inimigo", além da imposição da "lei e da ordem" a espaços territoriais entendidos como "desgovernados", sujeitos a toda sorte de eventos graças a presença ameaçadora dos "outros". Nota-se, portanto, que a interação público-privado em termos de segurança da fronteira, que tantos debates fomenta hoje, nada apresenta de novo: é apenas mais um capítulo da história da fronteira, onde as estruturas estatais responsáveis pelo law enforcement comumente se associam a empresas privadas de segurança e, quando não estimulam, permitem a livre atuação de grupos "vigilantes", com óbvias implicações humanas, sempre respondendo a determinadas percepções de ameaça (reais ou não) com atos agressivos.

A segregação racial e a vilificação do "mexicano étnico"; seja este um imigrante indocumentado em busca de emprego, seja um cidadão mexicano-americano pobre ${ }^{38}$, acabou sendo, nos tempos atuais, absorvida no plano discursivo pela ideia da "ameaça societal", ou seja, tanto a questão étnico-racial quanto a questão de classe foram entranhadas no discurso da ameaça societal, representada pela "invasão latina“ dos EUA, via de regra efetivada por imigrantes indocumentados que constituem, no seu conjunto, uma "grave ameaça à sociedade

\footnotetext{
${ }^{38} \mathrm{Em}$ termos mais precisos, este é considerado um "alien citizen" dado que, independentemente do seu status legal, sempre será visto (e tratado) como um estrangeiro, segundo Mae Ngai (2004: 25), apud Levario (2012: 02).
} 
norte-americana". Em termos mais simples, é a narrativa da "ameaça latina“, ameaça esta que, por mais absurda que seja, está sendo combatida na linha de fronteira, tornada trincheira.

Contudo, há de se ressaltar que a militarização, no início, foi tida como uma opção aceitável, pelas agências responsáveis pela aplicação da lei, dadas as necessidades de pacificação da região e de incorporá-la à economia nacional. Contudo, na prática, as coisas não saíram tão bem quanto o esperado, uma vez que o próprio termo "pacificação" abre margem para uma série de medidas nem sempre adequadas ao seu propósito inicial. Em muitos casos, a paz produzida foi uma paz de cemitério.

O caso dos Texas Rangers é bastante elucidativo. Parte essencial da mitologia do Velho Oeste, perpetuada pela indústria cinematográfica hollywoodiana, os Rangers foram constituídos enquanto força paramilitar em 1823, tendo rapidamente se tornado a principal força policial do Estado, assumindo a responsabilidade de manter a lei e a ordem de um modo bastante ostensivo, o que incluía a "pacificação" de povos nativos americanos e a segurança da fronteira do Texas com o México; fronteira esta que se expandia gradualmente, diga-se de passagem. Depois que o Texas se tornou República (1836), os Rangers continuaram a fazer a segurança da fronteira, tendo mantido as suas funções quando da incorporação do Texas aos EUA (1845). Na leitura de Levario (2012: 17), os Rangers utilizavam-se de métodos extremamente violentos tanto para estabelecer sua autoridade na região, pacificando-a e protegendo os assentamentos de colonos contra ataques dos nativos, quanto para integrá-la à nação, buscando apoiar o seu desenvolvimento econômico ${ }^{39}$. Desse modo, tanto os fenômenos da pacificação quanto da expansão econômica acabaram engedrando, em maior ou menor grau, conflitos raciais, o colapso das estruturas sociais mexicanas que haviam sido estabelecidas bem antes da chegada dos Rangers, o isolamento dos mexicanos na parte mais baixa do estrato social e, por fim, a chamada "americanização" da vida ao longo da faixa de fronteira.

Dados o isolamento da região, se contrastada com os nascentes centros urbanos dos EUA, e seu vasto e inóspito território, tem-se por certo, hoje, que os Rangers nunca conseguiram estabelecer sua autoridade de um modo perene e estável. Para piorar, os conflitos de base racial eram extremamente frequentes, uma vez que diferentes facções lutavam entre si para estabelecer o controle sobre um imenso território. Vários eventos dessa natureza podem ser citados, dentre eles, a Guerra do Sal, de San Elizario (1877), a "guerra particular" entre

\footnotetext{
${ }^{39}$ Esse apoio, na prática, significava proteger a propriedade privada e a vida dos colonizadores e rancheiros "brancos" da região, além de abrir espaço, na frente pioneira, para novos assentamentos, os quais seriam protegidos por eles de incursões de nativos e de "bandidos" mexicanos.
} 
Chico Cano e o Ranger Joe Sitters - o que demonstra até que ponto a individualização dos conflitos poderia chegar - e, por fim, o Porvenir Massacre (1918), cujos nefastos resultados ajudaram a cristalizar a imagem dos mexicanos como "enemy others". A consequência imediata disso foi o início de uma série de ataques a quaisquer mexicanos que os Rangers encontrassem pela frente, independentemente de serem culpados de algo ou não. A vilificação do chamado "mexicano étnico" tem aqui suas origens, notadamente na região do oeste do Texas, que é o ponto focal da análise de Levario (2012).

É certo que todos estes eventos tiveram por base profundas diferenças raciais, as quais acabaram se resolvendo em mortes e massacres, ajudando a consolidar a imagem do mexicano como o "outro“, o "indesejado“, estivesse ele de qualquer lado da fronteira - isso não importava. A "questão mexicana", pode-se dizer, começou como um caso de conflito racial que por vezes chegava ao ódio aberto, embasando toda a sorte de ações violentas e de ambos os lados, deve-se ressaltar. Tomados como inimigo comum pelos responsáveis pela aplicação da lei e por rancheiros "vigilantes", os mexicanos (e as comunidades de mexicanosamericanos) foram aos poucos sendo alienados do tecido social, postos à margem, sendo segregados em todos os níveis de interação social e política. Muito elucidativas, neste sentido, as palavras de Levario (2012: 36-37):

The skirmishes between the Rangers and bandits remained largely isolated but impactful events that were the by-product of complex alliances between ranchers, Mexican revolutionary factions, and American law enforcement. Throughout the early 1910s, however, their confrontations developed into an environment of extreme distrust and animosity. The Texas Rangers utilized humiliating and brutal tactics that, at times, Anglo residents accepted. Mexicans captured by Texas Rangers were often murdered before legally charged or tried in a court of law. Many Anglo residents in West Texas categorized Mexicans as bandits and potentially dangerous. By the mid-1910s, social relations in West Texas had become thoroughly racialized ${ }^{40}$.

Outro evento de grande importância para o acirramento dos ânimos na região da fronteira e para a construção do mexicano como verdadeiro "inimigo" foi o ataque de Francisco "Pancho" Villa a Columbus (Novo México), em 9 de março de 1916. Nesse episódio, ao menos dezesseis americanos foram mortos, e centenas de villistas foram feridos mortalmente. Este ataque não apenas entrincheirou de vez duas comunidades étnicas cujas relações já estavam bastante debilitadas mas também serviu, ao final, para consolidar os mexicanos como verdadeiros "inimigos"; uma ameaça aos Estados Unidos e ao seu povo de

\footnotetext{
${ }^{40}$ Grifo nosso.
} 
origem anglo-saxônica (os "americanos", cujo sinônimo mais usual seria simplesmente "brancos").

O aumento da militarização, ainda na virada do século, aguçou os conflitos raciais e encorajou atos de retaliação por parte de civis. Já em 1916, apesar dos reforços na militarização, a atmosfera geral de insegurança começou a levar civis a se armarem e se organizarem em grupos denominados "vigilantes", os quais ficaram conhecidos, à época, como Home Guards. Esses grupos passaram a identificar os mexicanos, coletivamente, como inimigos, e não observavam quaisquer tipos de protocolos militares ou - pior - não estavam sequer preocupados em distinguir culpados de inocentes. Considerados como ameaça, os "mexicanos étnicos" passaram a ser cada vez mais marginalizados dentro do território dos EUA, sofrendo com a violência militar (estatal) e civil (grupos armados).

Estes Home Guards, esclarece Levario (2012: 66-67), eram compostos por civis que, voluntariamente, se organizavam em unidades paramilitares com o alegado intuito de proteger suas comunidades de ataques e - o que é extremamente grave - garantir a aplicação da "justiça" através de métodos extralegais (por exemplo, linchamento ou execução sumária). O que mais espanta é que recebiam apoio do governo estadual, o que incluía armas e munição.

A perigosa interação entre os setores militar e civil ficou bem à mostra com a mobilização da Guarda Nacional (ativada em 1916) e a criação dos Home Guards após o ataque de Villa. Se a Revolução Mexicana (1910-20) atraiu as atenções do governo dos EUA para a sua fronteira sul, a incursão de Villa em território norte-americano gerou uma escalada na militarização da fronteira, a qual se desdobrou em um processo de institucionalização dos mecanismos de segurança e vigilância da mesma. Doravante, além das iniciativas de caráter local (civis e militares) e, eventualmente, estadual, seria o governo federal que mobilizaria recursos e planejaria com mais rigor as políticas de seguranca para a sua fronteira com o México. Evidentemente, o engajamento do governo federal ajudou a cristalizar a percepção comum do mexicano como inimigo, aguçando as tensões e aumentando os níveis de violência de lado a lado. A Expedição Pershing, desencadeada na sequência do ataque de Villa, somada à mobilização da Guarda Nacional como principal responsável pela segurança da fronteira e os Home Guards, destinados a garantir a integridade das propriedades e do território fronteiriço dos EUA (além de efetivar a "justiça" em casos envolvendo mexicanos), formaram um pólo atrativo, um "chamado ao dever", cujas ações em defesa da "América" tinham o condão de mobilizar cada vez mais pessoal para o front, com o fito de estabelecer a lei e a ordem em um território ameaçado pelo inimigo do sul. 
Os chamados "border trouble days", ou seja, a época dos conflitos na região da fronteira desencadeados pela Revolução Mexicana, exigiram, para sua efetiva pacificação, que as estruturas institucionais de vigilância e punição passassem para o controle federal (LEVARIO, 2012: 69), assumindo formas mais complexas porém tão ou mais violentas que as locais. A inabilidade da Guarda Nacional em resolver pacificamente as questões, em lidar com as hostilidades de base étnico-racial, em conter a violência desregulada por parte de rancheiros, vigilantes e grupos armados, somada ao papel intrinsecamente violento e disruptivo dos Home Guards levaram, ao final, à criação, dentro do território dos Estados Unidos, de duas comunidades étnicas bem delimitadas e separadas; de um lado, os americanos (brancos, descendentes fundamentalmente de anglo-saxônicos) e, de outro, os mexicanos (non-whites, pouco importanto de eram cidadãos norte-americanos ou não). $\mathrm{O}$ caso mais emblemático dessa natureza foi El Paso, cidade do Texas que foi literalmente dividida em duas partes. O mexicano étnico, nessas condições, além de ter sido posto à margem da sociedade, agora era tratado como inimigo do Estado não por rancheiros locais, mas pelo próprio governo dos EUA. Justiça racializada, violência gratuita e todo um conjunto de hostilidades passaram a ser a norma, o que, obviamente, afetou as relações México-Estados Unidos, dado que o México revolucionário passava a ser encarado como uma grave ameaça à soberania dos EUA. Portanto, a defesa da fronteira e dos norte-americanos ("whites") fazia-se imperiosa, custasse o que custasse. Os "non-whites" que cuidassem deles mesmos e aceitassem pacificamente a sua condição subalterna; do contrário, teriam problemas.

Por fim, é importante discutir um pouco o papel da Border Patrol, agência federal de law enforcement cuja relevância histórica, no que tange ao controle e segurança da fronteira, é inegável, ainda que suas práticas sejam, desde o início, bastante controversas.

O estabelecimento da United States Border Patrol, ou, simplesmente, Border Patrol, em 1924, através do Immigration $A c t^{41}$, foi a culminação de uma política duplamente orientada que tem suas raízes nos idos de 1882, com a aprovação do Chinese Exclusion Act, que visava restringir o fluxo migratório de chineses para os EUA ao mesmo tempo em que tentava regular o suprimento de mão de obra imigrante para as indústrias da mineração, ferrovias e agricultura, basicamente (LEVARIO: 2012, 95). Ou seja, é uma política que, ao mesmo tempo em que visava fechar a fronteira por questões de segurança e imigração ilegal, buscava abri-la para o ingresso de mão de obra barata - à requisição dos empregadores norteamericanos - e, mais recentemente, para os intensos fluxos comerciais da era pós-NAFTA.

\footnotetext{
${ }^{41}$ Também conhecido como Johnson-Reed Act (1924).
} 
À época do Chinese Exclusion, a fiscalização e aplicação da lei em questão cabia ao United States Customs Service, cujos oficiais patrulheiros eram, na sua maioria, Texas Rangers, sheriffs de condados fronteiriços e cowboys para tanto nomeados, sendo que os requisitos básicos para a seleção eram saber andar à cavalo e atirar. Curiosamente, apesar da vigilância se dar ao longo da linha da fronteira com o México, a imigração de mexicanos não despertava a atenção dos oficiais, dado que não existiam controles formais deste tipo de migração até o estabelecimento da Border Patrol (1924). Inclusive, a travessia entre El Paso e Ciudad Juárez, por exemplo, era algo corriqueiro e sem qualquer tipo de controle, em ambas as direções, até o irromper da Revolução Mexicana. Logo, os "ilegais“, neste momento, eram os chineses. Como o Customs Service também fiscalizava contrabando, em 1903, para desafogar um pouco suas tarefas, a questão da imigração ilegal passou para o Immigration Service, que não tardou a criar um órgão denominado Chinese Division e categorizar seus oficiais como Chinese Inspectors. Dada a vastidão da fronteira, é bastante óbvio que a fiscalização, na prática, era deveras ineficaz, e os chineses eram vistos por muitos (incluindo o pessoal da fiscalização), como "boas pessoas", "obedientes", "pacíficos", o que fazia com que o número de denúncias fosse quase nulo. No caso das apreensões, dada a sofisticação dos esquemas de tráfico de pessoas adotado pelos grupos que levavam os chineses até o território dos EUA, elas também eram baixas.

Porém, à medida em que a fiscalização ia se aprimorando, e as dificuldades de ingresso se tornando mais palpáveis, as indústrias e campos, antes dominados por trabalhadores chineses, começavam a operar com uma maioria de mexicanos e, até a Revolução (1910), estes não eram incomodados nem tinham seus fluxos obstados por agentes patrulheiros da fronteira. Entretanto, já em 1914, à vista da constatação do grande número de mexicanos trabalhando nos EUA e cruzando a fronteira diariamente (apesar das restrições pós-Revolução, tomadas em nome da segurança nacional), começou-se a falar em uma “invasão mexicana“, a qual tinha o potencial de piorar as questões raciais no sul dos EUA (LEVARIO: 2022, 97). A partir de então, grupos de "restricionistas", ao temerem pela quebra da homogeneidade étnica da população do Texas (principalmente), começaram a exigir políticas e legislações mais restritivas, que limitassem ao máximo o ingresso de mexicanos em solo americano. Contudo, nada foi feito até o ingresso dos EUA na Primeira Guerra Mundial (1917). A partir de então, temores acerca do ingresso de pessoas pertencentes a "povos inimigos" europeus levou a uma revisão do quadro político e normativo vigente mas, de início, a única modificação foi um endurecimento na legislação destinada a barrar os chineses (renomeados, agora, como "asiáticos"). No caso dos mexicanos, como eram 
necessários para uma agricultura em franca expansão, apesar das Immigration Law de $1917^{42}$ e 1918, na prática os oficiais da fronteira faziam "vista grossa" e não se preocupavam muito com eles.

A grande mudança veio com o estabelecimento da Border Patrol (1924), cujo diploma legislativo - o Immigration Act de 1924 - uniformizou leis e procedimentos de campo no que tange, principalmente, ao combate à imigração ilegal, e criou uma agência única (Border Patrol) destinada ao law enforcement e que responderia diretamente ao Immigration Bureau ${ }^{43}$, órgão subordinado ao Departament of Labor ${ }^{44}$ dos EUA. Contando inicialmente com apenas 450 oficiais, distribuídos entre as fronteiras dos EUA com o México e com o Canadá, além da costa da Flórida, na prática, eram mais um poder simbólico que real em seus primeiros dias. No caso da fronteira com o México, os oficiais da Border Patrol (ex-Texas Rangers e cowboys) tinham um único objetivo: "to catch aliens"; sejam europeus, chineses ou mexicanos.

Apesar deste passo institucional importante, no que se refere ao "combate" aos ilegais, muitos grupos restricionistas, tais como a Ku Klux Kan, exigiam mais restrições objetivando "to prevent America from becoming the melting pot or dumping ground of the world" (LEVARIO: 2012, 99). Nem a legislação das cotas (Quota Act) de 1921, nem o Immigration Act de 1924 (que endureceu as cotas e restrições) lhes parecia suficiente e, ao menos no Texas, a Kan possuía uma enorme influência em todos os círculos governamentais, donde poderia avançar suas propostas obtusas baseadas em critérios pseudo-nacionalistas e abertamente racistas.

Um novo problema, o contrabando de bebidas alcoólicas, aumentou as responsabilidades da Border Patrol a qual, por decorrência, passou por um processo de expansão, reforma e militarização nas décadas de 1920 e 1930, partindo para uma concentração de suas atividas na região da fronteira Estados Unidos-México. Ademais, o colapso causado pela quebra da Bolsa (1929) e a Grande Depressão, somado a uma atuação mais agressiva da Border Patrol, que paulatinamente aumentava seus índices de apreensão e deportação, e o apoio popular às políticas restricionistas, fizeram com que os fluxos migratórios caíssem dramaticamente. Vale notar que, nos idos dos anos 1930, praticamente nenhum mexicano conseguia visto de trabalho para os EUA, e aproximadamente 500.000

\footnotetext{
${ }^{42}$ Também conhecida como "Asiatic Barred Zone Act". Apesar no nome, também se destinava a restringir a entrada de mexicanos em território americano, mas sem grandes sucessos nessa questão em particular.

${ }^{43} \mathrm{Da}$ fusão deste órgão com o Naturalization Bureau, em 1933, surgiria o poderoso Immigration and Naturalization Service (INS). Posteriormente, o INS passaria a responder não mais ao Ministério do Trabalho, mas sim diretamente ao Departamento de Justiça.

${ }^{44}$ É o equivalente ao Ministério do Trabalho, no Brasil.
} 
mexicanos residentes nos EUA foram ou deportados ou retornaram ao México em bases voluntárias, dada a precariedade do mercado de trabalho. Com isso, os mexicanos, já nos anos 1930, estavam no centro dos debates acerca da política migratória dos Estados Unidos, debate este dominado por agressivas posições contrárias à presença de mexicanos não apenas no mercado laboral dos EUA, mas no seu território.

É claro que as ambiguidades na aplicação das políticas restricionistas nos anos $1920 \mathrm{e}$ 1930 também dificultaram a incorporação dos mexicanos já residentes nos EUA à sociedade. Vistos desde os tempos do estabelecimento da fronteira como os "outros", os "non-whites", estes foram assumindo diversos papéis ao longo do tempo; de indesejáveis a criminosos, de criminosos a inimigos. Com o início dos controles de fronteira, uma nova dicotomia era estabelecida: legais e ilegais, cindindo de famílias a comunidades inteiras. Se a vida já era dura para os chamados "legais“, para os recém-denominados "ilegais" ela seria muito pior, e a Border Patrol teve um importante papel na construção da figura do ilegal. Não era mais apenas uma questão de regular o número de trabalhadores estrangeiros no mercado laboral dos EUA; doravante, era impedir, a todo custo, que "ilegais“ adentrassem ao país e pusessem em risco sua segurança.

\subsubsection{Um recuo estratégico? O Programa Bracero}

Instituído durante a Segunda Guerra Mundial (1939-45) com o objetivo de resolver o problema da falta de mão de obra não-especializada que o setor agrícola dos Estados Unidos estava enfrentando, o Programa Bracero (1942-64) consistiu em um acordo bilateral entre os governos dos EUA e do México que previa um sistema de contratação temporária de trabalhadores mexicanos o qual, inicialmente, duraria de 1942 até o final da guerra. Contudo, o acordo acabou perdurando por 22 anos, tendo sido extinto apenas em 1964, além de ter movimentado um fluxo de aproximadamente 4,8 milhões de trabalhadores.

Sob os termos do acordo original (o de 1942), o contrato era firmado entre o trabalhador e o governo dos $\mathrm{EUA}^{45}$ sendo que este, na condição de empregador, ficava obrigado a arcar com os custos relativos ao transporte, moradia e repatriação - que se daria de forma automática após o término do contrato - do trabalhador (bracero), além de pagar a mesma faixa salarial paga aos trabalhadores domésticos e de garantir o emprego efetivo do

\footnotetext{
${ }^{45}$ Essa foi uma exigência do México dado que, só assim, haveria uma garantia - mínima que fosse - acerca das condições de trabalho, uma vez que os fazendeiros norte-americanos, historicamente, pagavam menos e ofereciam condições de trabalho inferiores aos mexicanos, quando comparados com trabalhadores norteamericanos (CAMÍN; MEYER, 2000: 259).
} 
bracero por, ao menos, $75 \%$ do tempo previsto em contrato, devendo pagar um salário de subsistência à este caso ficasse desempregado por até $25 \%$ do tempo previsto em contrato (MORGAN, 2004: 129-130). Por fim, é curioso salientar que o governo retinha $10 \%$ do salário do bracero, o qual ficaria depositado em um fundo de pensão e que somente poderia vir a ser resgatado após o retorno do bracero ao México, sendo esta uma das várias salvaguardas que o governo inseriu nos contratos visando garantir o retorno do trabalhador após o término do contrato. Provavelmente, a mais explícita era a que proibia terminantemente que as esposas e a família do bracero adentrassem ao país durante o período do seu contrato, o que os "motivaria“" a retornar ao México após o cumprimento do mesmo.

De acordo com Justin A. Chacón e Mike Davis (2006: 141), citando um documento da American Farm Bureau Federation, "trabalhadores mexicanos sem esposas e famílias ( ... ) podem muito bem atender aos nossos picos sazonais e, depois, retornar aos seus lares ( ... sem criar problemas sociais complicados $" 46$. Ora, o renomado escritor suíço Max Frisch foi preciso ao declarar, com extrema ironia, a respeito do programa de trabalho temporário (guest worker program) que a Suíça estabeleceu, em conjunto com a Alemanha e os Países Baixos, nos idos dos anos 1960-1970: "queríamos trabalhadores, mas recebemos pessoas“.

Embora o Programa garantisse, formalmente, o direito dos trabalhadores temporários à sindicalização, na prática isso era quase impossível. Os sindicatos norte-americanos não estavam interessados em organizar os braceros; quando estes decidiam se manifestar ou recebiam algum apoio para se sindicalizar, seus esforços eram suplantados pela poderosa aliança formada entre o governo e os proprietários rurais - os grandes beneficiários do Programa. O que interessava, de fato, é que os braceros trabalhassem o máximo possível pelos menores salários (em comparação com os ganhos de um trabalhador rural norteamericano) e sem maiores proteções ou garantias trabalhistas, sanitárias, etc. Vencido o contrato, que voltassem para o México, enquanto que os produtores rurais beneficiados pelo Programa tinham agora mão de obra barata, abundante, sem custos sociais e subsidiada, na sua maior parte, pelos contribuintes dos EUA.

Logo no após-Guerra, principalmente por conta da Public Law $78^{47}$, editada em julho de 1951, o governo dos EUA assumiu todo o controle do Programa, afastando o México que,

\footnotetext{
${ }^{46}$ Grifo nosso. No original: "Mexican workers, [braceros] unaccompanied by wives and families ... can fill our seasonal peaks and return home ... without creating difficult social problems."

${ }^{47}$ Em termos técnicos, esta lei foi uma emenda à chamada Lei da Agricultura de 1949, que havia meramente prorrogado a vigência do acordo original (1942). Projetada para vigorar por apenas dois anos (mas o foi até 1964), a Public Law 78 aplicava-se tanto a trabalhadores rurais nacionais (norte-americanos) quanto estrangeiros (mexicanos), e dava ao Secretary of Labor o poder de alocar recursos dentro do território dos EUA, cabendo a
} 
segundo o acordo original (1949), tinha o direito de fiscalizar o tratamento dispensado aos braceros em solo americano. Ademais, essa lei deu ao Departament of Labor poderes no sentido de ser, doravante, o contratante oficial de braceros para o setor agrícola dos Estados Unidos. Contudo, os contratos passaram a ser firmados individualmente entre o bracero e o proprietário agrícola, não sendo o governo mais responsável pela sua observância o que significava, na prática, que as garantias mínimas que o governo havia dado no início não se fariam mais presentes. Se, por um lado, o governo tornava-se o principal procurador do setor agrícola, garantindo-lhe uma oferta constante de trabalho barato e desregulado, por outro o setor agrícola passava a ditar as regras do jogo, tornando-se ele mesmo o responsável pela sua fiscalização (CHACÓN; DAVIS, 2006: 142) ${ }^{48}$. Logo, o não-cumprimento dos termos do contrato, tais como carga horária, salário e o equivalente ao "seguro-desemprego" (que antes era responsabilidade do governo), dentre tantos outros, passaram a ser a regra, junto com a precarização das condições de trabalho (que sequer eram minimamente razoáveis, mesmo no início). Por derradeiro, deve-se salientar que, por força dessa lei, aquele que contratasse um "estrangeiro indocumentado" (undocumented alien) ficaria de fora do Programa 49.

Note-se, portanto, que ainda em 1951 os efeitos dos "indocumentados" no mercado de trabalho já se fariam presentes, sendo estes apontados como um dos grandes problemas do Programa. Esclarece Morgan (2004: 131) que a Comissão sobre o Trabalho Migratório relatou, neste ano, que os abusos cometidos pelos proprietários rurais, somados a uma frouxa fiscalização, estavam contribuindo para a citada precarização e para o rebaixamento geral das condições de vida no campo. Além disso, o ineficiente controle da fronteira sul e as controversas políticas de legalização ${ }^{50}$ contidas no Programa estavam resultando em um aumento no número de "ilegais" nos EUA, sendo que a soma das forças de trabalho dos braceros e dos "ilegais" estariam pressionando para baixo os salários, prejudicando os trabalhadores norte-americanos.

Em 1954 o México tentou, uma última vez, renegociar o acordo, buscando mais garantias para os seus nacionais, no que foi rechaçado pelos EUA. Como resposta, tentaram impedir que os braceros cruzassem a fronteira, um empreendimento não só inútil como

ele decidir quais áreas possuíam trabalhadores americanos em quantidade suficiente e quais não, de modo a poder enviar os braceros necessários apenas às áreas-chave.

${ }^{48}$ No mesmo sentido: MORGAN, 2004: 130.

${ }^{49} \mathrm{Na}$ prática, tal dispositivo raramente era observado, tendo o "indocumentado" se tornado, ao longo so tempo, a regra, e não a exceção, no mercado de trabalho agrícola dos EUA.

${ }^{50}$ Era cada vez mais comum o procedimento conhecido por "drying out the wetbacks", através do qual os braceros, uma vez vencido os seus contratos, eram estimulados por seus empregadores a adentrar vários metros no território do México para, depois, voltarem como "ilegais", os quais seriam devidamente legalizados e teriam um novo contrato de trabalho, sob os auspícios do Programa. 
temerário, dados os confrontos que gerou. Daí em diante o México desistiu de aplicar controles emigratórios ao longo da fronteira (CAMÍN; MEYER, 2000: 260).

Contudo, a partir de maio de 1954 as autoridades migratórias dos Estados Unidos passaram a deter e deportar mexicanos indocumentados, alcançando um total de mais de meio milhão de trabalhadores, os quais foram apelidados jocosamente de "wetbacks". (CAMÍN; MEYER, 2000: 259). A Operação Wetback, como ficou conhecida, se estendeu por aproximadamente um ano e, apesar da ampla cobertura midiática que teve e das inúmeras denúncias de abusos e desrespeito aos direitos humanos dos trabalhadores apreendidos e deportados (não apenas mexicanos mas trabalhadores de outras nacionalidades também), ela foi considerada um "sucesso", tendo a opinião pública pouco se manifestado com relação aos abusos cometidos. Na avaliação de Avi Astor (2009), professor da Universidade de Michigan, esta operação foi o primeiro caso de securitização das migrações ocorrido em solo americano, dado que a questão migratória havia deixado o campo da política "normal" e adentrado ao da segurança, exigindo a tomada de medidas excepcionais com o intuito de solucionar a questão.

Entretanto, um exame mais detido da operação e das suas condicionantes históricas sugere que tal opinião é um tanto quanto prematura, dados que, em síntese: i) estava em curso um programa federal de guest worker, indicando a necessidade de mão de obra estrangeira que era recrutada com o aval do próprio Estado; ii) questões ligadas ao racismo (do estabelecimento da fronteira em diante) e ao classismo (no mínimo, do Bracero em diante) não se enquadram, à princípio, no quadro teórico da securitização - elas serão, posteriormente, entranhadas no discurso identitário, que vai pautar o processo de securitização, a partir do final dos anos 1970, fundado em uma suposta ameaça de ordem societal - é a narrativa da "ameaça latina"; e iii) ele não define com clareza os agentes securitizadores, não aponta a "audiência“" e nem esclarece qual era exatamente o speech act adotado. Isso posto, pode-se considerar a Operação Wetback uma verdadeira contradição; uma tentativa falha de responder a pressões contrárias ao uso de mão de obra barata e desregulada pela indústria agrícola do sul dos EUA ao mesmo tempo em que essa mesma indústria estimulava (e, por vezes, ajudava) os trabalhadores a adentrarem ilegalmente no país, "contratando-os" sem os encargos impostos pelo Programa Bracero. Os wetbacks, por assim dizer, não representavam uma ameaça a identidade nacional norte-americana, nem no plano do real, nem no do discurso; tampouco ameaçavam a ordem econômica ou o emprego dos norte-americanos; eles apenas incomodavam alguns grupos de interesses bem definidos - e pontuais. Daí a afirmar a existência de um processo de securitização vai um longo caminho, e não parece que isso se deu nos termos da Operação Wetback. 
Face ao exposto até o momento, teria sido o Programa Bracero uma espécie de "recuo estratégico" na luta contra o imigrante de origem latina, agora visto com melhores olhos, dado ter sido implementado ainda sob os auspícios da "política da boa vizinhança" (1933-1945) do Presidente Roosevelt? Ora, é patente que não houve recuo algum; os mexicanos continuavam a ser vistos como os "outros"; necessários e desejados pelo capital, enquanto mão de obra barata, desprezados e segregados pela sociedade e pelo Estado, que acabou criando, sob o nome de Programa Bracero, um novo "sistema de castas" (nas duras porém precisas palavras de Chacón e Davis, 2006: 145) nos Estados Unidos, que apartava os trabalhadores rurais norte-americanos, livres, protegidos pela lei e sindicalizados, dos mexicanos, “indesejáveis" porém necessários; braceros ou "ilegais“.

É importante salientar que, no que tange ao Programa em si, o México em muito se beneficiou dele. De fato, sua trajetória no sentido da industrialização e da urbanização, combinada com sucessivos aumentos na produção agrícola, acabou por catalisar um deslocamento em massa dos agricultores que se dedicavam à subsistência ou a pequena lavoura rumo às cidades que, por sua vez, não davam conta do excedente populacional. A válvula de escape, para o proletariado agrário que migrou para as cidades, estava em uma nova migração; desta vez, rumo aos EUA. Ora, para o México, exportar esse superávit populacional amenizava em muito os crescentes problemas sociais, além de ser bastante lucrativo. Durante a década de 1950, por exemplo, os braceros enviaram para casa (sob a forma das remessas) algo em torno de 30 milhões de dólares/ano, o que fazia do Programa Bracero a terceira maior indústria do México à época (CHACÓN; DAVIS, 2006: 145). Além disso, exportar trabalhadores para os EUA também aliviava as pressões no campo, cujas taxas de concentração fundiária só aumentavam, e diminuía os índices de desemprego geral da economia. Para completar, quando os trabalhadores decidissem retornar ao México, via de regra retornavam com novas habilidades, as quais poderiam ser utilizadas não apenas na agricultura mas também na indústria pecuária, na avicultura, dentre outras (MORGAN, 2004: 133).

Quanto ao papel e a dimensão dos "indocumentados" na indústria agrícola dos Estados Unidos, sabe-se que, por conta das exigências postas pelo Programa, a grande maioria dos candidatos a bracero era recusada. Desse modo, para cada bracero selecionado, outros sete não o eram, sendo muitos destes encorajados a atravessar a fronteira sem a devida documentação, e ainda assim encontravam trabalho ao lado dos braceros, seja nos campos, seja nas linhas de trem que eram construídas para escoar a produção agrícola e mineral. 
A grande vantagem posta pelos "indocumentados" é bastante clara: mesmo trabalho que os braceiros, mas sem burocracia. Dada a adversidade da sua condição, o "indocumentado" sequer podia protestar ou levantar a voz, e seu empregador não era obrigado a prover suas necessidades básicas, tal como ocorria com os braceros. Em suma: trabalho mais barato e sem qualquer regulamentação ou encargo. Ao tomarem ciência da lucratividade do negócio, os próprios proprietários rurais passaram a aliciar trabalhadores mexicanos para cruzar a fronteira e trabalhar para eles. Ao longo da história, estes trabalhadores foram saindo dos campos e se dirigindo a outros setores da economia, sempre sendo "bem recepcionados" pelos novos empregadores, ávidos por lucro fácil. Apenas entre os anos de 1947 e 1949, foram registrados 76,000 braceros nos campos, contra um total estimado de mais de 142,000 trabalhadores indocumentados. Nos anos 1960, três quartos da força de trabalho agrícola na Califórnia e no Texas consistia de uma mistura de braceros e indocumentados (CHACÓN; DAVIS, 2006: 145-146).

Com o final do Programa, em 1964, sobreveio uma nova legislação migratória que tornou bem mais difícil, para os mexicanos, obter autorização para entrar nos EUA legalmente. Esclarece Rachel St. John (2013: 203) que esta foi a primeira vez que os Estados Unidos aplicavam um sistema de cotas exclusivo para as Américas, com um teto de 120,000 permissões por ano. Ao mesmo tempo, as instabilidades políticas e econômicas levavam mexicanos e centro-americanos a buscar trabalho nos EUA, seja regularmente (o que poderia levar anos) ou irregularmente. Daí não causar espécie o fato de que o número de apreensões entre 1960 e 1978 ter subido de 71,000 para mais de um milhão.

\subsection{A Doutrina do Conflito de Baixa Intensidade chega à fronteira}

A partir de meados dos anos 1970, a questão do controle da fronteira com o México ressurge como um assunto altamente controverso na política e na sociedade norte-americana, amplificado por uma retórica sensacionalista que colocava, em pé de igualdade, os problemas ligados à imigração ilegal, ao tráfico internacional de drogas e até a ameaça terrorista como críticos na região da fronteira, demandando ações urgentes e extraordinárias para garantir a segurança nacional, ameaçada que estava por tais questões.

O problema dos imigrantes indocumentados - que de novo não tinha nada - passou a ser representado como constituindo uma grave ameaça à segurança nacional, atingindo seu ápice com a aprovação do Immigration Reform and Control Act (IRCA), em 1986, uma legislação bastante abrangente e que previa, dentre outras coisas, um aumento progressivo da 
militarização da fronteira, a aplicação de penas para aqueles que contratassem trabalhadores imigrantes indocumentados (o que criou um lucrativo mercado de Social Security cards falsos, vale ressaltar), tornou os agentes da Border Patrol também responsáveis pela fiscalização e implementação da legislação antidrogas na região da fronteira e, a contrario sensu, anistiou aproximadamente 2.8 milhões de imigrantes indocumentados, concedendo-lhes a cidadania norte-americana, em uma tentativa de amenizar a retórica de grupos organizados prómigrantes que haviam conquistado algum espaço na mídia e na política, antagonizando com os restricionistas e elevando a temperatura dos debates e dos confrontos. É muito importante sublinhar, aqui, o papel fundamental de organizações religiosas e de defesa dos direitos humanos nessa verdadeira queda de braço com restricionistas de todo o tipo ${ }^{51}$.

Com o imprescindível suporte da narrativa da "ameaça latina“, que ia ficando cada vez mais virulenta e amplificada (vide os confrontos e debates que levaram à aprovação do IRCA), o governo Reagan subiu o tom do discurso, relacionando o problema dos "ilegais" às políticas intervencionistas dos EUA na América Central. Nesses termos, era imperioso fortalecer a segurança da fronteira dado que, por conta do apoio às forças anticomunistas em ação na América Central, cedo ou tarde uma gigantesca onda de refugiados "invadiria" a América pela fronteira sul, buscando um porto seguro contra a "brutal repressão" dos comunistas.

Para fechar o quadro, logo após a aprovação do IRCA o tema do tráfico internacional de drogas passou a eclipsar a discussão sobre a política migratória, e agora este era o problema que demandava uma solução rápida, uma vez que representava grave ameaça à segurança nacional. Isso posto, não tardou para o governo Reagan declarar solenemente "guerra às drogas" 52 , 'guerra' esta que foi um elemento fundamental tanto da política interna de seu governo quanto da externa ${ }^{53}$. Por fim, a despeito da ausência de atividade terrorista na região da fronteira, Reagan declarou, em 1986, que "terrorists and subversives are just two days' driving time from Harlingen, Texas", em um discurso em rede nacional feito com o propósito de angariar apoio popular para sua política beligerante e intervencionista na América Central, colocando a questão do terrorismo na agenda do dia.

Nesse contexto, a imagem construída e divulgada da região da fronteira é a de uma área extremamente vulnerável e desprotegida, a qual demandaria medidas urgentes e

\footnotetext{
${ }^{51}$ O chamado Chicano civil rights movement, que surgiu durante a década de 1960 mas ganhou força nos anos 1970, acabou gerando uma contra-narrativa à "ameaça latina”, o que levou a um recrudescimento dos discursos e práticas dos dois lados, potencializando os conflitos sociais ao longo da região da fronteira. Daí os esforços contraditórios do governo federal no sentido de contentar ambas as partes a um mesmo tempo.

${ }^{52}$ Vale lembrar que o governo Ford, em 1974, já havia - na prática - securitizado a questão do tráfico internacional de drogas, que agora seria retomada pelo governo Reagan.

${ }^{53}$ Tempos depois, o governo Bush retomaria esse discurso, tendo dedicado seu primeiro pronunciamento televisionado à nação ao assunto (1989).
} 
extraordinárias para que sua segurança fosse garantida e, com isso, a "invasão dos ilegais" pudesse ser contida, a "guerra contra as drogas" vencida e a "ameaça terrorista" confinada ao sul da fronteira.

De acordo com Timothy J. Dunn (1997), professor da Universidade de Salisbury e autor de influente tese acerca da aplicação, pelo governo dos EUA, da Doutrina do Conflito de Baixa Intensidade (LIC, em sua sigla em inglês) à região da fronteira Estados UnidosMéxico a partir de meados dos anos $1970^{54}$, o que ocorreu de fato, neste período, foi uma "gradual militarização" da região da fronteira moldada pela aplicação da Doutrina do LIC. Contudo, no seu entender, o termo "militarização" deve ser empregado não nos termos usuais - tal como Levario (2012) o fez em sua obra - mas sim como significando "the use of military rethoric and ideology, as well as military tactics, strategy, technology, equipment and forces" (DUNN, 1997: 03). Ou seja, de um modo mais preciso, o termo "militarização" pode ser definido como o conjunto de medidas associadas à Doutrina do Conflito de Baixa Intensidade, que foi desenvolvida pelo Exército Norte-Americano, nos anos 1980, com vistas a permitir a condução de uma série de atividades destinadas a neutralizar possíveis ameaças, no chamado "Terceiro Mundo" "55 à segurança nacional dos EUA.

Em essência, a Doutrina do LIC visa estabelecer e manter o controle social de determinadas populações civis através do emprego de uma miríade de sofisticadas técnicas e medidas que se valerão da coordenação e integração dos trabalhos das forças militares, paramilitares e policiais. Neste contexto, é importante esclarecer que tanto as forças militares desempenharão tarefas policiais quanto as forças policiais se valerão de técnicas e recursos militares no desempenho de suas tarefas. Desnecessário dizer que isso tudo, em seu conjunto, levou (e segue levando) a um sem-número de graves violações aos direitos humanos das pessoas e populações afetadas pelo emprego da Doutrina.

Embora tenha emergido durante o governo Reagan, a Doutrina tem suas raízes na teoria de contrainsurgência desenvolvida ainda à época do governo Kennedy. Contudo, essa lógica específica de militarização foi muito questionada, nos anos 1970, pela alta cúpula das Forças Armadas dos EUA ${ }^{56}$, cujas preocupações estavam concentradas na possibilidade de um conflito em larga escala (convencional ou nuclear) com a União Soviética. A despeito disso, nos anos 1980 a Doutrina foi desenvolvida e aplicada com frequência tanto pelas

\footnotetext{
${ }^{54}$ Mais precisamente, seu estudo tem como marco temporal os anos de 1978 à 1992, que coincidem com os governos Carter, Reagan e Bush.

${ }^{55} \mathrm{Na}$ prática, o foco eram os movimentos revolucionários baseados em países da América Central.

${ }^{56}$ Notadamente, após a Guerra do Vietnã (1961-75).
} 
Forças Armadas quanto pelos órgãos de inteligência - a CIA, por exemplo - tendo alcançado um relativo grau de institucionalização já no início dos anos 1990 (DUNN, 1997: 20).

Por sua vez, o termo "conflito de baixa intensidade" foi oficialmente definido pelo Exército Norte-Americano, nos seguintes termos:

Low-intensity conflict is a limited politic-military struggle to achieve political, social, economic, or psychological objectives. It is often protracted and ranges from diplomatic, economic, and psycho-social pressures through terrorism and insurgency. Low-intensity conflict is generally confined to a geographic area and is often characterized by constraints on the weaponry, tactics, and level of violence. (US Army, 1983, apud DUNN, 1997: 20).

Pode-se notar, na definição supra, que o Exército usou uma linguagem um tanto vaga e imprecisa, o que permitiu sua aplicação a uma larga gama de ações militares, as quais incluíram, por exemplo, a invasão de Granada (1983), do Panamá (1989), o bombardeio da Líbia, em 1986, o envolvimento nos longos conflitos de El Salvador (1980-1992) e da Nicarágua (1980-1990), as operações antidrogas na Bolívia (1986), etc. Em suma, o “conflito de baixa intensidade" é uma "war for all seasons" (DUNN, 1997: 21), e ele acabou, ao final, levando a um progressivo envolvimento das Forças Armadas dos EUA em assuntos que não são propriamente militares por natureza.

De acordo com um longo estudo de documentos do Pentágono relativos ao tema, Michael T. Klare (1988: 55-56, apud DUNN, 1997: 21-22), concluiu que o "conflito de baixa intensidade", em seus aspectos prático-operacionais, engloba seis principais "mission areas", a saber:

i) Foreign internal defense: Counterinsurgency and related actions to aid governments allied with the United States in their efforts to combat insurgent threats.

ii) Proinsurgency: The sponsorship and support of anticommunist insurgencies against third-world governments considered hostile to US security interests.

iii) Peacetime contingency operations: Short-term, rapid military activities taken in support of US policy, such as show-of-force operations, rescue missions, and punitive strikes.

iv) Terrorism counteraction: Defensive and offensive measures ("antiterrorism" and "counterterrorism", respectively) taken by the armed forces to prevent and conter terrorism.

v) Antidrug operations: The use of US military resources to curb the flow of illegal drugs into the United States and to attack and destroy sources of illegal drugs in foreign countries. 
vi) Peacekeeping operations: The use of US military forces to police cease-fires or to stablish a buffer zone between hostile armies.

Assim colocado, tem-se que ao menos quatro dessas áreas são significativas para se compreender as políticas de segurança para a fronteira sul, sendo elas: i) contrainsurgência (também denominada de foreign internal defense); ii) operações antidrogas; iii) terrorism counteraction; e iv) peacetime contingency operations.

A área de contrainsurgência é a mais bem desenvolvida, nos termos da Doutrina do LIC, tendo tido seu início, como já visto, em meados dos anos 1960. Focada prioritariamente na contenção de atividades e movimentos revolucionários - notadamente, na América Central - ela foi delineada de tal sorte a mobilizar recursos militares e de segurança em geral para neutralizar o chamado "inimigo interno", ou seja, aquele que representa uma grave ameaça à segurança nacional e que está fisicamente localizado dentro do território da nação. Em decorrência disso, o inimigo pode ser tanto uma pessoa, um grupo ou mesmo uma população inteira; pode ter um caráter militar, paramilitar ou civil. Ora, o discurso da Reconquista, se levado ao seu extremo, justificaria medidas extraordinárias até contra populações civis, formadas por mexicanos étnicos e mexicano-americanos, em situação de legalidade ou não, que habitassem a região da fronteira e supostamente "conspirassem" contra a integridade territorial dos EUA.

Contudo, em termos mais factíveis, as medidas de contrainsurgência, na prática, levaram a situações de repressão, abuso dos direitos humanos e, em seu limite, à formação de “esquadrões da morte", destinados a garantir a ordem e o controle social de áreas convulsivas via execuções sumárias e uma política de terror (físico e psicológico).

Um útimo ponto a ser destacado nesta seara é a integração de forças policiais, militares e paramilitares com o objetivo de "cumprir a missão", sendo os oficiais treinados para agir e pensar como militares em combate, e não apenas como agentes da lei. Isso se justificava, no início, sob o argumento da imperiosa necessidade de conter o "avanço do comunismo" e de seus agentes, que poderiam cruzar a fronteira do México com os EUA e, em solo americano, conspirar contra a nação. Mais uma vez, o vago discurso da "segurança nacional" serviria para justificar uma ampla gama de medidas, das mais inofensivas às mais brutais.

No caso das operações antidrogas, Dunn (1997: 25) esclarece que essa é uma área das mais relevantes no que tange à aplicação da Doutrina à região da fronteira Estados UnidosMéxico desde, ao menos, a edição da National Security Decision Directive (1986) pelo governo Reagan, o qual formalmente declarou que o tráfico ilegal de drogas consistia em uma ameaça à segurança nacional dos EUA. Ainda que as medidas destinadas ao combate ao 
tráfico na região da fronteira sejam bem anteriores à Diretiva, esta expandiu em larga escala o papel dos militares em tal combate, inclusive autorizando o Departamento de Defesa a se envolver diretamente em uma série de ações antidrogas. É certo que os militares ofereceram uma boa resistência a tal politica, notadamente antes do final da Guerra Fria, alegando que tais atividades eram típicas das forças policiais, e não militares, e que seu pessoal e equipamento não poderia ser realocado de áreas do domínio exclusivo das Forças Armadas para uma atividade meramente policial. Contudo, acabaram mudando de posição no pósGuerra Fria.

Em se tratando da área denominada de terrorism counteraction, a qual engloba operações de caráter defensivo e ofensivo, uma outra Diretiva presidencial (a National Security Decision Directive, de 1984), também declarou o terrorismo como "ameaça nacional" e engajou os militares no seu combate, prevendo que as convulsões na América Central pudessem, de alguma forma, reverberar dentro do território dos Estados Unidos, e o único acesso possível para "insurgentes, guerrilheiros, extremistas e terroristas" seria através da fronteira com o México.

Por fim, as chamadas peacetime contingency operations deixam suficientemente claro, dada a sua natureza ampla, difusa e ambígua, que a Doutrina poderia ser invocada para tratar de praticamente qualquer assunto que tivesse alguma ligação, por mais remota que fosse, com o tema da segurança - incluindo, aqui, o "gerenciamento" da fronteira e das populações fronteiriças por parte dos esforços cooperativos entre agências civis e militares, cada vez mais interrelacionadas quando se trata de assuntos de segurança (DUNN, 1997: 26-27).

Fica claro, de todo o exposto, que a Doutrina da LIC acabou gerando, em maior ou menor grau, uma certa militarização das sociedades onde ela foi aplicada (incluindo os EUA), e isto abriu caminho para um controle mais incisivo de populações civis tidas como "alvo" no caso dos EUA, os "latinos" em geral e os habitantes da região fronteiriça - de modo a assegurar que tais populações não investissem contra "a lei e a ordem" postas pelo Estado, nem se rebelassem contra injustiças ou problemas de ordem social ou mesmo política.

Ademais, todos os esforços de viés militar empreendidos ao longo da fronteira serviram a um triplo propósito: barrar os fluxos de imigrantes ilegais, de drogas e de traficantes, e de eventuais "terroristas" ou algo do gênero que, por ventura, deixariam a América Central e adentrariam aos EUA em busca de vingança. Na prática, como nenhum caso de terrorismo/terrorista foi documentado, a militarização serviu para "neutralizar", na medida do possível, a imigração ilegal e o tráfico de drogas, sendo que os custos humanos das 
operações, salienta Timothy J. Dunn (1997: 31), foram sumariamente desprezados, uma vez que elas se justificavam, de acordo com por conta do imperativo da "segurança nacional".

À guisa de conclusão, pode-se afirmar que, de fato, durante o marco temporal selecionado pelo autor (1978-1992), o qual compreendeu um governo Democrata (Carter) seguido de dois governos Republicanos (Reagan e Bush), houve uma aplicação bastante extensiva e consistente da Doutrina do LIC na região da fronteira Estados Unidos-México o que implicou, dentre outra coisas, em um crescente processo de militarização e institucionalização desta militarização, sob a alegação de que tanto a imigração ilegal, quanto o tráfico de drogas quanto um suposto perigo terrorista representavam uma grave e iminente ameaça à segurança nacional, demandando, portanto, medidas extraordinárias para a proteção dos EUA e de seu povo. Ainda que a militarização da fronteira seja decorrente de um longo processo histórico cujo início data dos primeiros dias do seu estabelecimento oficial, é bastante seguro afirmar que, no período analisado por Dunn (1997), esse processo assumiu uma nova dinâmica, sendo agora liderado pelo governo federal, conduzido por agências federais em colaboração com os poderes regionais e locais, francamente militarizado e apoiado por uma "retórica do medo", a qual nivelava imigrantes de origem latina, narcotraficantes e terroristas em um mesmo plano, sendo todos submetidos de maneira uniforme aos rigores de um complexo sistema de vigilância, controle e punição que, além de empregar equipamentos militares da mais alta geração, também empregava técnicas, táticas, estratégias e tecnologias desenhadas para o campo de batalha. Nesses termos, a Doutrina da LIC e sua rigorosa aplicação para supostamente solucionar os problemas de segurança percebidos ao longo da região da fronteira constituiu-se no eixo fundamental do processo de securitização das migrações, sendo o seu foco o imigrante mexicano indocumentado, tido como um "inimigo", uma "ameaça à segurança nacional”. Esclarecedoras, neste sentido, as palavras de Timothy J. Dunn (1997: 162-163):

The construction of an "enemy", or at least the designation of a looming threat, was central to the implementation of the militarization of the border. In the contemporary period, undocumented immigration was characterized as a potential threat to US "national security" and illegal drug trafficking was described as an actual threat, which implied that undocumented immigrants and drug traffickers were both "the enemy", either potentially or in fact. Given that related enforcement efforts in the border region were aimed primarily at Mexican-origin peoples, the process appears to have some continuity with the hostile practices of earlier periods that were focused on the same general population in the border region."

\footnotetext{
${ }^{57}$ Grifos nossos.
} 
Essa "primeira onda de securitização", por assim dizer, além de seus elementos tradicionais, teve a sua materialidade garantida pela aplicação da Doutrina do LIC para a questão da imigração ilegal - o que gerou a militarização e o recrudescimento das políticas e teve no Immigration and Naturalization Service (INS) o centro nervoso de todas as operações.

Aliás, o INS teve seu orçamento elevado em 240\% no período 1978-1992 (DUNN, 1997: 149), justamente para garantir o enforcement das operações antidrogas, "antimigrante ilegal" e "antiterrorista". Além disso, o símbolo mais visível da paranoia com relação à alegada insegurança da fronteira - as barreiras físicas - tiveram uma grande expansão no marco das ações da Doutrina. Ainda nos anos 1970, o INS construiu cercas de mais de três metros de altura em quatro setores vigiados pela Border Patrol que, a despeito disso, funcionavam como "corredores de acesso", para os imigrantes indocumentados, ao território dos EUA. E entre 1991 e 1992, a cerca que separa Tijuana de San Diego foi reformada, reforçada e expandida por construtores ligados às Forças Armadas que, além disso, avançaram mar adentro (cerca de doze quilômetros) com a instalação de enormes vigas de aço muito próximas umas das outras - era a Cerca se expandindo para o mar.

No plano analítico, é bastante claro que, no que tange ao objeto referente, este é a identidade norte-americana (tomada nos marcos do essencialismo); o agente securitizador por excelência é o próprio Estado, cuja atuação se dá via agências especializadas (por exemplo: INS, Border Patrol, etc.) e que, inclusive, conta com o apoio de uma ampla rede de acadêmicos, politicos, formadores de opinião, personalidades midiáticas, etc., que difundem, reforçam e hipertrofiam a narrativa da "ameaça latina", que constitui a essência ideológica do speech act que se materializa, não raro, em declarações oficiais, políticas e legislações. Entranhados no discurso da ameaça estão antigas questões de ordem racial, classista e xenófoba, que se fundiram sob a bandeira da defesa da identidade nacional. A audiência constitui-se, primordialmente, na população de origem anglo-saxônica que habita a região da fronteira e, não menos comum, os estados fronteiriços, e que não apenas "compra" o discurso da ameaça como exige que o governo as proteja da "invasão latina".

\subsection{O pós-Guerra Fria}


A partir dos anos 1990, um conjunto de operações especiais e "espetaculares", no sentido debordiano do termo, redefiniram a estratégia de combate aos "ilegais" na região da fronteira, alterando o modus operandi mas mantendo seu antigo viés segregacionista e racista.

Esta nova abordagem também ajudou a remodelar a paisagem da fronteira, por assim dizer - tanto a real quanto a imaginária - sendo que, menos de um ano após a implementação da $1^{\text {a }}$ operação, na região de El Paso, a opinião pública norte-americana em geral concordava com a premissa de que os EUA "estavam mais seguros” e a fronteira Estados Unidos-México, antes vista como "desgovernada" e "caótica", sob efetivo controle do Estado ${ }^{58}$. O segredo de tal sucesso, entretanto, estava muito mais no modo como as operações foram veiculadas e "vendidas" para a população em geral - que "comprou" de bom grado a ideia - do que na suposta eficácia das mesmas.

Maior responsável pela parte operacional de tais "operações especiais", a Border Patrol implementou quatro operações de larga escala, na década de 1990, justamente nas regiões tradicionalmente conhecidas como "border crossing points", a saber: El Paso, San Diego, Nogales e Brownsville; primeiro nas cidades-sede, depois se espalhando pelos seus arredores e regiões afins alcançando, em sua plenitude, boa parte das áreas mais utilizadas pelos "indocumentados" para fins de travessia.

Em termos teóricos, a grande novidade foi o emprego da estratégia conhecida por "prevention through deterrence". Consoante Peter Andreas (2009: 92), professor de Ciência Política da Universidade de Brown, tal estratégia foi desenvolvida pelo INS, nos idos de 1993-1994, com o intuito de inibir a entrada "ilegal" o que, se bem sucedida, evitaria o desgaste político causado pelas apreensões de "ilegais" em solo americano - sem contar as inúmeras denúncias de violações aos direitos humanos decorrentes de tais práticas - e os danos à imagem do INS e da própria Border Patrol. Assim colocado, seria muito melhor dissuadir os "candidatos" a imigrantes ilegais, mantendo-os do outro lado da fronteira, do que ter de lidar com eles em território norte-americano.

Contudo, deve-se salientar que a maior consequência de tal estratégia, na prática, foi ter desviado os fluxos migratórios para áreas mais remotas e inóspitas, tais como desertos e

\footnotetext{
${ }^{58}$ Pesquisas conduzidas na região de El Paso (quase 75\% de hispânicos), em outubro de 1994, demonstraram que, paradoxalmente, quase $85 \%$ da população local apoiava a operação (DUNN, 2009: 67). O fato do patrulheirochefe ser descendente de mexicanos (seu avô deixou o México à época da Revolução Mexicana, tendo integrado as forças de Villa) e da Border Patrol ter parado de abordar ostensivamente os moradores de El Paso e se concentrado em outras atividades ("dissuasão") foram decisivos para tal. Em termos nacionais, a despeito de reforçar velhos estereótipos e preconceitos, a operação foi tão bem aceita que o governo Clinton a tomou como modelo para a sua política de segurança da fronteira, cuja ação mais "espetacular” foi a Operação Gatekeeper.
} 
montanhas, o que levou a um expressivo aumento no número de mortes de imigrantes que tentavam a travessia ${ }^{59}$.

O marco inicial das operações foi a denominada Operação Blockade (posteriormente renomeada Hold-the-Line, por conta de reclamações do governo mexicano), lançada em 19 de setembro de 1993 pela Border Patrol estacionada em El Paso. É bastante curioso o fato de que suas origens foram marcadamente locais: em meio a uma grave crise de confiança da população local na Border Patrol, fomentada por uma série de denúncias de violações de direitos humanos - as quais renderam um histórico processo judicial - o patrulheiro-chefe do INS para a área, Sylvestre Reyes, decidiu implementar a Operação, em boa medida, como uma resposta às críticas referentes aos abusos em matéria de direitos humanos e a sua própria percepção de "descontrole" da fronteira. Após cuidadoso planejamento, Reyes lançou a Operação do modo mais "espetacular" possível, alinhando um total de 400 agentes da Border Patrol nas margens do Rio Grande e adjacências na virada de sábado para domingo, mais uma série de veículos de patrulha estacionados a distâncias regulares uns dos outros (DUNN, 2009: 59-60). Além desta "muralha virtual", completavam o cenário alguns helicópteros de patrulha que voavam baixo ao longo da margem do rio. Desnecessário dizer que o impacto visual da operação foi avassalador. Mais midiático, impossível.

Com a fronteira urbana entre El Paso e Ciudad Juárez tomada pela Border Patrol, lá estacionada 24 horas por dia e em base permanente, o número de apreensões feitas caiu $80 \%$ nas primeiras semanas, tendo fechado o ano com uma queda média de $72 \%$ - um enorme sucesso, dado que o novo paradigma centrava-se na dissuasão e não na apreensão. Logo, um alto número de apreensões, que no passado indicaria um trabalho eficiente, doravante indicaria o fracasso da nova estratégia, baseada na dissuasão.

A alta cúpula do INS, que foi bastante reticente no início e via a proposta de Reyes com ceticismo, agora chamava para si a iniciativa, pegando carona no sucesso inesperado da Operação, que serviria de modelo para as operações subsequentes.

Outro ponto importante é que Reyes conseguiu convencer a opinião pública de El Paso que o motivo fundamental para o lançamento da Operação foi "barrar a criminalidade", garantindo a segurança da população, e não propriamente a questão da migração dos indocumentados. Como os índices de criminalidade de fato foram reduzidos logo nas

\footnotetext{
${ }^{59}$ Segundo Nevins (2010: 173), a despeito do fato de que o ingresso ilegal nos EUA sempre foi uma atividade potencialmente fatal, no início do governo Clinton - e das Operações - ocorreu um aumento dramático no número de mortes documentadas, passando de 350 óbitos/ano já a partir de 1995. A causa mortis, quase sempre, tinha relação com fatores ambientais (exposição a calor extremo; gerando exaustão, desidratação e desorientação, por exemplo).
} 
primeiras semanas, a população decidiu por apoiar a medida, dando-lhe a legitimidade necessária e reabilitando a imagem da Border Patrol.

O governo mexicano, por seu turno, ficou chocado com a Operação, ainda mais por conta do momento político: o NAFTA, após anos de negociações e promessas mútuas de cooperação, tramitava no Congresso dos EUA, aguardando a ratificação. Contudo, passadas algumas semanas, o governo mexicano declarou que os EUA tinham todo o direito de implementar a Operação - ainda que não concordasse com ela. O compromisso histórico do México com a ideia de soberania nacional e sua tradicional postura defensiva com relação aos EUA não os dava muitas opções para criticar a Operação (DUNN, 2009: 76).

Pouco tempo depois, no dia $1^{\circ}$ de outubro de 1994, o INS lança a Operação Gatekeeper em San Diego, a primeira medida concreta do governo Clinton com relação ao tema da imigração, que se tornava potencialmente explosivo em uma Califórnia imersa na recessão econômica e densamente habitada por "hispânicos" (mexicanos e americanomexicanos, em grande parte). Esta operação apoiava-se no novo plano estratégico da Border Patrol, de julho de 1994, cujo principal objetivo assim estava colocado: "The US Border Patrol will control the borders of the United States between the ports of entry, restoring our Nation's confidence in the integrity of the border. A well-managed border will enhance national security and safeguard our immigration heritage." (US Border Patrol, 1994 apud Nevins, 2010: 04). Ainda que a Border Patrol concordasse que selar por completo a fronteira era impossível, ela afirmava que era necessário - e factível - restaurar o controle sobre a fronteira.

Considerando que o binômio San Diego/Tijuana era o corredor migratório por excelência da fronteira, desde os dias em que sequer haviam controles migratórios, essa área era chave para a implementação da nova estratégia e, se alcançasse sucesso, poderia garantir a Clinton os votos necessários para a sua campanha de reeleição. Ora, uma região com os maiores índices migratórios (legais e ilegais) e maiores índices de apreensões e deportações pela Border Patrol (antes da nova estratégia), mergulhada em uma severa convulsão econômica, acabou por se tornar o pólo atrativo por excelência de políticos, grupos, ativistas e organizações restricionistas que, desfilando uma agressiva retórica anti-imigração e, mais ainda, anti "illegal aliens", conseguia se fazer ouvir por uma população cada vez mais desorientada e ansiosa.

Foi justamente neste contexto que a infame Proposition 187 foi lançada, debatida e aprovada, com larga maioria, pela população da Califórnia, em um claro sinal ao governo federal do clima político da região e da sensação geral de insegurança e insatisfação. Esta 
proposição, em síntese, estabelecia que a educação pública, os serviços públicos em geral e até os serviços públicos de saúde (com exceção dos casos de emergência médica) deveriam ser negados, pelo Estado da Califórnia, a todos os imigrantes indocumentados ${ }^{60}$.

Joseph Nevins (2010: 109) acrescenta que, no caso da Gatekeeper, a questão não estava centrada apenas nos "mexicanos indocumentados"; havia todo um cenário de medo, em escala nacional, construído a partir da ideia de que o país estava "sitiado" por "inimigos externos", sendo a região da fronteira o lado mais fraco da nação. Veja-se a somatória de fatos ocorridos em 1993: o atentado ao World Trade Center (supostamente cometido por imigrantes indocumentados); o assassinato de dois agentes da CIA por um imigrante indocumentado de origem paquistanesa; a descoberta do navio Golden Venture, na costa de Nova Iorque, com 286 imigrantes indocumentados de origem chinesa (dez deles morreram afogados tentando se evadir da Guarda Costeira); e uma poderosa retórica anti-imigração que, por conta dos fatos, voltava ao topo da política nacional, denunciando a "invasão" do país por "hordas de ilegais". Misture-se tudo isso no denso caldo da recessão econômica e o resultado só poderia ser um desastre anunciado. Não é à toa que a Proposition 187 foi aprovada com tanta euforia.

Diante de tal cenário, o governo Clinton lança a Operação Gatekeeper que, emulando a Operação Blockade - notadamente no quesito "espetáculo" - buscou fazer uma demonstração de força do longo da fronteira, alinhando centenas de agentes da Border Patrol (cujo efetivo ele havia dobrado) muito bem equipados em pontos estratégicos e assumindo uma disposição ostensivamente visível, complementados por veículos de patrulha e helicópteros. Além disso, reformou e ampliou as barreiras físicas existentes (cercas, muros, etc.), adicionou sistemas de iluminação mais poderosos, sensores de movimento infravermelho e toda uma parafernária eletrônica de vigilância, dando à Operação um caráter grandioso. Em termos midiáticos, a Operação foi um enorme sucesso, tendo gerado uma sensação de paz e tranquilidade na população local quase que imediata. Contudo, tal como na Operação Blockade, os fluxos de migrantes indocumentados acabaram sendo desviados para áreas pouco vigiadas, mais remotas, onde as chances de sucesso na travessia são parcas. $\mathrm{O}$ resultado, como não poderia deixar de ser, foi um expressivo aumento no número de mortes de indocumentados que, desesperadamente, buscavam uma vida minimamente digna do outro lado da fronteira.

\footnotetext{
${ }^{60}$ A percepção pública da "ameaça" representada pela migração ilegal era muito alta, sendo a narrativa da "ameaça latina" algo onipresente nos discursos e mentalidades dos californianos, à época, indicando um iminente retorno da crise migratória dos anos 1970 que, como já visto, disparou uma nova onda de militarização baseada na Doutrina do LIC. Joseph Nevis é enfático a esse respeito: "the perception of the illegal alien as a significant threat to the American social fabric emerged most strongly in California during the debate surrounding Proposition 187” (NEVINS, 2010: 143).
} 
$\mathrm{Na}$ precisa avaliação de Joseph Nevins (2010: 113-114), pode-se compreender a Operação Gatekeeper, em boa medida, como uma resposta à Proposition 187 e, quiçá, uma tentativa de derrotá-la. Se o governo Clinton conseguisse demonstrar que estava cuidando do "problema da fronteira" de um modo eficiente, ele poderia esperar que o eleitorado californiano sentisse uma menor necessidade de aprovar (e implementar) a Proposition. Indo mais além, a Operação também pode ser vista como um esforço dos Democratas no sentido de tomar a dianteira na alegada "batalha" contra a imigração ilegal antes das eleições de novembro de 1994. Por último, é bastante evidente que a Operação foi, também, um "espetáculo" político, cuidadosamente elaborado para consumo público de tal sorte a demonstrar a seriedade do governo Clinton com relação ao cada vez mais candente tema da imigração ilegal. Os claros esforços da Casa Branca e do INS para maximizar a cobertura da mídia sobre a Operação não deixam dúvidas com relação a isso. Dessa forma, a fronteira Estados Unidos-México foi transformada em um portentoso palco, cuja plateia atingiu proporções nacionais. Contudo, duas coisas não podem ser esquecidas: i) a Operação representou mais uma tentativa de se impor um rígido controle estatal em uma faixa determinada da fronteira - aliás, aos poucos a Operação foi se estendendo à leste, chegando a cobrir toda a fronteira sul da Califórnia - e ii) ela foi a cristalização de um longo processo histórico de significação, construção identitária e segregação apoiado em uma estratégia de progressiva militarização.

Em 1995, a Operação Safeguard é lançada no Arizona (Nogales), nos mesmos moldes da Gatekeeper, tendo sido expandida para Douglas e Naco em 1999. Ainda em 1995, o Congresso aprova o Antiterrorism and Effective Death Penalty Act (AEDPA) e o Illegal Immigration Reform and Immigrant Responsibility Act (IIRIRA) os quais, em conjunto, levaram a um gigantesco aumento no número de deportações de imigrantes que estavam em situação absolutamente legal, o que demonstra o nível de histeria existente contra os imigrantes - mexicanos e centro-americanos, em sua vasta maioria ${ }^{61}$. Por fim, neste mesmo ano, o INS lança a Operação Rio Grande, em Brownsville (Texas), que representou o último grande esforço da Border Patrol centrado na estratégia da "prevention through deterrence". Doravante, com os principais pontos de entrada sob controle (e os fluxos desviados para áreas mais remotas e extremamente perigosas), a Border Patrol seguiria agindo, mas em escala local e sem "espetáculos".

\footnotetext{
${ }^{61}$ Ariane C. d'Appollonia (2012: 54) esclarece que estas legislações fizeram o linkage, em termos legais, entre o terrorismo e a imigração ilegal. O AEDPA, por exemplo, expandiu a tipologia de crimes graves, determinando que os "non-citizens" ficassem sujeitos - retroativamente! - a detenção e deportação obrigatórias, sem que sequer fossem consideradas eventuais circunstâncias atenuantes.
} 
$\mathrm{Na}$ extremamente feliz avaliação de Peter Andreas (ANDREAS, 2009: 100), essa escalada nos esforços de controlar a imigração ilegal na fronteira, nos anos 1990, foi altamente seletiva, haja vista que - o que é pouco divulgado - aproximadamente $50 \%$ de todos os ilegais nos Estados Unidos entraram no país legalmente, com visto de turista ou de estudante, lá permanecendo após o prazo legal do visto ter expirado. Um outro ponto crucial a ser ressaltado é que, enquanto todas as atenções se concentravam na fronteira, praticamente nada foi feito com relação aos empregadores que contratam mão de obra ilegal; nem mais sanções, nem maior efetividade destas, nem padrões mínimos de conduta. Daí a conclusão do pouco divulgado Relatório do US Comission on Immigration Reform de que "by one measure, Operation Gatekeeper appears to have had little effect - the availability of workers in industries that are dependent on illegal alien labor" (US Comission on Immigration Reform, 1995: 07 apud ANDREAS: 2009, 100).

Encerrando, pode-se afirmar que este ciclo de operações especiais constituiu-se em uma espécie de "segunda onda de securitização", mais militarizada e midiática que a anterior e que, por ter desviado os fluxos de migrantes ilegais para áreas mais remotas, hostis e extremamente perigosas, contribuiu em larga escala para o aumento das mortes de imigrantes durante a penosa travessia. Outro ponto a destacar foi o aumento expressivo no uso de equipamentos eletrônicos de última geração, destinados a reforçar as capacidades de controle e vigilância da Border Patrol, além da institucionalização de práticas (notadamente, a militarização) que, não raro, remontam aos primeiros dias da fronteira, tornando indisfarçável o caráter ostensivamente segregacionista e racista das práticas, estratégias e políticas adotadas, todas destinadas a conter, em síntese, as "hordas hispânicas", mantendo-as do outro lado da fronteira, de modo a preservar a identidade nacional norte-americana tomada por homogênea e cercada pela mítica da pureza. Que os "bárbaros", portando, continuem do outro lado da fronteira - cada vez mais fisicamente "fortificada" por cercas, muros e sistemas eletrônicos de vigilância e controle. 


\section{CAPÍTULO IV - A Escalada da Securitização e suas Consequências}

"Another problem introduced by the United
States is the plan to build a fence (...) as an
anti-immigration, antidrug device. The
fence building has also become an
antiterrorist measure. If the US argument is
based on the fence having so many
objectives, it is probably because there is
nothing solid to any single purpoted
motive"

(WEINTRAUB, 2010: 126)

\subsection{Civilização vs. Barbárie: de volta ao início}

Os trágicos eventos do Onze de Setembro de 2001 marcaram, na opinião do geógrafo Jason Ackleson (2005: 175), professor da Universidade do Estado do Novo México, o fim da era do pós-Guerra Fria, gerando uma avalanche de debates e estudos sobre o significado deste lamentável evento e suas implicações para diversas áreas de estudo, direta ou indiretamente ligadas ao tema do terrorismo.

Debates acadêmicos à parte, é certo que uma das mais claras respostas do governo dos EUA à nova situação foi a dirigida às suas fronteiras e a sua política imigratória. Ainda que tanto as políticas de segurança quanto os discursos que as sustentam possam ter suas origens nos anos 1970, marcados pela Doutrina do LIC, e a questão da segurança de Estado ter sido fundida à da segurança societal bem antes dos ataques, tornando-se o discurso dominante deste então no trato das fronteiras, no imediato pós-Onze de Setembro houve uma escalada na securitização sem precedentes na história dos EUA. O fato da questão migratória ter saído da esfera do INS (que foi dissolvido em 2003) e passado para o recém-criado Departamento de Segurança Interna (Department of Homeland Security) ${ }^{62}$ representa a consolidação; o ápide da securitização das migrações em um nível nunca antes atingido, dando início a "terceira onda de securitização", por assim dizer.

É curioso ressaltar que os terroristas que perpetraram os ataques entraram legalmente no país, com vistos de estudante, ainda que alguns deles tenham se valido de passaportes falsos. De qualquer modo, eles não atravessaram a fronteira Estados Unidos-México

\footnotetext{
${ }^{62}$ Em 2003 é criado o Department of Homeland Security (DHS), que absorveu o INS (agora extinto), o Customs Service, a Guarda Costeira e outras agências, sendo que as funções do antigo INS foram divididas em três novas agências, subordinadas ao DHS: a US Immigration and Customs Enforcement (ICE), a US Customs and Border Protection (CBP) e o US Bureau of Citizenship and Immigration Services (CIS).
} 
ilegalmente; tampouco a Estados Unidos-Canadá ${ }^{63}$; não eram mexicanos nem "latinos". Mas, a despeito do novo inimigo ter sido classificado como "árabe-muçulmano", colocando em um mesmo patamar todas as pessoas nascidas no Oriente Médio e todos aqueles que professam a religião muçulmana, doravante tratados simplesmente como "terroristas" pelo novo discurso histérico-paranoico dominante, seriam os mexicanos "indocumentados", novamente, os mais afetados pelas novas medidas e políticas de segurança para a fronteira. Afinal de contas, à eles sempre foi imposto o papel de "inimigo conveniente", o bode expiatório ideal para vários problemas enfrentados pelos EUA - muitos dos quais, vale dizer, criados pelo próprio governo dos Estados Unidos.

É bastante correta a análise de Ackleson (2005: 177) quanto ao fato de que foi uma "violência não-discursiva" (os ataques terroristas) que alterou as percepções de ameaça e a formatou as novas políticas. Contudo, "some of the altered political agenda can also cleary be traced in the discourse on the new threat of terrorism and the somewhat changed perception of migrants and US borders in several political narratives". De algum modo - ao menos no início - a imagem daqueles que "odeiam a América" e querem "infligir destruição" a seus habitantes foi deslocada dos trabalhadores mexicanos que perseguem o Sonho Americano para os "terroristas", tal como acima perfilados. A fronteira Estados UnidosMéxico passou, portanto, a ser vista como um corredor para a entrada de terroristas em solo americano, a despeito de: i) nunca ter existido uma evidência sequer de que algum terrorista tenha tentado ingressar nos EUA pela fronteira, e muito menos como "indocumentado" afinal, o mercado de documentos falsos é muito bem estruturado, e aa falsificações atingem um requinte e sofisticação cada vez maiores; e ii) nunca ter sido feita uma avaliação realista acerca das possibilidades de selamento da fronteira, tornando-a "inexpugnável”, como querem, do alto de sua inocência (ou hipocrisia), muitos políticos e formadores de opinião nos EUA.

A teoria de securitização ajuda a entender como a "ameaça terrorista" advinda da fronteira Estados Unidos-México foi, em grande parte, uma construção discursiva. Jason Ackleson (2005) aponta alguns casos típicos de speech act, todos proferidos pelo alto escalão do governo dos EUA:

Attorney General John Ashcroft: "The menace of terrorism knows no borders, political or geographic" (2002);

\footnotetext{
${ }^{63}$ Peter Andreas (2009: 159) afirma, com boa dose de ironia, que a fronteira Estados Unidos-Canadá passou por um processo de "mexicanização" - ainda que parcial - após os ataques do Onze de Setembro.
} 
The Congressional Immigration Reform Caucus: The time is right to call for troops on the border in order to protect our national security interests" (2002);

Representative Tom Tancredo (R-Colorado): "The defense of the nation begins with the defense of its borders" (2001); We can't protect ourselves from terrorism without dealing with illegal immigration (...) To reduce the likelihood of future attacks, Congress has a responsability to take concrete action to ensure immigration laws are enforced" (2002);

Representative J. D. Hayworth (R-Arizona): "In this trying times border security is synonymous with national security" (2004);

The US State Department: We are faced with a more diffuse and insidious threat... by our open borders" (2001);

The Department of Homeland Security: Heightened security at our land border crossings has provided a strong defense against terrorists seeking entry into the US through our ports of entry" (2002).

Fica bastante evidente que, considerando o tom dos discursos, que "combater o terrorismo" ao longo das fronteiras tornou-se um objetivo de segurança nacional e a perfeita justificativa para a expansão das políticas de segurança adotadas nos anos 1990 para a região da fronteira sul que tinham como alvo prioritário os imigrantes indocumentados e o tráfico internacional de drogas. Doravante, o terrorismo tornaria-se o terceiro alvo, assumindo o topo das prioridades. Contudo, as mesmas políticas e medidas que, em tese, buscam eliminar a ameaça terrorista também acabam "eliminando", por assim dizer, os indocumentados, vitimados pelos "danos colaterais" das medidas implementadas, notadamente, por forças militares, que passam a atuar tanto interna quanto externamente na chamada "guerra contra o terror".

Aliás, esta "guerra", declarada pelo presidente George W. Bush no Congresso dos EUA $^{64}$, a 20 de setembro de 2001, ao reclassificar o terrorismo de crime para uma nova modalidade de guerra, fez com que as atividades de contraterrorismo não fossem mais uma luta contra criminosos, mas sim uma guerra contra tudo e todos que, de alguma forma, estivessem envolvidos com os ataques. Nos dois lados do Atlântico, esclarece Ariane d'Appolonia (2012: 49-50), professora e pesquisadora da Rutgers-Newark e da Sciences Po, os eventos do Onze de Setembro foram descritos como "excepcionais" e "sem precedentes", conectando com a imagem popular de "insegurança global" que foi sendo rapidamente construída após os ataques. Desta feita, as novas e excepcionais ameaças requeriam, para a sua devida neutralização, "medidas excepcionais", o que implica, em última análise, na

\footnotetext{
${ }^{64}$ Ele afirmou, literalmente: "We are a nation at war".
} 
securitização da questão do terror e das migrações, uma vez que os dezenove sequestradores do Onze de Setembro eram todos imigrantes - um dado fundamental para o endurecimento das políticas migratórias, desenhadas e legitimadas (pelos discursos) como medidas apropriadas e eficientes para conter o avanço do terrorismo.

Mais ainda, este discurso histérico-paranoico levou o Congresso norte-americano, pouco mais de um mês após os ataques, a aprovar o Patriot Act (2001) que, além de restringir uma série de liberdades e direitos civis historicamente constituídos e aumentar o poder legal do governo em matéria de vigilância e espionagem (inclusive de seus próprios cidadãos), autorizou que o número de agentes da Border Patrol e do INS fosse triplicado ao longo da fronteira Estados Unidos-Canadá que, historicamente, sempre foi parcamente vigiada, se comparada com a fronteira sul dos EUA. O Patriot Act, em síntese, foi a pedra de toque que deu início a um "estado de exceção" 65 que foi tornado permanente, ou seja, em tese, ficará em vigor até que a "guerra contra o terror" atinja o seu fim. Como isso é fantasioso, o futuro das liberdades civis nos Estados Unidos é bastante incerto.

Ariane d'Appolonia (2012: xi) desenvolve uma interessante tese acerca do que denomina "nexo terrorismo-imigração". Na sua análise, o nexo é definido como a implementação de medidas e políticas migratórias restritivas que se destinam a combater o terrorismo, ao mesmo tempo em que o contraterrorismo é utilizado de modo a gerenciar os fluxos migratórios e controlar minorias.

Na sua avaliação (2012: 77-81), este nexo foi consolidado de um modo bastante sólido por conta dos eventos do Onze de Setembro. Em primeiro lugar, a crença generalizada de que os estrangeiros teriam uma maior inclinação do que os "cidadãos" para o cometimento de ataques terroristas foi mais que suficiente para justificar uma abordagem no estilo "tolerância zero" referente a ilícitos de ordem migratória; a um controle mais duro e incisivo das fronteiras; e, até mesmo, no caso da União Europeia, a uma abordagem extraterritorial de controles de fronteira e práticas conexas. As noções vagas e marcadamente imprecisas adotadas para definir "imigrante" e "terrorista", fundadas em análises de risco altamente duvidosas, ajudaram a criar a imagem de um Estados Unidos (e de uma União Europeia) sujeitos à infiltração de terroristas, por vias legais ou ilegais, determinados a praticar seus atos típicos. Logo, todos os imigrantes passaram a ser vistos como "terroristas em potencial", legitimando práticas e políticas não apenas restritivas mas extralegais.

\footnotetext{
${ }^{65}$ Este assunto será tratado separadamente, no subitem 4.1.2.
} 
Em segundo lugar, a propositalmente imprecisa e vaga noção de "guerra ao terror" sugere que o escopo dos esforços e políticas de contraterrorismo dos EUA pode muito bem ser alargado indefinidamente, de modo a que se possa responder à natureza eminentemente global da nova ameaça. Com o apoio de toda uma nova legislação de caráter francamente "extraordinário", o governo dos EUA pode ver seus poderes alargados, incluindo os das agências de segurança e de law enforcement, liberados "momentaneamente" de restrições de caráter legal.

Três dimensões da "guerra ao terror" estão intimamente ligadas ao nexo terrorismoimigração, a saber: i) medidas de segurança destinadas à proteção interna (homeland security); ii) ações extraterritoriais, tais como a intervenções no Iraque e no Afeganistão; e iii) medidas destinadas diretamente aos imigrantes; em especial, os de determinadas nacionalidades e os pertencentes a determinadas categorias (os indocumentados e os em busca de asilo/refúgio).

No caso da Segurança Interna, o Patriot Act, para além do que já foi visto, também expandiu a definição legal de "terrorismo", de modo a abarcar uma série de situações e condutas que não eram previstas anteriormente. Na prática, a intenção foi a de que, sempre que necessário, a tarja de terrorista possa ser aplicada a qualquer caso que afete a "segurança nacional”. Ele também aumentou os poderes do Departamento de Justiça, liberando-o de antigas amarras legais com o intuito de facilitar a condução das suas atividades no que concerne ao combate ao terror, implicando na evidente restrição dos direitos e liberdades civis dos próprios cidadãos norte-americanos, sem contar os efeitos sobre os “indocumentados" em geral. Desta forma, escutas telefônicas sem autorização legal podem ser feitas sempre que houver "suspeita de atividade terrorista"; o mesmo com o caso dos e-mails e das atividades na internet. No caso de "aliens" suspeitos de atividade terrorista (cuja definição, além de vaga, é extremamente imprecisa), estes podem ficar detidos por até sete dias, após o qual devem ser indiciados, deportados ou - se for o caso - simplesmente liberados. Caso o Attorney General considere que a liberação do sujeito pode colocar em risco a "segurança nacional", ele tem poder para autorizar a sua detenção por um período indeterminado. Nota-se, portanto, a degradação das liberdades civis em um país que sempre se orgulhou de defendê-las.

Através da Homeland Security Presidential Directive 2 (2001), emitida pelo governo Bush com o intuito de combater o terrorismo através das políticas migratórias, ficou estabelecido que "it is the policy of the United States to work agressively to prevent aliens who engage in or suport terrorist activity from entering the United States and to detain, prosecute, or deport any such aliens who are within the United States". 
Já o Real ID Act, aprovado em 2005 pelo Congresso dos EUA, concedeu ao secretário de Segurança Interna a autoridade legal para afastar quaisquer leis de modo a garantir a presteza necessária para a construção de infraestrutura, barreiras e afins ao longo da fronteira, além de ter ampliado a aplicação do termo "engage in terrorist activity" de modo a alargar, ainda mais, a sua aplicabilidade prática.

Por fim, o Protect America Act, de 2007, autorizou a coleta e armazenamento massivo de comunicações nacionais e internacionais sem que, para tanto, seja necessária uma ordem judicial específica, permitindo que o governo dos EUA decida como coletar, armazenar e utilizar os informações coletadas. O sigilo das comunicações foi quebrado, de um modo absoluto e por tempo ilimitado, por conta da necessidade imperiosa de "conter o terrorismo" e salvaguardar a "segurança nacional"; afinal, "tempos extraordinários requerem medidas extraordinárias".

Com relação às medidas destinadas diretamente aos imigrantes; especialmente os indocumentados, aqueles em busca de asilo ou refúgio ou os pertencentes a certas nacionalidades (consideradas "suspeitas"), a autora (2012: 93-94) destaca que, além do alargamento das bases do Immigration and Nationality Act (INA), datado de 1952, de modo a alcançar toda a sorte de atividades direta ou indiretamente ligadas ao terrorismo, permitindo procedimentos de deportação mais rápidos e negativa de entrada sem justificativa adicional, houve também uma mudança no "espírito" das políticas migratórias que, doravante, seguem uma agenda criminal, afetando tanto imigrantes legais quanto os "ilegais". A Suprema Corte, por seu turno, já declarou que os "não-cidadãos" norte-americanos, independentemente de seu status legal, contam com uma menor proteção constitucional apesar do disposto em algumas Emendas (particularmente, a Primeira, a Quarta, a Quinta e a Décima-Quarta Emenda Constitucional). O Patriot Act também restringiu os direitos civis dos "não-cidadãos". Com isso, qualquer imigrante indocumentado, tal como os indivíduos encarcerados pelo sistema criminal dos EUA, passaram a ter negado o acesso a um número cada vez maior de direitos e benefícios sociais; também podem ser detidos por tempo prolongado, em instalações originariamente destinadas a receber apenas criminosos condenados pela Justiça; e as possibilidades legais para a deportação aumentaram em grau exponencial, de modo que, na prática, qualquer conduta que seja "interpretada" como relacionada a alguma atividade terrorista torna o seu praticante passível de deportação, e sem maiores explicações.

A “Joia da Coroa", por assim dizer, está na autorização - sem precedentes históricos dada pelo governo americano para a condução de "procedimentos secretos" (sigilosos para o público, a imprensa e a família do acusado), bem como para o uso de "secret evidence" para 
deter e deportar imigrantes, independentemente de seu prévio status legal. O Departamento de Justiça, destaca a autora, se recusa a divulgar as mais elementares informações sobre, por exemplo, o número de detidos e o tempo médio de detenção.

Cobertos pelo Patriot Act, os serviços de imigração podem manter um estrangeiro detido, ainda que um juiz tenha ordenado sua soltura, simplesmente apelando contra tal ordem. Em alguns casos, os detidos sequer tem a possibilidade de se defenderem legalmente, dado que podem ficar detidos, preventiva e indefinidamente, sem uma audiência sequer, apenas por serem considerados "suspeitos" de alguma atividade terrorista.

O debate sobre a política migratória de 2005-2006, como não poderia deixar de ser, esteve firmemente ancorado em preocupações de segurança. O presidente Bush propôs a criação de um guest work program, muito similar ao Programa Bracero, por sinal, enfatizando a necessidade de uma maior fiscalização sobre os contratantes, e também em reforço em termos de pessoal e equipamentos para a guarda e vigilância da fronteira sul. Em maio de 2006 a Casa Branca reiterou seu apoio a uma ampla reforma migratória, ao mesmo tempo em que alocou, em base permanente, seiscentos militares da Guarda Nacional para o patrulhamento da fronteira com o México. Curiosa a declaração de Bush nesse sentido (apud d'Appollonia, 2012, 94):

(...) first, the United Stated must secure its borders. This is a basic responsibility of a sovereign nation. It is also an urgent requirement of our national security. Our objetive is straightfoward: The border should be open to trade and lawful immigration and shut to illegal immigrants, as well as criminals, drug dealers and terrorists.

Como se fosse simples, ou, melhor, como se a securitização fosse a ferramenta ideal e efetiva - para tanto. Na verdade, a securitização das migrações, notadamente na fronteira dos Estados Unidos-México, já se provou altamente custosa (tanto em termos econômicos quanto humanos), contra produtiva, ineficiente e extremamente prejudicial tanto para os imigrantes quanto para as políticas migratórias, gerando, ao final, mais insegurança (d'Appollonia: 2012, xi).

Apesar dos apelos para um novo guest work program, sempre associado a mais segurança fronteiriça, o que a Câmara decidiu foi focar apenas na questão do controle da fronteira e, em 2005, aprovou o denominado Border Protection, Antiterrorism, and Illegal Immigration Act, colocando em uma mesma legislação disposições referentes a imigração ilegal e ao terrorismo, associados a mais medidas destinadas a reforçar a segurança da fronteira contra estes dois “inimigos"; por vezes, tomados como um só. Mais de 2.2 bilhões 
de dólares para a construção e ampliação das cercas, muros e afins ao longo de grandes trechos da fronteira sul; mais equipamentos de vigilância e controle, tais como câmeras com visão noturna e sensores de movimento e de calor, sempre de última geração; mais restrições legais e de direitos constituídos - como curiosidade, sob esta lei o ato de auxiliar um indocumentado a permanecer nos EUA foi tipificado como crime. Felizmente, dada a mobilização contrária que provocou por parte de uma ampla rede de organizações; da $U S$ Chamber of Commerce a ONGs de caráter humanitário, associada a protestos populares em cidades como Nova Iorque, Los Angeles e Chicago, totalizando mais de um milhão de pessoas nas ruas, pelo país todo, o Senado a rejeitou (d'Appollonia: 2012, 95).

Porém, em seu lugar veio o Secure Fence Act (2006), que ordenou a construção de 850 milhas adicionais (nota: algo próximo a $1.400 \mathrm{~km}$ ) de, no mínimo, duas camadas de "cerca reforçada", em determinados trechos da fronteira Estados Unidos-México, além de estradas para o patrulhamento entre as duas "camadas". Ela também dobrou o orçamento para a segurança da fronteira, deslocou milhares de membros da Guarda Nacional para a fronteira sul, de modo a que pudessem cooperar com as atividades da Border Patrol ${ }^{66}$, além de aumentar o número de vagas, no sistema penitenciário, para futuros indocumentados que, por ventura, viessem a ser “detidos”. Neste mesmo ano, sob a coordenação do DHS, teve início o projeto SBInet, um programa multibilionário, a ser desenvolvido por vários anos ${ }^{67}$ com o objetivo de transformar por completo a infraestrutura e a tecnologia de controle da fronteira. A ideia é empregar o que há de mais avançado e efetivo em matéria de tecnologia, infraestrutura e treinamento de pessoal de modo a que tudo funcione de um modo integrado e permita uma resposta rápida a qualquer tipo de problema (ou ameaça) nas fronteiras sul e norte dos EUA.

Na sequência de inúmeros projetos de lei apresentados e debatidos no Congresso com vistas a seguir reformando a política migratória, merece destaque o fato de que, em 2007, o presidente Bush comandou uma nova (e última) rodada de negociações com os partidos, o que levou ao projeto denominado Secure Borders, Economic Opportunity, and Immigration Reform $A c t^{68}$. Este projeto de lei buscava ser uma espécie de "meio-termo", uma solução de compromisso entre as diversas forças presentes no Congresso e o Executivo dos EUA. Assim, ao mesmo tempo em que previa um determinado procedimento para que os indocumentados pudessem obter a cidadania norte-americana, ela também não descuidava da segurança a

\footnotetext{
${ }^{66}$ Vale destacar que, em 2009, a Border Patrol atinge um contingente total de 20.000 agentes.

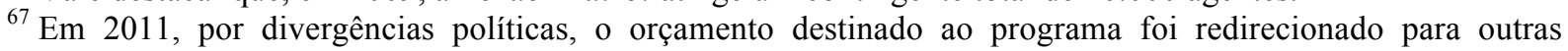
iniciativas de controle e vigilância da fronteira, ficando o programa paralisado desde então.

${ }^{68}$ Também conhecido como Comprehensive Immigration Reform Act.
} 
fronteira: mais fundos, mais cercas, mais equipamentos, etc. Em suma, mais do mesmo, em uma interminável espiral de progressiva militarização e fechamento da fronteira. O projeto foi apresentado ao Senado a 9 de maio de 2007, mas nunca foi votado (d'Appollonia: 2012, 98).

O fracasso da reforma da política migratória dos EUA possui muitas causas, dentre elas, as complexidades inerentes ao processo legislativo e as sempre presentes considerações de caráter eleitoral. Criticada por ambos os lados (pró e contra imigração) a "solução de compromisso" adotada, ao final, acabou por rechaçada por todas as partes envolvidas; de partidários do livre comércio e da liberdade de mão de obra até os radicais defensores do fechamento total da fronteira com o México. Outro fator que pesou contra foi a questão da segurança. O presidente Bush contribuiu muito com isso, sinalizando ora para os defensores de maiores controles, ora para os partidários de uma abordagem mais integrada e humana. Com um discurso dúbio e inconsistente, ao invés de angariar apoio para sua proposta, ele conseguiu que ela fosse rejeitada por ambos os lados. Como pano de fundo, haviam as pesquisas que indicavam sua perda de popularidade, as controvérsias geradas por conta da Guerra no Iraque e a contínua erosão na sua base de apoio no Congresso, com os Republicanos se afastando cada vez mais dele e de suas propostas. Não poderia ser mais claro o congressista Ric Keller (R-California): "There is not a lot of credibility right now with the administration on securing the border and enforcing the law" (entrevista ao Washington Post, junho de 2007 apud d'Appollonia: 2012, 99).

Como tentativa de resposta ao revés no Congresso, o governo Bush apresentou, em agosto de 2007, revelou uma série de medidas destinadas a endurecer o controle da fronteira sul e a punir aqueles empresários norte-americanos que contratassem imigrantes indocumentados. Assim, seu novo plano trazia apenas medidas restritivas, sem uma menção sequer a guest workers e legalização. Contudo, às vésperas de Bush deixar a Casa Branca, já havia uma ideia geral, relativamente consolidada, de que a segurança da fronteira e a devida integração dos imigrantes à sociedade eram dois assuntos apartados, ainda que se interrelacionassem. O Senador McCain, um dos maiores apoiadores de uma reforma migratória bastante extensiva, declarou que o sistema atual estava falido, bem como a política migratória corrente. Contudo, os EUA deveriam, primeiro, resolver o problema da fronteira (d'Appollonia: 2012, 100). De outra sorte, haviam os proponentes de uma reforma migratória extensiva mas que não se relacionasse com a questão da segurança da fronteira. E o debate sobre a política migratória dos EUA, bem como sua mais que necessária reforma (defendida pelos dois lados), prosseguiu com o governo Obama sem que, até o momento, algum resultado concreto tenha sido atingido. 


\subsubsection{Nativismo e vigilantismo no ocaso da Razão}

Ainda que ambos fenômenos nada tenham de recentes; ao contrário, sejam bastante antigos - o nativismo, na América, pode ser localizado no seio das controvérsias geradas pela aprovação dos Alien and Sedition Acts, em 1798, momento no qual os franceses "étnicos" foram classificados como "inimigos", enquanto que o chamado vigilantismo deu os seus primeiros passos logo após o estabelecimento da fronteira com o México, nos tempos atuais eles ganharam um novo impulso - particularmente, na região da fronteira Estados UnidosMéxico. Seja por conta do trauma causado pelo Onze de Setembro, seja como uma espécie de “efeito colateral" do alto nível que o processo de securitização alcançou na região da fronteira, constituindo-se em uma verdadeira escalada e tendo como alvo prioritário os imigrantes indocumentados de origem mexicana (que são a grande maioria), o fato é que os dois fenômenos, combinados, tem sido uma fonte inesgotável de conflito, violência, intolerância e racismo ao longo da fronteira, contribuindo para desestabilizar as relações sociais, segregando pessoas e comunidades inteiras, além de darem causa a um sem-número de violações aos direitos humanos - quando não crimes, pura e simplesmente, contra os "inimigos" do momento.

Na avaliação de Joe R. Feargin (1997: 13-14), professor da Universidade da Flórida, o nativismo nos EUA de hoje pode ser sintetizado em um desejo, compartilhado por muitos norte-americanos, de restringir, excluir ou mesmo atacar imigrantes, seja pela forma verbal, pelo lobby para a aprovação de legislações cada vez mais restritivas; seja por atos de vandalismo e, no limite, de assassinato.

$\mathrm{Na}$ base ideológica do nativismo em geral e, por conseguinte, da sua versão norteamericana, podem ser encontrados vários elementos comuns e abertamente espúrios, a saber: i) certas "raças", por serem cultural e intelectualmente "inferiores" não deveriam ter autorização para entrar e estabelecer residência no país; aos menos, não em grande escala; ii) tais "raças", cada vez mais, ou não conseguem (por conta da inferioridade) ou não querem ser assimiladas pela cultura anglo-saxônica dominante; iii) estes imigrantes, independentemente de seu status legal, tem como objetivo "roubar" os empregos dos verdadeiros norte-americanos ("brancos") - tal discurso costuma ser comum em tempos de crise econômica - e; iv) estes imigrantes dão ensejo a sérias crises governamentais, sobrecarregando o sistema de ensino público, por exemplo, ou o sistema de welfare, drenando os recursos pagos com sacrifício pelo contribuinte norte-americano ("branco") sem nada oferecer em troca para a sociedade ou o Estado. 
De novidade, tais "argumentos", se é que se pode se referir a eles assim, nada tem. São os mesmos utilizados nos séculos XVIII e XIX. E seus perversos efeitos já foram bem documentados ao longo da história. O nativismo racista, por exemplo, começou a tomar forma por volta dos anos 1840-1850 na América, quando a ideia da superioridade anglo-saxônica atingiu igualmente brancos (não-anglo saxônicos) e negros. Contudo, com a emergência da ideia de "raça branca" enquanto um grupo social específico e nem definido, nos séculos XVIII e XIX, as vítimas do racismo nativista passaram a ser praticamente as mesmas por um longo período: os nativo-americanos ("índios"), os mexicanos e os negros; todos "selvagens incivilizados". Após a Guerra Civil (1861-1865), as elites políticas e econômicas dominantes se tornaram os maiores guardiões do nativismo racista (FEARGIN, 1997: 19-22).

Já o nativismo dirigido especificamente aos imigrantes começou a tomar forma nos idos de 1920, a partir dos movimentos migratórios em larga escala de várias "etnias", das asiáticas às europeias (sul e leste europeu, em particular). Toda a agitação anti-imigração acabou gerando, dentre outras coisas, legislações restritivas, cotas e toda a sorte de dificuldades para o estabelecimento, nos EUA, das novas levas de imigrantes - incluindo os mexicanos que, até o presente momento, não enfrentavam maiores dificuldades. Aliás, a fronteira sequer existia, na prática; era mais um "traçado na areia", nos termos de St. John (2013), do que outra coisa. Contudo, a partir de 1924 os controles começaram a ser estabelecidos, e as diferenças bem assentadas pelos processos de significação e identificação.

Por fim, o moderno nativismo, que tem suas origens nos anos 1980 a partir da percepção cada vez mais aguda de que os "latinos" são um problema real (é a narrativa da “ameaça latina" em ação), tem como estratégia uma abordagem diversificada, dada a enorme diversidade que existe entre os seus adeptos: vai desde o cometimento de crimes contra imigrantes de origem latina (mexicanos, em sua ampla maioria) até a apresentação de projetos de lei, no Congresso, visando a constituição de políticas e medidas cada vez mais restritivas, com vistas a enfrentar, no nível sistêmico, a alegada "ameaça latina" e todas as suas consequências (bilingualismo, separatismo, fim da "América”, etc.).

No caso específico da região da fronteira Estados Unidos-México, o nativismo assume a sua forma mais cruenta, posto que invariavelmente está associado a movimentos vigilantes, de viés paramilitar, cujas temerárias ações (para dizer o mínimo), ao invés de serem combatidas pelo Estado, são apoiadas por ele.

Na opinião de Néstor P. Rodriguez (1997: 223), professor da Universidade de Houston, as fronteiras políticas dos Estados-nação são construções sociais, e é assim que devem ser pensadas e analisadas. Por volta dos séculos XVIII e XIX, tais fronteiras atingiram o seu ápice 
em termos de consolidação; o nacionalismo, o nativismo e as preocupações concernentes à segurança nacional formaram as bases para o seu desenvolvimento e amadurecimento.

Uma vez consolidadas as fronteiras políticas, indivíduos, grupos e comunidades passaram a tentar cruzar tais fronteiras ainda que sem a devida autorização legal, seja para escapar de perseguições políticas, para buscar melhores condições de trabalho, ou ainda para se reunirem com seus familiares. E aí surge a problemática das migrações ilegais, a figura do “alien”, perseguido e odiado pelos nativistas, e toda uma série de políticas, muitas vezes contraditórias, no intuito de equacionar a questão posta.

Aliás, esta equação é praticamente um enigma, uma vez que a dinâmica das fronteiras é afetada por duas grandes forças opostas: enquanto o capitalismo força a abertura gradual (e permanente, de preferência) das fronteiras, de modo a maximizar o elemento trabalho e gerar o maior lucro ao menor custo, por todo o planeta, o Estado-nação, por conta do imperativo da segurança nacional, busca estabelecer um firme controle sobre as suas fronteiras, regulando os fluxos e decidindo, em última instância, quem tem autorização para atravessar a fronteira e quem não tem; quem e o que constitui uma ameaça à segurança nacional e, portanto, deve ficar do outro lado da fronteira, e quem e o que não constitui ameaça alguma, podendo adentrar ao seu território. No caso dos EUA, é patente o choque entre duas retóricas: a próNAFTA, que defende o seu aprofundamento e, por conseguinte, a liberação dos fluxos de mão de obra, e a pró-segurança, cuja versão mais radical defende o fim do NAFTA e o fechamento da fronteira com o México. No meio do fogo cruzado, o governo, que não tem tido sucesso, historicamente, no sentido de implementar uma política migratória que agrade a "gregos e troianos", por assim dizer. Aliás, sequer consegue implementar uma política de segurança para a fronteira coerente e funcional; que dirá equacionar a questão migratória.

No caso da construção social da sua fronteira sul, os EUA, durante todo o século XX, teve de lidar com uma série de grupos e atores (políticos, grupos restricionistas, personalidades midiáticas, acadêmicos, nativistas, etc.) que, ao criarem "conhecimento" acerca da realidade da fronteira, desfilaram os tradicionais argumentos de que esta estava fora de controle, que os massivos fluxos migratórios - notadamente dos indocumentados estavam destruindo as instituições, o welfare e até a identidade nacional dos EUA. Aos nativistas coube o papel de "tropa de choque", assumindo a liderança na luta pela retomada do controle da fronteira e pela preservação da identidade nacional norte-americana. Embalados por um nacionalismo atávico e pela percepção de ameaça derivada de uma fronteira desgovernada, estes grupos lideraram a construção dos discursos e das práticas destinadas a salvaguardar a América. Nas palavras de Rodriguez (1997: 227): 
National security is seen as essencial for national sovereignty and the public order, hence the governments have the right to control the entry of people from other countries. According to this perspective, unrestrained entry through the US southern border endangers the existence of basic social, cultural, and political institutions, and thus the very "American way of life".

Vale ressaltar que, quando a narrativa da "ameaça" é reverberada por acadêmicos, personalidades midiáticas, grupos nativistas, etc., ela pode ser considerada como mais uma visão, ainda que alternativa, da situação social e das suas condicionantes. Contudo, quando ela é replicada por autoridades estabelecidas (políticas, em regra), ela se torna um vetor fundamental da construção social da fronteira como algo absolutamente essencial para a garantia da segurança nacional. Disso para a adoção de medidas "excepcionais" é um pequeno passo.

É importante ressaltar que a construção social da fronteira também envolve a construção social da crise da fronteira. Nos termos de Rodriguez (1997: 228), além de ser essencial para a segurança nacional, a fronteira é apresentada como estando em um estado permanente de crise, sob o ataque de ondas de ilegais que permanentemente a tomam de assalto. Ora, sob tal perspectiva, a fronteira não deve ser apenas guardada - deve ser bloqueada. Daí a necessidade imperiosa de todas as medidas restricionistas, da militarização e da securitização dos imigrantes indocumentados. É a força dos movimentos nativistas em ação.

Para concluir, vale a pena examinar as palavras do autor sobre a percepção dos mexicanos como "ameaça" ao tecido social norte-americano:

Promoting perceptions of Mexicans or other national groups as "aliens", whether residing in the United States or in their own countries, adds to the social construction of the US-Mexico border by reinforcing the idea that these national groups are incompatible with, and even harmful to, US society and culture. It amounts to the villainization of the foreign born, which thus must be kept out with strict immigration policies and a strong southern border ${ }^{69}$ (RODRIGUEZ, 1997: 232).

No caso do vigilantismo, o seu ressurgimento pode ser visto como mais um "efeito colateral" do incisivo processo de securitização das migrações; notadamente, na região da fronteira Estados Unidos-México. Modernamente denominado de "neovigilantismo", esse movimento, formado por uma miríade de grupos civis que decidiram patrulhar a fronteira,

\footnotetext{
${ }^{69}$ Grifo nosso.
} 
ganhou destaque nacional a partir da fundação do mais famoso (e midiático) deles, o chamado Minutemen Project, que é um grupo civil de patrulha da fronteira fundado em outubro de 2004 por Jim Gilchrist e Chris Simcox, e que começou oficialmente suas atividades altamente repercutidas e veiculadas pela mídia - em $1^{\circ}$ de abril de 2005. Segundo um de seus membros, Grey Deacon, o grupo rejeita o termo imigrante "ilegal" ou "indocumentado". "They are not immigrants. They are ilegal aliens", afirma com veemência Deacon, que aproveita e tece obtusos comentários sobre Vicente Fox, comparando o presidente do México à época e seu governo com o Iraque de Saddam Hussein.

Segundo Roxanne Lynn Doty (2007: 114), professora da Universidade do Estado do Arizona, dado que a imigração de indocumentados tornou-se um assunto de alto relevo, com ampla cobertura da mídia, que insiste em chamar de "aliens" os imigrantes em tais condições, muitos indivíduos, tais como Deacon, são atraídos pelo "chamado ao dever". Ademais, a imigração de indocumentados tem sido relacionada a todo o tipo de coisa indesejada, tais como crimes, doenças, desastres ambientais e, após o Onze de Setembro, diretamente relacionada à questão da segurança nacional. Para a autora, que trabalha com a teoria de soberania e do político de Carl Schmitt em conjunto com o conceito de segurança societal desenvolvido pela Escola de Copenhague, a distinção que Schmitt faz entre amigo e inimigo e a questão da exceção são fundamentais para se compreender o fenômeno de tais grupos civis de patrulha da fronteira e o movimento anti-imigrante, em geral. Ademais, o conceito de segurança societal ajuda a entender o senso de emergência e a necessidade de medidas extraordinárias para garantir a sua sobrevivência enquanto entidade (seja esta a nação, um grupo étnico ou um grupo religioso). Destarte, a insegurança societal está no centro das preocupações dos grupos civis de patrulha, que enxergam a fronteira como algo extremamente vulnerável, além da ameaça que as populações de imigrantes residentes nos EUA (notadamente os indocumentados) representam para a nação (DOTY: 2007, 116). Eles fazem uma clara distinção entre o "amigo" e o "inimigo", além de tomarem medidas excepcionais para a proteção da identidade nacional dos EUA. Contudo, contrariando a teoria de securitização, tais medidas não são tomadas pelas elites, mas sim por pessoas comuns, que tomam a dianteira do processo e securitizam a questão por conta própria, baseadas nas suas percepções de ameaça. Ora, ao construírem socialmente o inimigo através de suas práticas (discursos, slogans, etc.), eles podem o apresentar como uma grande ameaça à ordem social, autorizando e justificando a adoção e o emprego de "medidas excepcionais" de modo a tentarem neutralizar a ameaça constituída (DOTY: 2009, 12). 
Outro grupo, mais antigo que o Minutemen mas bem menos midiático, o chamado Ranch Rescue, tem suas origens no ano de 2000, em Arlington (Texas), tendo sido formado por Jack Foote e um razoável grupo de pessoas, todos inspirados pelas épicas histórias do rancheiro Roger Barnett, que se gaba do fato de ficar constantemente vigiando a fronteira, já tendo efetuado (é o que alega) a "prisão civil" de mais de 12.000 indocumentados desde 1996. O seu procedimento padrão consiste em vigiar a fronteira e, caso note algum indocumentado atravessando-a, sai em seu encalço e o "prende", mantendo-o cativo até que a Border Patrol assuma a custódia do mesmo (DOTY: 2007, 119).

É curioso verificar que a crença na Reconquista, uma das mais fantasiosas lendas propagadas pela narrativa da "ameaça latina", é algo bastante comum entre as pessoas que se engajam nos grupos civis de patrulha da fronteira, além de creditarem toda a sorte de problemas (crime, drogas, etc.) à presença em solo americano dos indocumentados. Segundo o próprio Gilchrist (apud DOTY: 2007, 122): "From what I have seen in videos, to me there is a clear and present danger of insurrection, sedition and sucession by those who buy into the fact that this really is Mexico's territory and doesn't belong to the United States and should be taken back".

Por derradeiro, sabe-se que a securitização das migrações, notadamente no pós-Onze de Setembro, desempenhou um papel relevante no sentido de legitimar estes grupos aos olhos da população. Segundo uma pesquisa de abril de 2005, logo após a primeira ação dos Minutemen, 57\% da população do Arizona declarou seu apoio a eles. Ao mesmo tempo, a cobertura da mídia acerca das ações destes grupos neovigilantes e de organizações antiimigração cresceu após o Onze de Setembro, assim como o número de projetos de lei e iniciativas legislativas no sentido de se restringir ainda mais os fluxos migratórios, sendo que a conexão entre imigração e segurança nacional informa a base da quase totalidade dos grupos anti-imigração e neovigilantes existentes (DOTY: 2007, 123).

\subsubsection{Novos tempos, velhos inimigos: a fronteira e o estado de exceção}

Passados mais de um século e meio do estabelecimento oficial da fronteira Estados Unidos-México, nem a questão da segurança da fronteira, nem a política migratória, foram resolvidas de um modo a contemplar minimamente os interesses de ambas as partes. Os imigrantes indocumentados de origem mexicana continuam sendo o "velho inimigo", o bode expiatório perfeito para todas as mazelas que atingem os EUA; o inimigo conveniente e sempre à mão, pronto a ser imolado nos altares do racismo, do classismo, da xenofobia e, 
mais recentemente, da questão societal. Afinal, constituem uma verdadeira e ampla ameaça aos interesses e valores norte-americanos, muito embora sua força de trabalho seja o objeto do desejo de empresários estabelecidos nos EUA pouco interessados em prover garantias trabalhistas ou mesmo de remunerar adequadamente seus trabalhadores; seja nos campos, seja nas cidades.

Contudo, como se a vida dos indocumentados não fosse precária o suficiente, no pósOnze de Setembro não apenas as suas vidas, mas a de todos os imigrantes residentes em solo americano foi tornada muito mais difícil, dado o estado de exceção permanente que se consolidou nos Estados Unidos, outrora um grande defensor das liberdades e garantias civis.

Giorgio Agamben (2012: 13) esclarece, com propriedade, que "o estado de exceção tende cada vez mais a se apresentar como o paradigma de governo dominante na política contemporânea". Situando-se entre a democracia e o absolutismo, o estado de exceção é a regra diante da atual "guerra civil mundial". Assim colocado, ele continua:

O significado imediatamente biopolítico do estado de exceção como estrutura original em que o direito inclui em si o vivente por meio de sua própria suspensão aparece claramente na "military order", promulgada pelo presidente dos Estados Unidos no dia 13 de novembro de 2001, e que autoriza a 'indefinite detention' e o processo perante as 'military comissions' (não confundir com os tribunais militares previstos pelo direito da guerra) dos não cidadãos suspeitos de envolvimento em atividades terroristas (AGAMBEN: 2012, 14).

Pelo mesmo caminho, ou seja, pelo estado de exceção transita a maior parte das legislações e políticas destinadas a reforçar os controles migratórios dos EUA nas fronteiras terrestres (em especial, na com o México), além das políticas de vigilância e controle impostas aos imigrantes em solo americano, sejam estes legais ou "ilegais". Some-se a isso todas aquelas que se referem ao terrorismo ou a "guerra ao terror", que atingem indiscriminadamente toda a população norte-americana, restringindo seus direitos, liberdades e garantias civis em nome da segurança nacional e será possível vislumbrar o sombrio panorama político que se consolidou. O Patriot Act, examinado anteriormente, é o exemplo mais bem acabado deste novo tipo de legislação.

Pertence a Carl Schmitt a tentativa mais rigorosa de se construir uma teoria acerca do estado de exceção, continua Agamben (2012: 53-54), notadamente em suas obras sobre a ditadura e a teologia política que, embora escritas nos anos 1920, acabaram como que se tornando "proféticas", podendo ser aplicada a determinados momentos históricos, bastante críticos e, infelizmente, ao momento atual. O iustitium (literalmente "suspensão do direito"), 
instituto singular do Direito Romano, pode ser considerado o arquétipo do estado de exceção, posto que, quando invocado, suspendia não apenas a administração da justiça, mas do direito enquanto tal (2012: 68). Esta é, sem dúvida, a essência do estado de exceção que se instalou como paradigma não apenas da política contemporânea mas, em especial, do governo dos EUA, que logrou subsumir todas as questões que lhe são particularmente sensíveis e conflitivas ao imperativo da segurança nacional, tomado como o grande norte da nação e que justifica, em uma escala sem precedentes, a adoção de "medidas excepcionais" no trato de diversas questões as quais - obviamente - na sua grande maioria não possuem uma conexão real com a questão da segurança nacional. Contudo, no plano do discurso, elas podem ser perfeitamente justificadas, ainda mais face a uma audiência fragilizada e extremamente insegura. E é na região da fronteira Estados Unidos-México que o estado de exceção melhor se consolidou.

Na opinião de Jef Huysmans (2008), da Open University, o jargão da exceção se tornou a peça central nas atuais políticas de insegurança da Europa e dos Estados Unidos, aplicando-se, muito sagazmente, nas atuais políticas de controle de fronteira. Pode-se afirmar que, na luta entre o Direito e a Política, a grande perdedora foi a Justiça e, na esfera da fronteira, formou-se uma espécie de "vácuo legal" onde as normas tradicionais foram afastadas, o Direito esquecido, e a Política dominada pelo conceito do excepcionalismo; vale dizer, dirigida pelo idioma da exceção. Encerrando esta breve discussão, tem-se que, para Huysmans (2008: 180-181), ler a atual realidade da questão política e da segurança como se fossem questões de excepcionalismo pode acabar engedrando o risco de se reproduzir um “jargão" que cria conceitos sobre o político os quais, na melhor das hipóteses, marginaliza e, na pior delas, elimina; afasta da visão a categoria que, no moderno pensamento político, tem sido um componente essencial da prática política democrática. 


\section{Considerações finais}

Este trabalho de pesquisa teve por objetivo analisar a dinâmica da securitização dos fluxos migratórios no contexto da fronteira Estados Unidos-México; em especial, o caso dos imigrantes indocumentados de origem mexicana, que são o alvo primário das práticas securitizantes, no período compreendido entre os anos de 1978 - que corresponde ao início da aplicação da Doutrina do Conflito de Baixa Intensidade na região da fronteira e para o controle dos fluxos migratórios tidos como "ilegais" - e o de 2009, que corresponde ao último ano do governo de George W. Bush, ainda que o seu mandato tenha expirado a 20 de janeiro deste mesmo ano.

Para tanto, foi empregado o arcabouço teórico desenvolvido pela Escola de Copenhague; em especial, a teoria de securitização e o conceito de segurança societal, de tal sorte a se compreender a dinâmica da securitização e o modo através do qual estes imigrantes foram constituídos enquanto verdadeira "ameaça" ao tecido social norte-americano; à identidade nacional de seu povo.

O problema de pesquisa enfrentado foi formulado nos seguintes termos: quais são as condicionantes do processo de securitização no caso em tela? Em outras palavras: como se deu a securitização? Quais foram os atores, as forças e os fatores que, em seus respectivos níveis, interagiram no sentido de promover a securitização da questão migratória apresentada?

A hipótese adotada postulava que tal processo possui profundas raízes históricas e, a despeito de ser formalmente ancorado na questão da segurança societal, congrega outros elementos que o constituíram historicamente (racismo, por exemplo). Assim colocado, tem-se que a fronteira é o locus por excelência da construção da significação e das identidades; do "nós" e "eles" e, no caso da fronteira Estados Unidos-México, da "civilização" e "barbárie".

De fato, ao concluir o presente trabalho, restou corroborada tal hipótese, com alguns acréscimos e refinamentos. Descobriu-se que, além do racismo que alimentava os conflitos logo nos primeiros dias do estabelecimento da fronteira, a questão de classe também se colocava, sendo que tanto o racismo quanto o classismo figuravam na origem dos conflitos entre os "americanos" (anglo-saxônicos) e os mexicanos (os "non-whites"), seja na linha de fronteira, seja no território norte-americano, onde o mexicano já era visto como "indesejável". Assim posto, as práticas de segregação e exclusão tinham como destinatário final o mexicano "étnico". 
A progressiva militarização da fronteira, primeiro para "pacificar" a região, depois para manter o controle sobre os fluxos migratórios, também contribuiu, em muito, para tais processos, além de formatar padrões de significação e identificação. Ao norte, os civilizados; ao sul, os bárbaros. E esta dicotomia, ainda que tenha se metamorfoseando ao longo do tempo, não perdeu as suas características essenciais.

A segregação racial e a vilificação do "mexicano étnico"; seja este um imigrante indocumentado em busca de emprego, seja um cidadão mexicano-americano pobre, acabou sendo, posteriormemte, absorvida no plano discursivo pela ideia da "ameaça societal", ou seja, tanto a questão étnico-racial quanto a questão de classe foram entranhadas no discurso da ameaça societal que, com o apoio da "narrativa da ameaça", se disseminou amplamente, construindo a imagem do imigrante indocumentado como sendo uma "grave ameaça à sociedade norte-americana". Logo, ele deve ser combatido na fronteira, de modo a evitar que ingresse no território dos EUA e contribua para o esgarçamento do tecido social norteamericano. Isso tudo pode parecer uma grande obra fantasiosa; contudo, lamentavelmente esse tipo de mentalidade, sempre acompanhado de práticas restritivas, é o que sustenta o processo de securitização.

No caso do objeto referente, já está claro que é a identidade nacional norte-americana, tomada sob uma perspectiva puramente essencialista. O speech act, apesar da variedade de formas apresentadas ao longo do trabalho, sempre está acorado na "narrativa da ameaça". A audiência, primordialmente, é a população norte-americana, branca e que habita a região da fronteira. De modo complementar, a população dos estados fronteiriços. Ambas costumam responder bem a agressivas retóricas anti-imigração e, mais ainda, anti "illegal aliens", notadamente em tempos de crise econômica ou de "guerra ao terror", que é o caso atual.

Por fim, os agentes securitizantes são múltiplos, variando de acadêmicos a políticos, de personalidades midiáticas a grupos nativistas. Entretanto, em regra tais agentes pertencem a alguma determinada elite; política, acadêmica, etc. $\mathrm{O}$ "ponto fora da curva" nesse sentido, foi verificado quando do exame do ressurgimento do nativismo e do chamado "neovigilantismo", cujos agentes securitizantes são pessoas aparentemente comuns, que decidem por bem tomar a dianteira no combate aos "ilegal aliens" na região da fronteira.

Desse modo, os mexicanos "étnicos" que se tornaram imigrantes indocumentados passaram por um longo processo histórico de construção da sua identidade a partir do território dos EUA, ou seja, inicialmente, eram vistos como "non-whites" e, com o correr do tempo, foram se transformando, até alcançarem o status atual de "inimigos", fomentado por 
um intenso processo processo de securitização e com a retórica da "guerra ao terror" como pano de fundo.

Por fim, vale destacar que o trabalho de pesquisa efetuado revelou uma tendência histórica, que foi identificada e classificada, para fins de análise. Desse modo, entende-se que a securitização se deu em "ondas", por assim dizer, que foram se acumulando como que em camadas, institucionalizando o processo e tornando cada vez mais difícil a sua reversão.

A denominada "primeira onda de securitização", por assim dizer, além de seus elementos tradicionais, teve a sua materialidade garantida pela aplicação da Doutrina do LIC para a questão da imigração ilegal - o que gerou a militarização e o recrudescimento das políticas - e teve no Immigration and Naturalization Service (INS) o centro nervoso de todas as suas operações.

Já a "segunda onda de securitização" foi muito mais militarizada e midiática que a anterior, tendo desviado os fluxos de imigrantes ilegais para áreas mais remotas, hostis e extremamente perigosas, o que contribuiu para o aumento das mortes de imigrantes durante a dura travessia. Outro ponto a destacar foi o aumento expressivo no uso de equipamentos eletrônicos de última geração, destinados a reforçar as capacidades de controle e vigilância da Border Patrol, além da institucionalização de práticas (notadamente, a militarização) que, não raro, remontam aos primeiros dias da fronteira, tornando indisfarçável o seu caráter ostensivamente segregacionista, racista, classista e xenófobo.

Por fim, a "terceira onda de securitização", por assim dizer, tomou forma no pós-Onze de Setembro, incorporando de vez a questão terrorista na agenda de segurança da fronteira. $\mathrm{O}$ fato da questão migratória ter saído da esfera do INS (que foi dissolvido em 2003) e passado para o recém-criado Departamento de Segurança Interna (Department of Homeland Security) representa a consolidação; o ápide da securitização das migrações em um nível nunca antes atingido, dado que, de agora em diante, o problema migratório não é mais uma questão meramente política ou de viés criminal; ele é um típico problema de segurança nacional.

Encerrando a discussão, faz-se necessário esclarecer que, em tempo algum, houve a menor intenção de esgotar o assunto - o que seria um misto de ingenuidade com tola pretensão - dadas a alta complexidade do tema e os limites materiais se para trabalhar o assunto. Simplesmente buscou-se fazer uma singela reflexão sobre a problemática apresentada, deixando em aberto algumas questões que podem vir a ser trabalhadas futuramente, tais como a relativa ao estado de exceção e a progressiva supressão de direitos, garantias e liberdades civis não apenas nos EUA, mas por todo o globo, em nome de uma segurança nacional definida em termos cada vez mais vagos, imprecisos e ambíguos. A 
interação entre forças estatais e privadas de segurança para o gerenciamento, vigilância e controle da fronteira também sucita questões instigantes e complexas. Contudo, isso fica para o futuro. No momento, a despeito das imensas dificuldades, o que se pode esperar é que o retorno a normalidade e a desecuritização da questão migratória, cedo ou tarde, acabe ocorrendo, de modo a que o imigrante indocumentado possa ser tratado simplesmente como um ser humano, e não como inimigo de Estado. Porém, lamentavelmente, as chances disso ocorrer, ainda que no longo prazo, são um tanto quanto remotas. 


\section{Referências bibliográficas}

\section{Bibliografia utilizada}

ACKLESON, Jason. "Constructing Security on the US-Mexico Border”. In: Political Geography, Vol. 24, No. 2 (2005), p. 165-184.

AGAMBEN, Giorgio. Estado de Exceção. 2a ed. São Paulo: Boitempo, 2012.

ANDERSON, Benedict. Comunidades Imaginadas - Reflexões sobre a Origem e Difusão do Nacionalismo. São Paulo: Companhia das Letras, 2008.

ANDREAS, Peter. Border Games: Policing the US-Mexico Divide. Ithaca: Cornell University Press, 2009.

ASTOR, Avi. "Unauthorized Immigration, Securitization and the Making of Operation Wetback". In: Latino Studies (2009) 7, p. 5-29. Disponível em: <http://www.palgravejournals.com/lst/journal/v7/n1/pdf/lst200856a.pdf>. Último acesso em 02/07/2011.

BALDWIN, David A. The Concept of Security. In: Review of International Studies, Vol. 23, No. 1 (Jan., 1997), p. 05-26.

BAUMAN, Zygmunt. Identidade: Entrevista a Benedetto Vecchi. Rio de Janeiro: Zahar, 2005.

BERCOVITCH, Sacvan. The American Jeremiad. Madison: University of Wisconsin Press, 1978.

BUCHANAN, Patrick. State of Emergency: The Third World Invasion and Conquest of America. New York: St. Martin's Press, 2006.

BUZAN, Barry. People, States, and Fear - An Agenda for International Security Studies in the Post-Cold War Era. $2^{\text {nd }}$ ed. Boulder: Lynne Rienner, 1991.

; HANSEN, Lene. The Evolution of International Security Studies. New York:

Cambridge University Press, 2010. 
; WAEVER, Ole. Macrosecuritisation and Security Constellations: reconsidering scale in securitisation theory. In: Review of International Studies, Vol. 35, No. 2 (Apr., 2009), p. 253-276.

; WAEVER; Ole. Regions and Powers - The Structure of International Security. New York: Cambridge University Press, 2003.

; WAEVER; Ole. Slippery? Contradictory? Sociologically Unteneable? The Copenhagen School replies. In: Review of International Studies, Vol. 23, (1997), p. 241250.

; WAEVER; Ole; WILDE, Jaap de. Security - A New Framework for Analysis. Boulder: Lynne Rienner, 1998.

CAMÍN, Héctor Aguilar; MEYER, Lorenzo. À Sombra da Revolução Mexicana - História Mexicana Contemporânea, 1910-1989. São Paulo: Edusp, 2000.

CHACÓN, Justin Akers; DAVIS, Mike. No One is Illegal - Fighting Racism and State Violence on the US-Mexico Border. Chicago: Haymarket Books, 2006.

CHAVEZ, Leo R. The Latino Threat - Constructing Immigrants, Citizens, and the Nation. Stanford: Stanford University Press, 2013.

D'APPOLLONIA, Ariane Chebel. Frontiers of Fear - Immigration and Insecurity in the United States and Europe. Ithaca: Cornell University Press, 2012.

DEBORD, Guy. A Sociedade do Espetáculo - comentários sobre a sociedade do espetáculo. Rio de Janeiro: Contraponto, 2007.

DERIAN, James Der. The Value of Security: Hobbes, Marx, Nietzsche, and Baudrillard. In: LIPSCHUTZ, Ronnie D. (ed.). On Security. New York: Columbia University Press, 1995, p. 24-45.

DICKENS, Charles. A Tale of Two Cities. London: Penguin Books, 1994.

DOTY, Roxanne Lynn. States of Exception on the Mexico-US Border: Security, "Decisions", and Civilian Border Patrols. In: Intenational Political Sociology, (2007), 1, 113-137. 
DOTY, Roxanne Lynn. The Law Into Their Own Hands - Immigration and the Politics of Exceptionalism. Tucson: The University of Arizona Press, 2009.

DUNN, Timothy J. Blockading the Border and Human Rights - The EI Paso Operation that Remade Immigration Enforcement. Austin: University of Texas Press, 2009.

DUNN, Timothy J. The Militarization of the US-Mexico Border (1978-1992) - LowIntensity Conflict Doctrine Comes Home. Austin: CMAS Books, 1997.

FEARGIN, Joe R. "Old Poison in New Bottles: The Deep Roots os Modern Nativism”. In: PEREA, Juan F. (ed.). Immigrants Out! - The New Nativism and the Anti-Immigrant Impulse in the United States. New York: New York University Press, 1997, p. 13-43.

FOUCHER, Michel. Obsessão por Fronteiras. São Paulo: Radical Livros, 2009.

FUENTES, Carlos. La Frontera de Cristal - Una Novela en Nueve Cuentos. Madrid: Alfaguara, 1996.

GANSTER, Paul; LOREY, David E. The US-Mexican Border into the Twenty-First Century. Lanhan: Rowman \& Littlefield Publishers, Inc., 2008.

GELLNER, Ernest. Nations and Nationalism. Ithaca: Cornell University Press, 2008.

HABERMAS, Jürgen. The Structural Transformation of the Public Sphere. Cambridge: MIT Press, 1986.

HOBBES, Thomas. Leviatã. São Paulo: Martins Fontes, 2008.

HOBSBAWN, Eric J. Nações e Nacionalismo desde 1780 - Programa, mito e realidade. Rio de Janeiro: Paz e Terra, 2011.

HUNTINGTON, Samuel P. O Choque de Civilizações e a Recomposição da Ordem Mundial. Rio de Janeiro: Objetiva, 1997.

"The Hispanic Challenge". In: Foreign Policy Journal Quarterly, Spring, 2004. Disponível em: $<$ http://www.theatlantic.com/issues/96nov/immigrat/kennedy.htm >. Último acesso em: 16/05/2011. 
. "The Special Case of Mexican Immigration: Why Mexico is a Problem". In:

American Enterprise, december, p. 20-22, 2000.

. Who Are We? The Challenges to America's National Identity. New York:

Simon \& Schuster, 2005.

HUYSMANS, Jef. The Jargon of Exception - On Schmitt, Agamben and the Absence of Political Society. In: International Political Sociology (2008), 2, 165-183.

KISSINGER, Henry. Diplomacy. New York: Simon \& Schuster, 1994.

KLARE, Michael T. The Interventionist Impulse: US Military Doctrine for Low-Intensity Warfare. In: KLARE, Michael T.; KORNBLUH, Peter (eds.). Low-Intensity Warfare: Counterinsurgency, Proinsurgency, and Antiterrorism in the Eighties. New York: Pantheon Books, 1988, p. 49-79.

LEVARIO, Miguel Antonio. Militarizing the Border - When Mexicans Became the Enemy. College Station: Texas A\&M University Press, 2012.

MASSEY, Douglas S.; PREN, Karen A. Unintended Consequences of US Immigration Policy: Explaining the Post_1965 Surge from Latin America. In: Population and Development Review, Vol 38, No. 1 (2012), p. 01-29.

McSWEENEY, Bill. Identity and Security: Buzan and the Copenhagen School. In: Review of International Studies, Vol. 22, (1996), p. 81-93.

MORGAN, Kristi L. Evaluating Guest Worker Programs in the U.S.: A Comparison of the Bracero Program and President Bush's Proposed Immigration Reform Plan. In: Berkeley La Raza Law Journal, Vol. 15, Issue 2 (Fall 2004), p. 125-144.

NEVINS, Joseph. Operation Gatekeeper and Beyond - The War on "Illegals" and the Remaking of the US-Mexico Boundary. New York: Routledge, 2010.

NGAI, Mae. Impossible Subjects: Illegal Aliens and the Making of Modern America. Princeton: Princeton University Press, 2004.

RENAN, Ernest. What is a Nation? In: BHABHA, Homi K. (ed.). Nation and Narration. London: Routledge, 2006, p. 09-22. 
RODRIGUEZ, Néstor P. "The Social Construction of the US-Mexico Border". In: PEREA, Juan F. (ed.). Immigrants Out! - The New Nativism and the Anti-Immigrant Impulse in the United States. New York: New York University Press, 1997, p. 223-243.

ROE, Paul. Societal Security. In: COLLINS, Alan (ed.) Contemporary Security Studies. New York: Oxford University Press, 2010.

SCHLESINGER, Jr., Arthur M. The Disuniting of America - Reflections on a Multicultural Society. New York: WW Norton \& Company, 1998.

SEMPRINI, Andrea. Multiculturalismo. Bauru: EDUSC, 1999.

SMITH, Gladdis. The Last Years of the Monroe Doctrine (1945/1993). New York: Hill and Wang, 1994.

ST. JOHN, Rachel. Line in the Sand - A History of the Western US-Mexico Border. Princeton: Princeton University Press, 2013.

TODOROV, Tzvetan. O Medo dos Bárbaros - Para Além do Choque de Civilizações. Petrópolis: Vozes, 2010.

US Army. US Army Operational Concept for Special Operations Forces. In: Draft of internal US Army training document, 1983.

US Border Patrol. Border Patrol Strategic Plan: 1994 and Beyond (National Strategy). Washington DC, US Border Patrol, july 1994.

US Comission on Immigration Reform. Staff Report on Border Law Enforcement and Removal Initiatives in San Diego, California. Washington, DC, november 1995.

VELÁZQUEZ, Rafael; SCHIAVON, Jorge. La Iniciativa Mérida en el Marco de la Relación México-Estados Unidos. México, D.F.: Centro de Investigación y Docencia Económicas (CIDE), Documento de Trabajo n. 186, julio de 2009.

WAEVER, Ole, et al. Identity, Migration, and the New Security Agenda in Europe. London: Pinter Publishers, 1993. 
WEINTRAUB, Sidney. Unequal Partners: The United States and Mexico. Pittsburgh: University of Pittsburgh Press, 2010.

WALT, Stephen M. The Renaissance of Security Studies. In: International Studies Quarterly, Vol. 35, No. 2 (Jun., 1991), p. 211-239.

WOLFERS, Arnold. "National Security" as an Ambiguous Symbol. In: Political Science Quarterly, Vol. 67, No. 4 (Dec., 1952), p. 481-502.

Bibliografia consultada

ALDEN, Edward. The Closing of the American Border - Terrorism, Immigration and Security since 9/11. New York: Harper Perennial, 2009.

ANDREAS, Peter. A Tale of Two Borders: The US-Mexico and US-Canada Lines After 9-11. The Center for Comparative Immigration Studies. University of California, San Diego. Working Paper 77. May 2003.

BHAGWATI, Jagdish. Em Defesa da Globalização - Como a Globalização está Ajudando Ricos e Pobres. Rio de Janeiro: Elsevier, 2004.

BALZACQ, Thierry. The Three Faces of Securitization: political agency, audience and context. In: European Journal of International Relations, Vol. 11, No. 2 (2005), p. 171-201.

BAUMAN, Zygmunt. Globalização: As Consequências Humanas. Rio de Janeiro: Zahar, 1999.

BHABHA, Homi. O Local da Cultura. $2^{\circ}$ ed. Belo Horizonte: Editora UFMG, 2013.

BIGO, Didier. Security and Immigration: Toward a Critique of the Governmentality of Unease. In: Alternatives, Vol. 27 (2002), Special Issue, 63-92.

BRONK, Christopher; PAYAN, Tony. Developing the US-Mexico Border Region for a Prosperous and Secure Relationship - Managing the US-Mexico Border: Human Security and Techology. Binational Research Paper. James A. Baker III Institute for Public Policy. Rice University. April, 2009. 
CAMPBELL, David. Writing Security - United States Foreign Policy and the Politics of Identity. Minneapolis: Univesity of Minnesota Press, 1998.

EMMERS, Ralf. Securitization. In: COLLINS, Alan (ed.) Contemporary Security Studies. $2^{\text {nd }}$ ed. New York: Oxford University Press, 2010, p. 136-151.

FUENTES, Carlos. "Huntington and the Mask of Racism”. In: New Perspectives Quarterly, Vol. 21, No. 2, (Spring, 2004), p. 77-81.

. O Espelho Enterrado: reflexões sobre a Espanha e o Novo Mundo. Rio de Janeiro: Rocco, 2001.

HALL, Stuart. Identidade Cultural na Pós-modernidade. $11^{\text {a }}$ ed. São Paulo: DP\&A Editora, 1992.

HOLLINGER, David A. Postethnic America - Beyond Multiculturalism. New York: Basic Books, 2000.

KATZENSTEIN, Peter J. "Walls between 'Those People'? Contrasting Perspectives on World Politics" - Presidential Address delivered before the American Political Science Association, Toronto, 2009. In: Perspectives on Politics, Vol. 8, No. 1 (Mar., 2010), p. 11-25.

MARIL, Robert Lee. The Fence - National Security, Public Safety, and Illegal

Immigration along the US-Mexico Border. Texas: Texas Tech University Press, 2011.

MÁRMORA, Lelio. Las Políticas de Migraciones Internacionales. Buenos Aires: Paidós, 2004.

MASSEY, Douglas S.; DURAND, Jorge; MALONE, Nolan J. Beyond Smoke and Mirrors - Mexican Immigration in a Era of Economic Integration. New York: Russel Sage Foundation, 2003.

McSWEENEY, Bill. Durkheim and the Copenhagen School: a response to Buzan and Waever. In: Review of International Studies, Vol. 24, No. 1 (Jan., 1998), p. 137-140.

MORSE, Richard M. O Espelho de Próspero - Cultura e Idéias nas Américas. São Paulo: Companhia das Letras, 2000. 
PAYAN, Tony. The Three US-Mexico Border Wars - Drugs, Immigration and Homeland Security. Westport: Praeger Security International, 2006.

SMITH, Anthony D. National Identity. Reno: University of Nevada Press, 1991.

Press, 2000.

Nations and Nationalism in a Global Era. Cambridge: Cambridge University

TAKAKI, Ronald. A Different Mirror - A History of Multicultural America. New York: Back Bay Books, 2008.

TICHENOR, Daniel J. Dividing Lines - The Politics of Immigration Control in America. Princeton: Princeton University Press, 2002.

WAEVER, Ole. Securitization and Desecuritization. In: LIPSCHUTZ, Ronnie D. (ed.). On Security. New York: Columbia University Press, 1995, p. 46-86.

WILLIAMS, Michael C. Words, Images, Enemies: Securitization and International Politics. In: International Studies Quarterly, Vol. 47, No. 4 (Dec., 2003), p. 511-531.

ZEA, Leopoldo. Discurso desde a Marginalização e a Barbárie. Rio de Janeiro: Garamond, 2005. 